Universidade de Brasília - UnB

Faculdade de Economia, Administração e Contabilidade - FACE

Programa de Pós-Graduação em Administração - PPGA

Mestrado Profissional em Administração - MPA

\title{
INOVAÇÃO EM SERVIÇOS E DESEMPENHO ORGANIZACIONAL: UMA NOVA ABORDAGEM DE AVALIAÇÃO AMBIENTAL PELO TCU
}

\author{
Carlos Eduardo Lustosa da Costa
}

Orientadora: Prof. ${ }^{\text {a }}$ Doutora Cristina Castro-Lucas

$$
\text { Brasília - DF }
$$




\section{INOVAÇÃO EM SERVIÇOS E DESEMPENHO ORGANIZACIONAL: UMA NOVA ABORDAGEM DE AVALIAÇÃO AMBIENTAL PELO TCU}

Carlos Eduardo Lustosa da Costa

Dissertação apresentada ao Curso de Mestrado Profissional em Administração da Universidade de Brasília (UnB), como requisito parcial para obtenção do grau de Mestre em Administração.

Orientadora: Professora Doutora Cristina Castro-Lucas

Brasília - DF 


\section{BANCA EXAMINADORA}

Orientadora: Professora Doutora Cristina Castro-Lucas

Universidade de Brasília

\section{Membro: Professor Doutor Claudio Vaz Torres \\ Universidade de Brasília}

Membro: Professora Doutora Elaine Maria Tavares Rodrigues Universidade Federal do Rio de Janeiro

Membro: Professora Doutora Eda Castro Lucas de Souza Universidade de Brasília

Brasília - DF 
Ao meu pai, o escritor e jornalista Lustosa da Costa, minha referência e, ao mesmo tempo, meu maior incentivador. 


\section{Agradecimentos}

Uma jornada repleta de desafios só é possível de ser realizada com êxito se contar com o apoio e a torcida de diferentes atores. Assim, gostaria de agradecer, primeiramente, a minha mãe, Veronica Lustosa da Costa, que, em nossas conversas diárias, sempre me carregava com palavras positivas e de otimismo, pedindo em suas orações o sucesso pessoal e profissional de seus filhos.

Agradeço a Paula, minha esposa, por ser o pilar fundamental que me garante tranquilidade e cuja compreensão e estímulo foram essenciais para esta trajetória.

A Deus que me deu o presente mais valioso da vida, o pequeno grande Heitor, a quem espero influenciar para que também busque constantemente o saber científico.

A minhas irmãs Raquel e Sara que concretizam a perpetuação da história de meu pai.

Ao meu tio e amigo, o professor Frederico Lustosa, por ter me avisado do mestrado e, principalmente, por suas valiosas contribuições.

À Professora Cristina Castro-Lucas que durante o processo de orientação me possibilitou enxergar novos temas sob outras perspectivas.

Aos Professores Claudio Torres, Eda Castro e Elaine Tavares pelas contribuições oferecidas que possibilitaram o aperfeiçoamento desta pesquisa.

Ao colega de turma, Daniel Sakita, que se transformou em um grande amigo, bem como aos demais companheiros do PPGA.

Ao amigo-irmão, Hugo Chudyson, cuja dedicação ao trabalho no TCU contribuiu para que me fosse possível conciliar a coordenação de uma auditoria com a elaboração desta pesquisa.

Por fim, agradeço também àqueles colegas do TCU que entrevistei pela disponibilidade e informações fornecidas. 
Devo agradecer a Deus todas as estações da vida que procurei viver plenamente. A velhice só encerra uma vantagem: a de a gente haver testemunhado muita coisa que os mais novos jamais verão.

Tirante isto, a experiência que nos atribuem é a soma dos erros que cometemos e que continuamos a repetir, sem imaginação nem criatividade. Repito, porém, que não tenho razões para me queixar da vida porque a vivi em plenitude e conforme cada uma de suas estações. Ainda hoje agradeço a Deus pelos livros que li, pelos que escrevi e publiquei, pela descendência que pus no mundo e está abrindo os próprios caminhos. 


\section{SUMÁRIO}

1 - INTRODUÇÃO.

1.1 OBJETIVO GERAL, OBJETIVOS ESPECÍfICOS E PERGUNTA DE PESQUISA.....

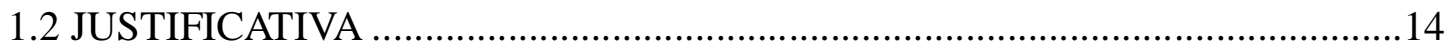

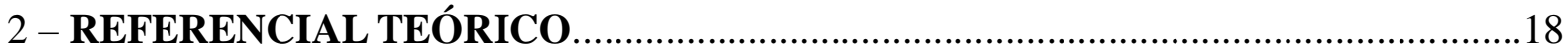

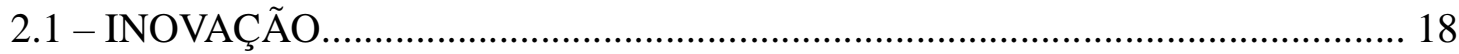

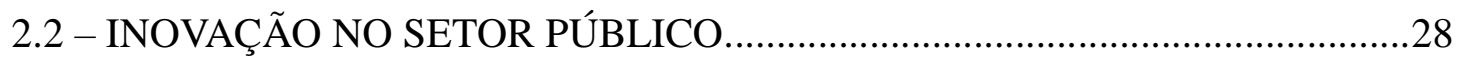

2.3 - DESEMPENHO NO SETOR PÚBLICO_..............................................................

2.4 - AVALIAÇÃO DE POLÍTICAS PÚBLICAS E O PAPEL DO TCU.....................40

3 - INDIMAPA

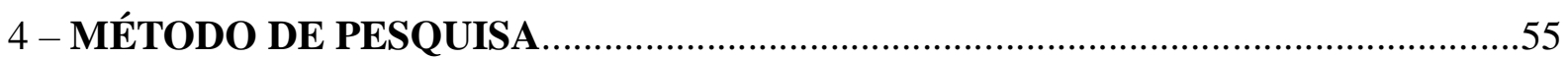

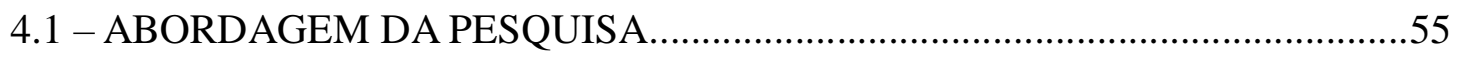

4.2 - AMOSTRA E DESCRIÇÃO DA PESQUISA.......................................................55

4.3 - PROCEDIMENTOS DE COLETA DE DADOS .............................................55

4.4 - PERFIL DE PARTICIPANTES NA ENTREVISTA............................................56

4.5 - ANÁLISE DAS ENTREVISTAS.................................................................

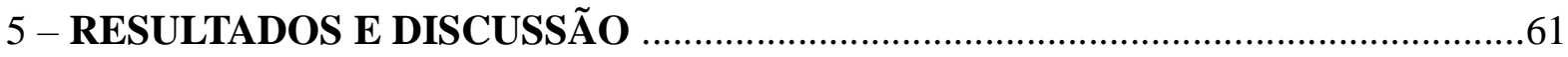

6 - CONCLUSÕES, RECOMENDAÇÕES E AGENDA DE PESQUISA ..........................93

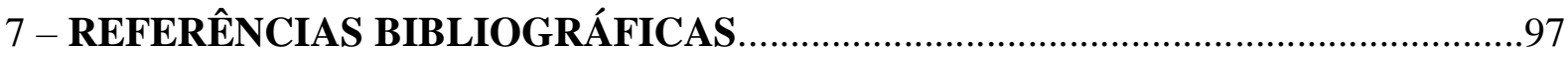

8 - APÊNDICE - INSTRUMENTO DE COLETA DE DADOS.........................................103

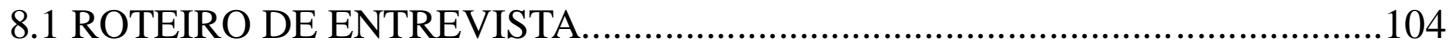




\section{LISTA DE QUADROS}

Quadro 1: Tipos de Inovação na visão Integradora. .23

Quadro 2: Indicadores de Implementação e de Gestão de Áreas Protegidas

Quadro 3: Perfil dos entrevistados. 56

Quadro 4: Exemplo de Matriz de Análise das auditorias .58

Quadro 5: Procedimentos metodológicos utilizados. .59

Quadro 6: Comparativo entre as auditorias coordenadas.

Quadro 7: Consolidação das respostas dos entrevistados: Indimapa segundo classificação de inovação. 84

Quadro 8: Matriz de Análise - Comparação entre auditorias e a Auditoria em Áreas Protegidas 86

\section{LISTA DE FIGURAS}

Figura 1: Modelo dos vetores que caracterizam os produtos do serviço.

Figura 2: Modelo conceitual de Walker, Damanpour e Devece .35

Figura 3: Quadro de Normativos. .46

Figura 4: Exemplo de gráfico de radar com indicadores do Indimapa .49

Figura 5: Modelo de inovação de serviços e desempenho organizacional no TCU. .53

\section{LISTA DE MAPAS}

Mapa 1: Indimapa Amazônia Brasileira. .50

Mapa 2: Indimapa América Latina. 


\section{LISTA DE ABREVIATURAS E SIGLAS}

Anop

CDB

COMTEMA

EFS

EPSIS

GESPÚBLICA

GIZ

INDIMAPA

INTOSAI

MEPIN

METT

OCDE

OLACEFS

ONU

PAMA

PIB

RAPPAM

SAI

TCE

TCU

TIC

$\mathrm{UE}$

WGEA
Auditoria de Natureza Operacional

Convenção das Nações Unidas sobre Diversidade Biológica

Comissão Técnica Especial de Meio Ambiente

Entidades de Fiscalização Superior

European Public Sector Innovation Scoreboard

Programa Nacional de Gestão Pública e Desburocratização

Deutsche Gesellschaft für Internationale Zusammenarbeit

(Agência Alemã de Cooperação Internacional)

Método de Avaliação da Implementação e da Gestão de Áreas Protegidas

International Organization of Supreme Audit Institutions

Medindo a inovação no setor público nos países nórdicos

Management Effectiveness Tracking Tool

Organização para Cooperação Econômica e Desenvolvimento

Organização Latino-americana e do Caribe de Entidades Fiscalizadoras

Superiores

Organização das Nações Unidas

Programa de Ação Mercosul Livre de Febre Aftosa

Produto interno bruto

Rapid Assessment and Prioritization of Protected Areas Management

Supreme Audit Institutions

Tribunal de Contas Estadual

Tribunal de Contas da União

Tecnologia da Informação e Comunicação

União Europeia

Working Group on Environmental Auditing 


\section{RESUMO}

O objetivo deste trabalho é analisar a relação entre inovação de serviços e desempenho organizacional no Tribunal de Contas da União (TCU) utilizando como objeto de estudo a ferramenta de avaliação denominada Indimapa. Trata-se de um novo instrumento de avaliação desenvolvido pelo TCU que utiliza indicadores e índices, os quais são visualizados em mapas georreferenciados e permitem um panorama da política pública analisada. Assim, na presente pesquisa foram estudados o Indimapa como fenômeno da inovação de serviços e a sua contribuição para o desempenho da organização, em especial quanto à comunicação dos resultados, à padronização na avaliação e ao monitoramento do objeto avaliado. Além disso, buscou-se identificar os produtos gerados e os benefícios decorrentes da utilização do Indimapa, com vistas a verificar se o método desenvolvido pode ser classificado como uma inovação de serviços e de que forma ele melhora o desempenho do Tribunal de Contas da União no processo de avaliação de políticas públicas. Para isso, foi utilizada a abordagem qualitativa, com a aplicação de roteiro de entrevista estruturada a servidores do TCU, pesquisa em base de dados e análise dos relatórios de auditoria. Os resultados apontaram que o Indimapa se caracteriza como uma inovação de serviços já que otimiza a forma de divulgação dos resultados e a consolidação de dados, além de tornar mais eficiente o processo de monitoramento. Portanto, espera-se que, a partir da identificação e análise das características do Indimapa, o presente trabalho contribua para os estudos em inovação de serviços no setor público e, consequentemente, para a melhoria do desempenho organizacional do TCU.

Palavras-chaves: Inovação de serviços; Desempenho, Avaliação de políticas públicas; TCU. 


\begin{abstract}
The objective of this paper is to analyze the relationship between services innovation and organizational performance in the Brazilian Court of Audit (TCU) using, for that, as a case study the evaluation tool called Indimapa. It is a new assessment tool developed by the TCU, which uses indicators and indices, which are displayed on geo-referenced maps and supply an overview of the public policy under analysis. Thus, in this research it has been studied the phenomenon Indimapa as services innovation and its contribution to organizational performance, especially related to the reporting of results, to standardize the assessment and to monitoring of the evaluated object. In addition, we intended to identify the products generated and the benefits arising from the use of Indimapa, in order to verify that the method developed can be classified as services innovation and how it improves organizational performance of the Brazilian Court of Audit in the evaluation process of public policies. For this, qualitative approach was used, besides search database and analysis in audit report. The results show that Indimapa can be defined as a services innovation since it optimizes the results divulgation and data consolidation, and make the monitoring process more efficient. Besides that, an application of structured interview was carried out. Therefore, it is expected that, from the identification and analysis of Indimapa features, this paper contributes to studies on innovation in services in the public sector and hence to improve TCU organizational performance.
\end{abstract}

Keywords: Services innovation, Performance, Public policies assessment, TCU. 


\section{INTRODUÇÃO}

A crescente demanda social por serviços públicos mais eficientes tem exigido diferentes respostas governamentais para atender aos anseios da população. Uma das formas de responder a esse desafio é por meio da utilização de inovações de cunho tecnológico, organizacional, gerencial e social (BEINARE; MCCARTHY, 2011; HALVORSEN, 2005; RØSTE, 2005).

A inovação apresenta-se como alternativa que contribui para o aperfeiçoamento de atividades do setor público e, consequentemente, para a melhoria da qualidade dos serviços oferecidos à população (VIGODA-GADOT; SHOHAM; SCHWABSKY; RUVIO, 2008). Nessa linha, Salazar e Holbrook (2004) destacam que no setor público a inovação é voltada para área de serviços uma vez que o poder público é essencialmente um fornecedor de serviços. Mulgan e Albury (2003) enfatizam que a inovação deve ser uma atividade essencial do setor público, pois contribui para melhoria do desempenho dos serviços públicos, para o incremento da eficiência das organizações, além de minimizar custos.

Os processos inovadores no setor de serviços contribuem para aprimorar o desempenho dos órgãos e entidades públicos, incrementando a qualidade e alavancando sua produtividade, fato que poderá se revestir em crescimento econômico e também em benefício social. Nesse sentido, é fundamental compreender melhor tais processos e sua relação com o desempenho organizacional, identificando, por exemplo, atividades de inovação com impacto no desempenho das organizações públicas e seus respectivos indutores de inovação.

O Manual de Copenhagen (2010) salienta que, embora existam barreiras para mensurar o impacto de práticas inovadoras no setor público, é possível sublinhar algumas manifestações de valor que podem surgir de inovações em serviços públicos. Nesse sentido, alguns fatores, apesar de também estarem presentes no setor privado, são mais almejados na esfera pública, como, por exemplo: a melhoria na transparência administrativa, o incremento da prestação de contas (accountability) e o fortalecimento do controle social.

Essas medidas buscam aumentar a efetividade de políticas públicas para que os serviços públicos prestados contem com maior qualidade e atendam equitativamente a sociedade, de tal sorte que se possa exercer um maior controle das ações governamentais. Pretende-se ainda que a forma da administração pública comunicar-se com a sociedade seja aperfeiçoada fazendo com que seja possível para o cidadão compreender como funciona a máquina pública.

Portanto, a inovação é percebida tanto no setor privado quanto no setor público sendo 
que neste o objetivo último que se deve buscar com a realização de práticas inovadores é servir melhor à sociedade, por meio da ampla oferta de serviços de qualidade que atendam de modo equitativo e transparente a todos os cidadãos. Assim, os valores almejados pela esfera privada e pelo poder público nem sempre são convergentes. Por isso, é preciso estabelecer mecanismos que sejam adequados à realidade do setor público, de forma que seja possível identificar ações e atividades que produzam melhorias no desempenho da administração pública e que permitam constatar e, quiçá, quantificar os benefícios advindos de medidas inovadoras, ou seja, as manifestações de valor.

Desse modo, a inovação constitui-se em uma atividade central tanto no setor público quanto no setor privado, o que leva ao aumento da capacidade de resposta dos serviços às necessidades locais e individuais. Assim, o serviço público necessita inovar a fim de melhorar a eficiência administrativa de suas atividades essenciais e o desempenho da máquina administrativa (SALAZAR; HOLBROOK, 2004).

Um dos atores responsáveis por avaliar o desempenho de instituições é o Tribunal de Contas da União (TCU) que, dentre suas atribuições de controle externo, realiza auditorias operacionais para avaliar políticas públicas com a finalidade de promover o aperfeiçoamento da gestão pública. Nesse tipo de avaliação, o TCU analisa a economicidade, eficiência, eficácia e efetividade de organizações, políticas públicas e programas governamentais em diferentes áreas, inclusive em objetos relativos à temática ambiental (TCU, 2010).

Assim como qualquer atividade, as auditorias precisam estar abertas a inovações que visem aprimorar seu processo de trabalho e ofereçam novos produtos. Nesse cenário, as avaliações da Corte de Contas devem buscar implementar novos procedimentos, ferramentas e técnicas de auditoria a fim de alcançar melhores resultados para o desempenho institucional.

Um exemplo da busca por mecanismos mais eficientes para o processo de trabalho das auditorias do TCU é a criação do Indimapa - método utilizado pelo controle externo para avaliação de uma política pública ambiental. Com efeito, trata-se de ferramenta elaborada para avaliar a gestão de unidades de conservação (UCs), as quais podem ser definidas como territórios estabelecidos pelo poder público para a proteção da biodiversidade.

$\mathrm{O}$ instrumento utiliza indicadores e índices que permitem classificar as UCs em três níveis de implementação e de gestão: vermelho (nível mais baixo), amarelo (nível intermediário) e verde (nível mais alto). Os resultados decorrentes da aplicação do método são visualizados por meio de mapas georreferenciados que, além de proverem uma análise individualizada da gestão das UCs, comunicam uma avaliação sistêmica dessa temática. 
Cumpre ressaltar ainda que a utilização de mapas georreferenciados facilita o monitoramento do TCU acerca da política pública de conservação da biodiversidade, uma vez que permitirá a comparação cronológica do objeto avaliado.

Nesse contexto e conforme será exposto ao longo deste trabalho, o Indimapa aparece como uma ferramenta nova que tem como característica, entre outros pontos, o potencial de analisar de maneira sistêmica e padronizada o objeto auditado, possibilitando obter um panorama da política pública avaliada, bem como fornecendo à sociedade uma comunicação mais acessível dos resultados obtidos.

Desse modo, esse instrumento poderá alterar a forma como vêm sendo conduzidas as auditorias sob a responsabilidade do TCU, contribuindo para a melhoria do desempenho organizacional e, consequentemente, para o processo de avaliação de políticas públicas pela Tribunal de Contas da União.

Assim, a pergunta de pesquisa do presente trabalho é: o Indimapa pode ser caracterizado como uma inovação de serviços, e, em caso positivo, de que forma ele influencia o desempenho organizacional do TCU?

Em decorrência da pergunta de pesquisa, tem-se que o objetivo geral consiste em verificar se o Indimapa pode ser caracterizado como uma inovação de serviços, e, em caso positivo, de que forma influencia o desempenho organizacional do TCU. Portanto, os objetivos específicos do trabalho são:

a) Identificar os indutores de inovação de serviços da ferramenta de avaliação ambiental (Indimapa);

b) Identificar a influência do Indimapa sobre a comunicação dos resultados das auditorias do Tribunal de Contas da União (TCU), sobre o processo de monitoramento e sobre a padronização na avaliação do objeto auditado no âmbito das auditorias do TCU;

c) Verificar se o Indimapa pode ser classificado como inovação de produto, inovação de comunicação, inovação organizacional e inovação de processo no Tribunal de Contas da União.

\section{2 - JUSTIFICATIVA}

O tema inovação tem sido objeto de estudo muito presente na literatura de negócios, pelo seu impacto no desempenho das organizações e pela geração de vantagem competitiva. No entanto, poucas pesquisas são realizadas no setor público sobre essa temática (WALKER; DAMANPOUR; DEVECE, 2010; JUNIOR; GUIMARÃES, 2012; MOREIRA; 
GUIMARÃES; CASTRO-LUCAS; ALBUQUERQUE, 2014).

Embora existam muitas experiências de inovação no setor público, tanto no exterior (BORINS, 2001; WILLIAMS, 2012) quanto no Brasil (FERREIRA, 2014), ainda são incipientes as pesquisas sobre inovação nos serviços públicos (SALAZAR; HOLBROOK, 2004; GALLOUJ; WINDRUM, 2009).

Segundo Salge (2010), a pesquisa em inovação tem se concentrado no setor privado, mais precisamente no setor industrial, algo que não se transfere linearmente para o setor público, mesmo que a inovação seja um elemento essencial para capacitar os governos para o enfrentamento de seus desafios.

É nessa conjuntura que a inovação vem ganhando importância como tema estratégico para a administração pública (MULGAN; ALBURY, 2003; WALKER, 2007; VIGODAGADOT; SHOHAM; SCHWABSKY; RUVIO, 2008), fazendo com que cada vez mais estudos se dediquem à análise deste fenômeno de forma empírica. Walker (2007) argumenta, porém, que a produção científica ainda se encontra em processo de consolidação e que, portanto, faz-se necessário que pesquisadores desenvolvam mais conhecimento sobre a natureza da inovação no serviço público.

Moreira, Guimarães, Castro-Lucas e Albuquerque (2014), em extensa e profunda pesquisa, mapearam o campo de estudo referente à inovação de serviços nos últimos 30 anos (1984-2014), com o objetivo de contribuir para a compreensão da trajetória histórica do tema, bem como apontar perspectivas para próximas pesquisas.

Nesse levantamento bibliométrico, por meio do exame do conteúdo de 209 pesquisas selecionadas em base de dados abertas, acerca de inovação de serviços, os autores identificaram que, do total de pesquisas realizadas entre 1984 e 2014, a maioria (74,2\%) foi publicada nos últimos sete anos, o que demonstra o crescente interesse pela área e o quão recente e relevante o tema é (MOREIRA; GUIMARÃES; CASTRO-LUCAS E ALBUQUERQUE, 2014).

Quando analisada a produção no tema "inovação no setor público", os pesquisadores constataram que a temática tem um aparecimento tardio no campo, já que até 2005 não foram identificadas pesquisas nessa área. Além disso, Moreira, Guimarães, Castro-Lucas e Albuquerque (2014) chamam a atenção para o fato de que a inovação no setor público, entre os temas avaliados, tem apenas $4 \%$ do total das ocorrências. Além disso, a inovação no setor público tem a menor contagem de todos temas avaliados e um crescimento fraco em termos de produção científica. 
Esse fato agrava-se quando realizada uma análise do uso da inovação para a avaliação de políticas públicas, já que, ao pesquisar tais termos nas bases de dados Scielo, Google Acadêmico, Spell, Jpart, nenhum resultado foi encontrado. Essas evidências reforçam a necessidade, do ponto de vista acadêmico, de estudar um campo que ainda se encontra em processo de consolidação no exterior e, principalmente, no Brasil.

A avaliação de políticas públicas também está sujeita a inovações que possam aperfeiçoar seu processo e oferecer novos produtos e/ou serviços. No Brasil, a atividade de avaliar políticas públicas é realizada por diversos atores, sejam governamentais ou não. Dentre eles, pode-se citar o Tribunal de Contas da União (TCU) que, por meio de auditorias operacionais (anop), analisa pontos referentes à economicidade, eficácia, eficiência e efetividade de instituições, ações governamentais e políticas públicas.

Portanto, ao buscar analisar a contribuição do Indimapa para as auditorias do TCU, a presente investigação, em função de sua relevância teórica, é justificada por realizar pesquisa num campo ainda em solidificação. Além disso, pretende-se verificar se o Indimapa pode ser considerado uma inovação no TCU. Nesse contexto, Koch e Haucknes (2005) e Junior e Guimarães (2012) destacam a necessidade de métodos adequados para medir inovação no setor público. Assim e tendo em vista a lacuna em relação ao tema "inovação no setor público aplicada à avaliação de políticas públicas", espera-se contribuir para a difusão de pesquisas sobre inovação de serviços no setor público brasileiro.

Cabe destacar também que a realização de ações inovadoras visando o aperfeiçoamento de processos de trabalho tem impacto no desempenho organizacional e, consequentemente, nos serviços prestados por uma instituição, seja pública ou privada (WALKER; DAMANPOUR; DEVECE, 2010). Desse modo, avaliar os serviços decorrentes da utilização do Indimapa poderá propiciar a evolução das auditorias do TCU, contribuindo ainda para a melhoria da política pública de conservação da biodiversidade. Ademais, buscase o aprimoramento da função de controle, atividade essencial de Estado, conforme preconizado pela Constituição Federal brasileira.

A realização da pesquisa para verificar a influência do Indimapa no TCU poderá auxiliar a instituição a aprimorar suas ações de controle por meio de uma atuação mais estratégica e ampla, além de oferecer à Corte de Contas uma ferramenta gerencial mais eficiente a qual permitirá um monitoramento a longo prazo da política pública de áreas protegidas. Adicionalmente, espera-se que a ferramenta sirva de base para auxiliar no processo de avaliação de outras políticas públicas. 
Já quanto à importância social, vale destacar que atividade de controle precisa oferecer meios adequados à sociedade para acompanhar o desempenho da Administração Pública, não se restringindo apenas à análise de malversação de recursos financeiros (LOUREIRO; ARANTES; COUTO; TEIXEIRA, 2010). Nesse sentido, a comunicação das informações de forma acessível, por meio de mapas georreferenciados por exemplo, fomenta o aumento da transparência administrativa e o incremento da prestação de contas (accountability), atributos cada vez mais almejados pelos governos nacionais (OCDE, 2005).

Por último, a fim de orientar a leitura desse documento, é preciso ressaltar que o trabalho está dividido em 5 partes, além desta introdução. Assim, em seguida, tratar-se-á do referencial teórico cujos temas são inovação de serviços no setor público e desempenho organizacional. Ainda nessa parte serão abordados a avaliação de políticas públicas e o papel do Tribunal de Contas da União. Em seguida, será descrito o objeto de estudo da presente pesquisa, o Indimapa. Logo após será apresentado o método utilizado para atingir os objetivos da presente pesquisa. Já a quinta parte desse documento traz os resultados obtidos, além de apresentar a discussão realizada com base no referencial teórico usado. Por último, na sexta parte são expostas as conclusões, recomendações e agenda de pesquisa. 


\section{2 - REFERENCIAL TEÓRICO}

O presente Capítulo está dividido em três seções. Inicialmente será abordada a inovação, com ênfase na inovação de serviços, seguida do panorama da Inovação no Setor Público. Na sequência, será discutido desempenho organizacional na esfera pública. Por fim, na terceira seção, discutem-se a Avaliação de Políticas Públicas e o Papel do TCU.

\subsection{INOVAÇÃO}

O conceito de inovação é bastante variado, dependendo, principalmente, do contexto onde é aplicado. Este termo é conhecido desde Adam Smith no século XVIII, que estudava a relação entre acumulação de capital e a tecnologia de manufatura, analisando conceitos relacionados à mudança tecnológica, divisão do trabalho e competição. Porém, foi somente a partir do trabalho de Joseph Schumpeter que se estabeleceu uma relação entre inovação e desenvolvimento econômico (GALLOUJ, 2007).

A contribuição de Schumpeter (SCHUMPETER, 1982) influenciou bastante as teorias da inovação. Seu argumento é de que o desenvolvimento econômico é conduzido pela inovação por meio de um processo dinâmico em que as novas tecnologias substituem as antigas, um processo por ele denominado "destruição criadora". Segundo Schumpeter (1934), inovações "radicais" engendram rupturas mais intensas, enquanto inovações "incrementais" dão continuidade ao processo de mudança. Assim, ele propôs uma lista de cinco tipos de inovação: $a$ ) introdução de novos produtos; $b$ ) introdução de novos métodos de produção; $c$ ) abertura de novos mercados; $d$ ) desenvolvimento de novas fontes provedoras de matériasprimas e outros insumos; e $e$ ) criação de novas estruturas de mercado em uma indústria.

Desse modo, uma perspectiva schumpeteriana tende a enfatizar a inovação como experimentos de mercado e a procurar mudanças amplas e extensivas que reestruturam fundamentalmente indústrias e mercados (OCDE, 2005). De acordo como o Manual de Oslo, a Economia da corrente dominante ou os neoclássicos veem a inovação em termos de criação de ativos e de experimentos de mercado. Nessa visão, a inovação é um aspecto da estratégia de negócios ou uma parte do conjunto de decisões de investimentos para criar capacidade de desenvolvimento de produto ou para melhorar a eficiência.

As elaborações de Schumpeter no início do século XX tiveram um impacto considerável no debate sobre transformações tecnológicas e desenvolvimento econômico (MEIRELLES, 2008). Segundo ele, os investimentos nas novas combinações de produtos e 
processos produtivos de uma empresa repercutem diretamente em seu desempenho financeiro, de modo que o moderno empresário capitalista deve desempenhar ao mesmo tempo um papel de liderança econômica e tecnológica. O comportamento empreendedor, com a introdução e ampliação de inovações tecnológicas e organizacionais nas empresas, constitui um fator essencial para as transformações na esfera econômica e seu desenvolvimento no longo prazo (GALLOUJ, 2002).

Entretanto, inovação não deve ser vista como um resultado final e conclusivo, e sim como um processo de resolução de problemas, no qual a aprendizagem e interações múltiplas entre os agentes possuem o papel principal (GALLOUJ, 2002). Além disso, uma inovação bem-sucedida é a criação e a implementação de novos processos, produtos, serviços e métodos de entrega que resulta em melhora significativa nos resultados de eficiência, efetividade ou qualidade (MULGAN; ALBURY, 2003). Para Sundbo e Gallouj (1998) elas podem ser distinguidas em cinco tipos - taxonomia genérica: 1. inovação de produto; 2 . inovação de processo; 3. inovação organizacional; 4. inovação de mercado; e 5. inovação ad hoc.

As inovações de produto, ao proverem alterações relevantes, envolvem bens e serviços totalmente novos ou significativamente melhorados. As inovações de processo estabelecem mudanças nos procedimentos necessários para produzir e distribuir o serviço. As inovações organizacionais são novas formas de organização ou de gestão, tais como a introdução de controle de qualidade etc. As inovações do mercado significam novos comportamentos no mercado (descoberta de novos segmentos de mercado, entrada em novos mercados, etc). Já a inovação ad hoc busca solução de um problema particular apresentado por um cliente. Em suma, pode-se afirmar que se adaptada a tipologia básica schumpeteriana pode ser utilizada neste contexto específico dos serviços, a despeito da complexidade intrínseca dos serviços.

Nesse sentido, Gallouj e Weinstein (1997) destacam que a análise da inovação no setor de serviços é complexa em função de dois fatores: a) a base da teoria de inovação desenvolveu-se sob o estudo de inovações tecnológicas em atividades de manufatura, b) é difícil medir e detectar mudanças nos serviços devido às propriedades específicas em suas atividades.

\section{Inovação de serviços}

Atualmente, o setor de serviços representa cerca de $80 \%$ do produto interno bruto (PIB) dos EUA e entre $60 \%$ e $80 \%$ do PIB das outras economias avançadas do mundo 
(CHESBROUGH, 2005). Assim, em função da relevante materialidade envolvida, é preciso analisar a inovação à luz dos serviços. Antes, porém, cabe abordar brevemente uma definição de serviço.

Para Zarifian (2001) serviço é uma organização e uma mobilização, o mais eficiente possível, de recursos para interpretar, compreender e gerar a mudança perseguida nas condições de atividade do cliente-usuário. Nesse contexto, a inovação de serviços deve visar o incremento da qualidade, a redução de custos de produção e a diminuição do tempo de desenvolvimento e prestação do serviço (KLEMENT, 2007).

Dessa forma, através da inovação, as empresas no ramo de serviços buscam atender às "exigências de eficiência e tempo de resposta dos consumidores, assim como aumentar sua produtividade, melhorar a qualidade do produto e, principalmente, diminuir o ciclo de projetos, no intuito de se manterem à frente da concorrência” (KLEMENT, 2007, p. 21).

Na visão de Lovelock e Wright (2004), serviços são atividades econômicas que criam valor e fornecem benefícios para clientes em tempos e lugares específicos, como decorrência da realização de uma mudança desejada ou em nome do destinatário do serviço. Assim, o produto do serviço é tido como algo intangível e naturalmente instável. Ademais, Gadrey, Gallouj e Weinstein (1995) destacam que os serviços são interativos, requerendo, muitas vezes, a participação conjunta do prestador e do consumidor e podendo variar em cada execução, considerando a mudança do consumidor e do prestador. Essas especificidades indicam que "o fenômeno da inovação requer uma abordagem específica, distinta daquela utilizada para a inovação na produção em geral” (JUNIOR; GUIMARÃES, 2012, p. 296).

No entanto, apenas da segunda metade da década de 1990 que apareceram os principais trabalhos, os quais discutiram em profundidade o setor de serviços e inovação, com novas teorias desenvolvidas por Gadrey et al. (1995) e Gallouj e Weinstein (1997), bem como aqueles trabalhos de análises empíricas desenvolvidos por Sundbo (1997).

É preciso mencionar que a inovação na perspectiva de serviços ocorre em função da necessidade de resposta ao caráter tecnicista conhecido pela abordagem adotada por Barras (1986). Este autor procurou enfatizar o relevante papel que as tecnologias, em especial as de informação, executam sobre o desenvolvimento econômico em sociedades capitalistas do século XX. No entendimento de Gallouj (2002), o enfoque de Barras (1986) a respeito de inovação de serviços deve ser entendido como uma visão tecnicista que contempla a importância das tecnologias de informação e comunicação (TIC) no crescimento de firmas, sem abarcar, no entanto, as especificidades da inovação de serviços. 
A inovação de serviços, sob esta perspectiva, decorre das características intrínsecas presentes na produção de um serviço. Isso porque, conforme Hauknes (1996), o enfoque em serviços ressalta a força com que as especificidades da relação de coprodução e imaterialidade dos serviços produzem a inovação e superam os aspectos tecnológicos envolvidos. Além disso, Gallouj (2002) sublinha que o setor de serviços é caracterizado por sua efemeridade ou volatilidade, e também por uma forte relação entre produtores e usuários tendo um caráter relevante para a customização.

Nesse panorama, as abordagens teóricas a respeito de inovação em serviços tentam trazer respostas para os seguintes questionamentos: As instituições pertencentes ao setor de serviços efetivamente inovam? Quais são as particularidades do processo de inovação de serviços? É preciso uma análise específica para o processo de inovação no setor de serviços? Gallouj (1998) traz respostas a essas questões ao descrever as principais abordagens referentes à inovação de serviços.

$\mathrm{O}$ autor explica que existem três abordagens teóricas principais: abordagem baseada em serviços, abordagem integradora e abordagem tecnicista. A baseada em ou orientada para serviços ressalta as particularidades de inovação de serviços e destaca inovações particulares, em especial uma grande frequência de inovações ad hoc. Já as inovações ad hoc podem ser entendidas como construções interativas entre organização e cliente de uma solução para um problema particular, portanto, com menor chance de replicação (SUNDBO; GALLOUJ, 1998). O autor ensina, também, que essa abordagem com base nos serviços é caracterizada por uma distinção entre serviços essenciais e serviços periféricos (GALLOUJ, 1998).

Ainda de acordo com Gallouj (1998), a abordagem integradora é aquela que agrega inovação de bens e serviços em uma única teoria de inovação. Assim, a referida abordagem é válida tanto para serviços, quanto para bens. O autor menciona ainda que a abordagem baseada em tecnologia, ou tecnicista, pode ser compreendida como a introdução de equipamentos ou sistemas técnicos na organização. Gallouj e Weinstein (1997), num trabalho anterior, já haviam apresentado essa forma de inovação de serviços, explicitando que a inovação deve ser vista sob uma ótica integradora.

Esses autores explicam que, além dessa visão envolver inovação em bens e de serviços, ela utiliza tanto inovação tecnológica por si só, quanto formas não tecnológicas de inovação. Portanto, de acordo com Sundbo e Gallouj (1998), inovação é a mudança de um negócio através da adição de um novo elemento ou a nova combinação de antigos elementos, devendo ser um fenômeno que possa ser reproduzido. Além disso, a inovação de serviço não 
pode ser vista apenas quando há uma inovação tecnológica, mas quando existe a criação de um novo conhecimento ou informação.

Amaral (2013) destaca que a abordagem integradora aparece como a mais adequada, uma vez que abarca as diversas características de produtos e a natureza interacional da coprodução de serviços, fazendo com que a inovação possua uma noção mais alinhada com as ideias schumpeterianas. Ademais, o setor de serviços é caracterizado por sua fluidez e claras interações entre provedores e usuários de serviços, o que motiva um tipo de inovação baseada na noção de "construção interativa" de Vargas (2006). Diante desse contexto, essa abordagem caracteriza nitidamente as especificidades tangíveis e intangíveis da inovação de serviços, sem ressaltar a separação entre os serviços e a indústria.

Normalmente, as inovações de serviços decorrem de ajustes em processos e estão mais relacionadas com inovações incrementais do que radicais. Desse modo, o tempo de desenvolvimento, em geral, é menor. Klement (2007) ressalta que é praticamente impossível realizar uma mudança no produto sem realizar mudanças no processo, já que há simultaneidade entre produção e consumo do serviço. Assim, inovação de serviços geralmente implica mudanças nos elementos do processo produtivo e do produto, simultaneamente. (SUNDBO; GALLOUJ; 1998)

A teoria da inovação desenvolveu-se tendo como alicerce a análise da inovação tecnológica em atividades manufatureiras. Em função disso, as especificidades das atividades de serviços dificultam a mensuração por meio de métodos tradicionais da economia (produtividade) e a verificação de melhorias ou mudanças em termos qualitativos (GALLOUJ; WEINSTEIN, 1997). Sundbo e Gallouj (1998) destacam que é difícil estabelecer indicadores de inovação de serviços, e que a maioria deles está relacionada à Pesquisa e Desenvolvimento em organizações produtoras de bens e, de serviços, raramente essa atividade é formalizada.

Portanto, na visão integradora a dicotomia inovações radicais/não-radicais é rompida e são apresentam outras formas de melhoria dos produtos. Gallouj e Weinstein (1997) sugerem a seguinte classificação: Inovação radical: criação de um produto completamente novo; Inovação por melhoria: melhoria de algumas características sem modificação na estrutura do sistema; Inovação incremental: a estrutura geral do sistema permanece a mesma, mas o sistema é modificado marginalmente através da adição de novos elementos, ou da substituição de elementos; Inovação ad hoc: construção interativa de uma solução para um problema particular de um cliente; Inovação recombinação: também chamada inovação arquitetural, é a 
inovação através de uma nova combinação das características finais ou técnicas, derivada de um "estoque" do conhecimento da organização. Nesse contexto, Gallouj (2007) propõe uma abordagem integradora que possa reportar a inovação tecnológica e não tecnológica, tanto nos serviços como nos bens.

Quadro 1 - Tipos de Inovação na visão Integradora

\begin{tabular}{|cc|}
\hline $\begin{array}{c}\text { Tipos de } \\
\text { Inovação }\end{array}$ & Definições na Abordagem Integradora \\
\hline Radical & $\begin{array}{c}\text { Criação de um novo conjunto de características ou de um novo conjunto (técnico, de serviço, de } \\
\text { competências etc.). Criação de produtos totalmente novos, com características absolutamente } \\
\text { distintas dos produtos anteriores e que requeiram competências totalmente diferentes, tanto do } \\
\text { produtor quanto do cliente. }\end{array}$ \\
\hline Melhoria & $\begin{array}{c}\text { Alterações de características do produto, para melhor, supostamente, sem alterar o sistema } \\
\text { como um todo. Qualidade de determinadas características por meio da aquisição de } \\
\text { competências, que se apoiam nos efeitos de aprendizado. }\end{array}$ \\
\hline Incremental & $\begin{array}{c}\text { Adição, supressão ou substituição de características técnicas ou competências, alterando um } \\
\text { sistema marginalmente. }\end{array}$ \\
\hline Recombinação & $\begin{array}{c}\text { Criação de produtos novos, com base na associação de características de dois ou mais } \\
\text { produtos. Criação de novos produtos após o fracionamento de um produto, dissociando } \\
\text { caracteristicas e combinando componentes em produtos. }\end{array}$ \\
\hline
\end{tabular}

Fonte: Gallouj (2007)

Cada tipo de inovação apresentada advém de uma análise da combinação de diferentes vetores os quais caracterizam o produto de um serviço. A figura a seguir demonstra a classificação de inovação que não se fixa na diferenciação de produto e processo e pode ser aplicada tanto aos serviços quanto à indústria.

Figura 1 - Modelo dos vetores que caracterizam os produtos do serviço

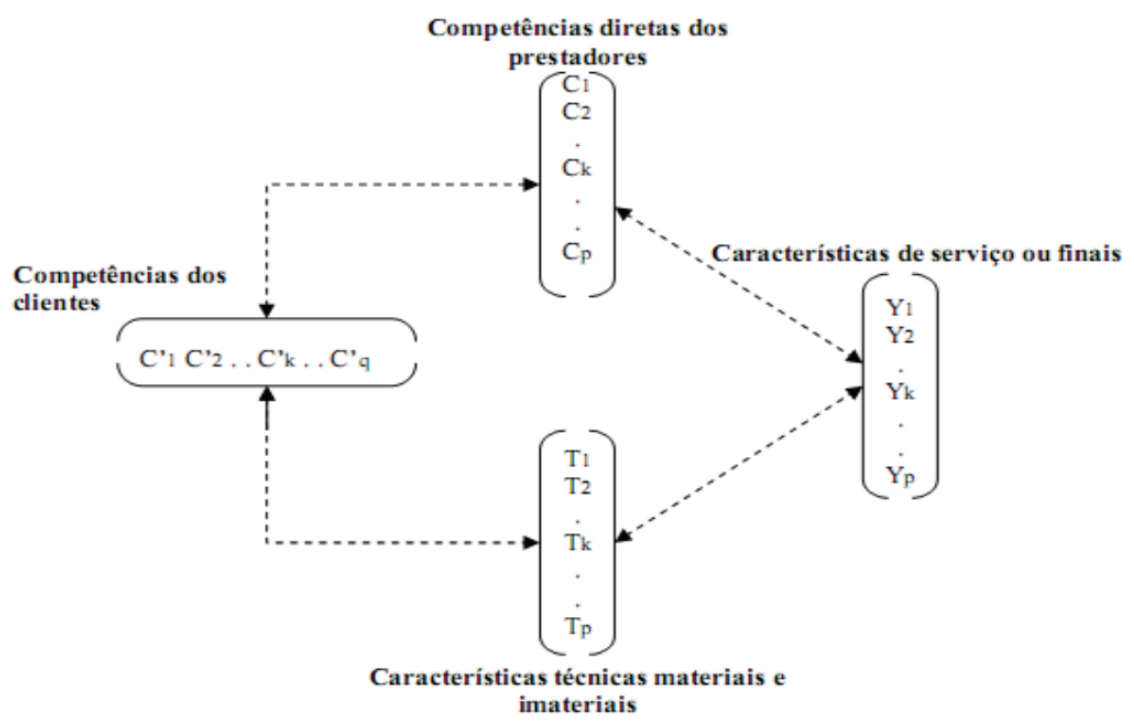

Fonte: Gallouj (2007) 
Na abordagem da inovação de serviços, os vetores (C) e (C') estão relacionados respectivamente às competências do prestador de serviço e do cliente, indicando a interface da prestação de um serviço. Já o vetor (T) corresponde às características técnicas materiais ou imateriais do processo, definindo os sistemas técnicos como métodos de produção, mobilizados para permitir a produção das características de um serviço. Por sua vez, o vetor (Y) indica as características do serviço, os valores de uso e as aplicações que o serviço possui para um determinado um cliente. As relações entre os vetores demonstradas na Figura 1 descrevem a dinâmica da prestação de um serviço, definida por Gallouj (2007, p. 14) como "a mobilização simultânea de características técnicas (materiais ou imateriais) e de competências (internas ou externas) para produzir características de serviços”.

Apropriando-se dos conceitos trabalhados, o Manual de Oslo (OCDE, 2005) registra que a inovação pode ocorrer em qualquer área da economia, incluindo serviços governamentais como saúde e educação. As diretrizes do manual, entretanto, são essencialmente voltadas para as inovações de empresas comerciais. O objetivo do Manual é oferecer diretrizes para a coleta e a interpretação de dados sobre inovação. Os dados sobre inovação podem ter muitos usos e o manual foi concebido para acomodar esses usos. Uma razão para a coleta de dados de inovação é compreender melhor essas atividades e sua relação com o crescimento econômico. Isso exige conhecimentos em atividades de inovação que têm impacto direto no desempenho da empresa (por exemplo, no aumento da demanda ou em custos reduzidos), e dos fatores que afetam sua capacidade de inovar.

Cabe destacar que o manual faz parte de uma série de publicações da instituição intergovernamental Organização para Cooperação Econômica e Desenvolvimento (OCDE), e visa orientar e padronizar conceitos, metodologias e construção de estatísticas e indicadores de pesquisa de $P \& D$ de países industrializados. Em que pese o fato de se ter como fonte padrões de países desenvolvidos, o Manual de Oslo é bastante abrangente e flexível quanto a suas definições e metodologias de inovação tecnológica e, por isso mesmo, tem sido uma das principais referências para as atividades de inovação na indústria brasileira que se quer cada vez mais competitiva. No entanto, muitos trabalhos necessitam ainda serem feitos para estudar a inovação e desenvolver um arcabouço para a coleta de dados de inovação no setor público.

Conforme OCDE (2005), uma inovação é a implementação de um produto (bem ou serviço) novo ou significativamente melhorado, ou um processo, ou um novo método de marketing, ou um novo método organizacional nas práticas de negócios, na organização do 
local de trabalho ou nas relações externas. Merece ser ressaltado o fato de que uma inovação, para ser considerada como tal, deve ter sido implementada. Um produto novo ou melhorado é implementado quando introduzido no mercado. Novos processos, métodos de marketing e métodos organizacionais são implementados quando eles são efetivamente utilizados nas operações das empresas.

O Manual define quatro tipos de inovações que encerram um amplo conjunto de mudanças nas atividades das empresas: inovações de produto, inovações de processo, inovações organizacionais e inovações de marketing. As inovações de produto envolvem mudanças significativas nas potencialidades de produtos e serviços. Incluem-se bens e serviços totalmente novos e aperfeiçoamentos importantes para produtos existentes.

Já as inovações de processo representam mudanças significativas nos métodos de produção e de distribuição. Por sua vez, as inovações organizacionais referem-se à implementação de novos métodos organizacionais, tais como mudanças em práticas de negócios, na organização do local de trabalho ou nas relações externas da empresa. Por fim, as inovações de marketing estão relacionadas com a implementação de novos métodos de marketing, incluindo mudanças no design do produto e na embalagem, na promoção do produto e sua colocação, e em métodos de estabelecimento de preços de bens e de serviços.

Ainda de acordo com o Manual de Oslo, um elemento fundamental acerca dos serviços é o fato de que a distinção entre produtos e processos é com frequência obscura. As inovações de produto podem utilizar novos conhecimentos ou tecnologias, ou podem basearse em novos usos ou combinações para conhecimento ou tecnologias existentes. O termo "produto" abrange tanto bens como serviços. As inovações de produto incluem a introdução de novos bens e serviços, e melhoramentos significativos nas características funcionais ou de uso dos bens e serviços existentes.

As inovações organizacionais em práticas de negócios compreendem a implementação de novos métodos para a organização de rotinas e procedimentos para a condução do trabalho. Mudanças nas práticas de negócios, na organização do local de trabalho ou nas relações externas baseadas em métodos organizacionais já em uso na empresa não são inovações organizacionais. Tampouco é considerada uma inovação a formulação de estratégias de gerenciamento em si. Todavia, mudanças organizacionais que são implementadas em resposta a uma nova estratégia gerencial são consideradas uma inovação se elas representarem a primeira implementação de um novo método organizacional em práticas de negócios, organização do local de trabalho ou relações externas. 
Por exemplo, uma empresa que introduz um novo produto que também requer o desenvolvimento de um novo processo é claramente uma inovadora tanto de produto como de processo. O mesmo é válido para uma empresa que introduz um novo método de marketing para comercializar um novo produto, ou uma firma que adota pela primeira vez um novo método organizacional ao introduzir uma nova tecnologia de processo (OCDE, 2005).

Diante desse contexto, faz-se necessário estabelecer a distinção entre inovações de produto e de processo. No que se refere aos bens, a diferença entre produtos e processos é clara. No entanto, para os serviços, essa distinção pode ser menos evidente pois a produção, a distribuição e o consumo de muitos serviços podem ocorrer ao mesmo tempo. Algumas diretrizes diferenciadoras são: a) se a inovação envolve características novas ou substancialmente melhoradas do serviço oferecido aos consumidores, trate-se de uma inovação de produto; b) se a inovação envolve métodos, equipamentos e/ou competências para o desempenho do serviço novos ou substancialmente melhorados, então é uma inovação de processo; c) se a inovação envolve melhorias substanciais nas características do serviço oferecido e nos métodos, equipamentos e/ou habilidades usados para seu desempenho, ela é uma inovação tanto de produto como de processo.

Igualmente, é preciso definir uma distinção entre inovações de processo e inovações organizacionais (OCDE, 2005). A diferença entre as inovações de processo e as inovações organizacionais é talvez o caso de fronteira mais frequente em pesquisas sobre inovação pois ambos os tipos de inovação procuram - entre outras coisas - reduzir custos por meio de conceitos novos e mais eficientes de produção, distribuição e organização interna.

Ademais, muitas inovações contêm aspectos dos dois tipos, como, por exemplo, a introdução de novos processos que também pode abarcar o primeiro uso de novos métodos organizacionais. As inovações organizacionais, como a introdução de um sistema gerencial de qualidade total, podem envolver melhorias significativas nos métodos de produção para evitar certos tipos de falhas, como novos sistemas logísticos de produção, ou sistemas de informação mais eficientes baseados em novos softwares e novos equipamentos de TIC.

O ponto de partida para diferenciar inovações de processo e/ou organizacionais é o tipo de atividade: inovações de processo lidam sobretudo com a implementação de novos equipamentos, softwares, técnicas ou procedimentos, enquanto as inovações organizacionais lidam primordialmente com pessoas e a organização do trabalho. Para o Manual de Oslo, as diretrizes para distinguir os dois tipos em casos de fronteira são as seguintes: a) se a inovação envolve métodos de produção ou de abastecimento novos ou significativamente melhorados 
que visam reduzir custos unitários ou aumentar a qualidade do produto, trata-se de uma inovação de processo; b) se a inovação compreende o primeiro uso de novos métodos organizacionais nas práticas de negócios, na organização do local de trabalho ou nas relações externas da empresa, ela é uma inovação organizacional; c) se a inovação implica métodos de produção ou de abastecimento novos ou significativamente melhorados, tem-se uma inovação de processo e organizacional.

Como já foi mencionado, o requisito mínimo para se considerar uma inovação é que a mudança introduzida tenha sido nova para a empresa. Um método de produção, processamento e marketing ou um método organizacional pode já ter sido implementado por outras empresas, mas se ele é novo para a empresa (ou se é o caso de produtos e processos significativamente melhorados), então trata-se de uma inovação para essa empresa. Outro tipo de inovação comumente estudado é a inovação de processo, a qual pode ser entendida como a introdução de novos processos de produção de produtos ou serviços, tais como os gerados por novas tecnologias ou novas rotinas de trabalho (SUNDBO, 2003; CARAYANNIS; GONZALEZ; WETTER, 2003).

A literatura também faz menção à inovação em gestão, administrativa ou organizacional. Apesar de poder existir sutis diferenças semânticas entre os conceitos, este trabalho utilizará tais termos como sinônimos. Birkinshaw, Hamel e Mol (2008) revisaram a literatura em inovação em gestão e a definiram operacionalmente como a geração e implementação de práticas gerenciais, processos, estrutura ou técnicas que são novas para o estado da arte e que pretendem potencializar os objetivos organizacionais. Já para Carayannis, Gonzalez e Wetter (2003), a inovação administrativa é compreendida como mudanças nas características dos elementos organizacionais e institucionais, como políticas, estrutura ou alocação de recursos, entre outros.

Como pôde ser visto nesta seção, o termo inovação tem sido objeto de vários estudos com diferentes recortes. No entanto, para o presente trabalho será adotada a definição de Gallouj (1997) acerca de inovação, qual seja: a implementação de uma mudança significativa na forma como a organização opera ou nos produtos que fornece com impacto positivo no desempenho organizacional.

A seguir, serão abordadas a inovação no contexto do setor público e as principais pesquisas desenvolvidas nessa temática, bem como as classificações mais comuns utilizadas para se identificar uma inovação na administração pública. 


\subsection{INOVAÇÃO NO SETOR PÚBLICO}

Conforme a União Europeia (2013), uma das primeiras pesquisas relevantes acerca da inovação deu-se a partir de uma perspectiva empresarial adaptada aos órgãos da administração pública, estudo que foi publicado em 1960. Porém, foi apenas em 1977 com a pesquisa de Roessner "Incentivos à inovação em organizações públicas e privadas", que se examinou diretamente a inovação no setor público. Até o início dos anos 2000, a maioria das pesquisas sobre inovação no setor público foi realizada por acadêmicos nas áreas de gestão e empreendedorismo e parece ter sido dominada por estudos de caso com foco na comparação entre as características organizacionais do setor público e privado.

Salazar e Holbrook (2004), ao estudarem as pesquisas sobre inovação, afirmam que tanto o setor privado quanto o setor público fazem inovação, mas essas pesquisas desconsideram o setor público. O setor público precisa ser objeto das pesquisas sobre inovação, especialmente aquelas focadas em serviços, já que o poder público é essencialmente um fornecedor de serviços. Os processos inovadores no setor de serviços podem melhorar a sua qualidade e alavancar sua produtividade, o que se constitui em benefício social. Assim, o serviço público precisa inovar para melhorar sua eficiência, bem como para aumentar a satisfação do usuário do serviço (SALAZAR; HOLBROOK, 2004).

Nessa linha, Mulgan e Albury (2003) enfatizam que inovação deve ser uma atividade central do setor público, pois contribui para melhorar o desempenho dos serviços públicos e para aumentar a eficiência do serviço e minimizar os custos. Além disso, o governo e os serviços públicos dependem de inovação bem-sucedida para desenvolver melhores formas de satisfazer necessidades, resolver problemas, e utilizar recursos e tecnologias. Todavia, a inovação às vezes pode ser vista como um luxo opcional ou um fardo, embora devesse ser entendida como uma atividade central que pode aumentar a capacidade de resposta dos serviços às necessidades locais e individuais.

Brandão e Faria (2013) identificaram três tipos de inovação de processo no setor público: tecnológicas, organizacionais ou administrativas e orientadas ao mercado. Inovações tecnológicas podem ser definidas como novos elementos no sistema de produção de uma organização, incluindo novas tecnologias ou novos sistemas de gestão da informação (WALKER, 2006, 2007; DAMANPOUR; WALKER; AVELLANEDA, 2009). Inovações organizacionais ou administrativas são novas abordagens e práticas que modificam as relações entre membros da organização e afetam regras, papéis, procedimentos, estruturas, comunicações e relações de troca com o ambiente externo (WALKER, 2006, 2007; 
DAMANPOUR; WALKER; AVELLANEDA, 2009). A inovação de processo orientada ao mercado envolve a modificação de procedimentos e sistemas operacionais da organização para aumentar a eficiência ou a efetividade da produção e a oferta de serviços aos usuários (WALKER, 2007).

Inovações administrativas ou organizacionais foram destacadas como um tipo independente de inovações de processos por Birkinshaw, Hamel e Mol (2008) e Carayannis, Gonzalez e Wetter (2003). Já Walker (2006, 2007) e Damanpour, Walker e Avellaneda (2009), que estudam a inovação no setor público, entendem esse tipo de inovação como um subconjunto de inovação de processo

Ferrarezi e Amorim (2007, p.17), para fins de classificação de iniciativas para o Concurso Inovação na Gestão Pública Federal da Escola Nacional de Administração Pública (Enap), consideram que "inovações são mudanças em práticas anteriores, por meio da incorporação de novos elementos da gestão pública ou de nova combinação dos mecanismos existentes, que produzam resultados significativos para o serviço público e para a sociedade”.

Vigoda-Gadot e colaboradores (2008) mencionam que a eficiência do setor público de um país e uma prestação de serviços públicos de boa qualidade são fundamentais para alcançar operações mais transparentes, podendo resultar em maior satisfação dos usuários com os serviços oferecidos e em maior nível de confiança no setor público.

As definições de inovação mais recentes contemplam uma visão mais abrangente, incluindo inovações sociais, inovações em serviços e inovações no setor público (HALVORSEN et al., 2005), sendo esta última o tema deste trabalho. Koch e Hauknes (2005), ao reconhecer o contexto da natureza do resultado da inovação, descrevem que a inovação no setor público pode ser entendida como a implementação ou desempenho de uma nova forma específica ou repertório de ação social, implementada deliberadamente por uma entidade no contexto dos objetivos e funcionalidades de suas atividades. Tais autores afirmam que ainda há amplo campo para pesquisa sobre inovação no serviço público, principalmente sobre seus resultados, em razão da pouca atenção que vem sendo dispensada a esse ramo da atividade econômica e social.

Ao longo das últimas quatro décadas, uma quantidade substancial de pesquisas empíricas sobre a inovação foi desenvolvida no setor privado. Mas ainda há uma escassez de pesquisas de alta qualidade sobre a inovação no setor público. A questão chave é como transferir esse know-how para o setor público (MULGAN; ALBURY, 2003).

Junior e Guimarães (2012), ao mapearem o campo "inovação de serviços", 
constataram igualmente o mesmo cenário. No estudo sobre o estado da arte, os pesquisadores verificaram que apenas 5\%, dos 73 artigos publicados com o tema inovação, estavam associados ao contexto da administração pública.

Já Lima e Vargas (2012) buscaram situar a discussão em revistas internacionais sobre inovação no setor público, em confronto com a teoria da inovação de serviços, visando identificar oportunidades de pesquisa. $\mathrm{Na}$ análise realizada em sete artigos internacionais, os autores concluíram que há um predomínio de publicações referentes à inovação processual ou de melhoria, e que a inovação ainda não é vista como um processo interativo e intrínseco à atividade pública.

Por sua vez, Brandão e Faria (2013), ao revisarem a literatura quanto à análise da produção científica em periódicos nacionais e internacionais da área de administração, também identificaram quadro semelhante em 30 artigos avaliados. A pesquisa das autoras visou apresentar um panorama da produção científica em periódicos nacionais e internacionais sobre inovação no setor público no período entre 2000 e 2010. Elas chegaram à conclusão que, no Brasil, a produção em tais periódicos encontra-se em estágio inicial, em contrapartida, é possível notar um número crescente de publicações nos últimos anos. Já no contexto internacional, Brandão e Faria (2013) destacam que a produção científica está mais consolidada, com três principais focos de estudo: fatores ambientais, organizacionais e gerenciais que influenciam a inovação no setor público. Foram identificadas lacunas de pesquisa em cinco temas: (a) processo de inovação, (b) indutores e barreiras, (c) características das lideranças que facilitam a inovação, (d) efeitos da inovação e (e) fatores que contribuem para a disseminação de inovações no setor público.

Isidro-Filho et al (2014) trazem relevantes contribuições na análise sobre inovação realizada tendo como pano de fundo o Concurso de Inovação na Administração Pública Federal. Eles concluem que existem menos contribuições teóricas do que empírica sobre inovação de serviços, tendo em vista que em 17 anos de existência do Concurso já são mais de trezentas iniciativas de inovação na administração pública premiadas. Esse resultado evidencia o gap entre pesquisa e a prática de inovações de serviços. Destaca-se ainda a dispersão dos referenciais teóricos na produção nacional em inovação de serviços, os quais se vinculam a diferentes abordagens que enfraquecem a análise e prejudica a consolidação de um corpo teórico que reflita adequadamente a realidade empírica.

O estudo mais recente, realizado por Moreira et al (2014), tem por objetivo realizar um levantamento bibliométrico para mapear o campo da inovação de serviços nos últimos 30 
anos. Tais autores constataram que, dos 209 artigos avaliados relativos à inovação de serviços, o tema "inovação no setor público" teve apenas $4 \%$ do total das ocorrências entre as áreas analisadas.

Conforme exposto, a inovação no setor público ainda é uma área em consolidação que vem ganhando atenção dos pesquisadores. No entanto, quando se busca por artigos que abordem: inovação e avaliação de políticas públicas; inovação e controle externo; inovação e auditoria governamental; inovação e Entidades de Fiscalização Superior; inovação e TCU, não são encontradas publicações que abranjam esses termos em conjunto, o que demonstra a necessidade de realização de pesquisa nessas áreas.

\section{Instrumentos de medida de inovação no setor público}

Uma das iniciativas realizadas no sentido de preencher essa lacuna ocorreu na Europa com a criação do Innobarometer em 2001. Trata-se de um instrumento utilizado pela União Européia que, por meio de pesquisas anuais, busca identificar atitudes e atividades relacionadas com a política de inovação. Desde sua criação até o ano de 2014, o Innobarometer já foi aplicado 12 vezes com diferentes enfoques.

Para esse instrumento, inovação é um termo usado de forma muito ampla, geralmente referindo-se a novas formas de alcançar um objetivo. A ênfase está na aplicação, ou seja, qualquer melhoria significativa nas práticas operacionais (ou na faixa de produto/serviço ou em estruturas de apoio) pode ser classificada como uma inovação (UNIÃO EUROPÉIA, 2010).

O Innobarometer é conduzido como parte do Eurobarometer. Ele fornece ao setor privado e ao público em geral informações relevantes sobre política de inovação que não estão disponíveis a partir de outras fontes. O Eurobarometer faz parte de uma série de pesquisas de opinião pública realizada regularmente em nome da Comissão Europeia desde 1973. Essas pesquisas abordam uma grande variedade de temas da atualidade relacionados com a União Europeia (EU) em todos os Estados-Membros da UE.

Merece destaque a elaboração em 2010 do Innobarometer que tinha como foco a inovação na administração pública, tendo sido aplicado em 27 países da União Européia e também na Noruega e na Suíça. Seu objetivo era estudar as estratégias de inovação do Setor Público Europeu em resposta às mudanças referentes a restrições e oportunidades.

As principais conclusões Innobarometer 2010 demonstram que o setor público é altamente inovador, com dois entre três órgãos da administração pública tendo introduzido 
pelo menos uma inovação de serviços. A maioria dos impulsionadores (drivers) são de ordem "estrutural", com destaque para a introdução de novas leis e regulamentos. Barreiras à inovação são, provavelmente, tão importantes quanto os impulsionadores. De acordo, com os resultados do Innobarometer 2010, a falta de recursos humanos ou financeiros e a ausência de apoio da alta administração e de incentivos para os funcionários são as barreiras mais importantes para a inovação no setor público. Por outro lado, ideias de funcionários, de gerentes e de clientes são as principais fontes de informação utilizadas no desenvolvimento de inovações. A inovação na administração pública tem efeitos positivos sobre a melhoria do acesso do usuário à informação, melhoria da satisfação do usuário e a entrega mais rápida de serviços (UNIÃO EUROPÉIA, 2010).

Outra iniciativa de se analisar a inovação ocorreu em 2011 quando foi desenvolvido o projeto de pesquisa "Medindo a inovação no setor público nos países nórdicos" (MEPIN, 2011). O objetivo do referido projeto é desenvolver uma estrutura de medição para coletar dados internacionalmente comparáveis sobre a inovação no setor público, que irão contribuir para compreensão do que é inovação no setor público e como organizações públicas inovam, e também desenvolver métricas para uso na promoção da inovação do setor público (MEPIN, 2011).

Esse projeto ficou conhecido como Manual de Copenhagen e sua estrutura conceitual inclui medidas de inovações, insumos para o processo de inovação, e uma série de indicadores que procuram medir como as organizações do setor público inovam. Além disso, medidas de impacto também são examinadas, embora sejam mais difíceis de aferir.

O conceito de inovação escolhido pelo Manual é operacionalizado tanto por meio de uma definição geral de inovação quanto por uma distinção de quatro tipos individuais de inovação: produto, processo, organização e comunicação. As definições procuram levar em consideração a natureza dos serviços públicos, que muitas vezes são técnicos e menos orientados para as pessoas, e ao mesmo tempo busca-se manter a comparabilidade com as definições utilizadas pelo Manual de Oslo para o setor privado.

Mais recentemente, em 2013, a União Européia criou o Painel de Inovação do Setor Público (European Public Sector Innovation Scoreboard - EPSIS). Essa iniciativa visa capturar e presentar a inovação neste setor de um modo a incentivar e facilitar a atividade de inovação em todo a administração pública. O EPSIS 2013 é uma das tentativas no âmbito da União Européia para melhor compreender e analisar a inovação no setor público.

Por fim, o EPSIS adverte que a inovação é um fenômeno pouco pesquisado e, talvez 
ainda mais, pouco documentado. Entretanto, reconhece que tem havido várias iniciativas notáveis recentes na Europa e em outros países que procuraram avançar na compreensão dessa temática e também em teste de ferramentas de coleta de dados, como, por exemplo, o projeto MEPIN na Escandinávia (UNIÃO EUROPÉIA, 2013).

Tanto o Painel de Inovação do Setor Público - EPSIS (UNIÃO EUROPÉIA, 2013) quanto o Innobarometer (UNIÃO EUROPÉIA, 2010) utilizam a mesma definição para inovação, qual seja: uma inovação é um serviço novo ou significativamente melhorado, método de comunicação, processo ou método organizacional.

Já o Manual de Copenhagen (MEPIN, 2011) define inovação como a implementação de uma mudança significativa na forma como a organização opera ou nos produtos que fornece. Inovações implicam alterações novas ou significativas para serviços e bens, processos operacionais, métodos organizacionais, ou a forma como a organização se comunica com os usuários. Ademais, inovações devem ser novas para a sua organização, embora possam ter sido desenvolvidas por outros. Elas podem ser o resultado de decisões decorrentes da própria organização ou em resposta a novas regulamentações ou medidas políticas.

Em relação aos tipos de inovação no setor público, o Manual de Copenhagen (MEPIN, 2011) e o EPSIS (UNIÃO EUROPÉIA, 2013) estabelecem quatros alternativas: a) Inovação de produto: é a introdução de um serviço ou bem que é novo ou significativamente melhorado em comparação com os serviços existentes ou bens da organização. Isso inclui melhorias significativas no serviço ou nas características do bem, no acesso ao cliente ou na forma como ela é usada; b) Inovação de processo: é a implementação de um método para a produção e fornecimento de bens e serviços que é novo ou significativamente melhorado em comparação com os processos existentes na organização. Isso pode envolver melhorias significativas nos equipamentos e/ou habilidades; c) Inovação organizacional: é a implementação de um novo método para a organização ou gestão do trabalho que difere significativamente dos métodos existentes na organização. Isso inclui melhorias significativas ou novos sistemas de gestão ou nova forma de organização no local de trabalho; e d) Inovação em comunicação: é a implementação de um novo método de promoção da organização ou dos seus serviços e produtos, ou novos métodos para influenciar o comportamento dos indivíduos ou outros. Estes devem se diferenciar significativamente de métodos de comunicação já existentes em sua organização.

Ao comparar os conceitos trazidos pelo Manual de Copenhagen e pelo EPSIS, é 
possível perceber que esses documentos se basearam em Sundbo e Gallouj (1998), teóricos da inovação de serviços. Pode-se notar que as definições para inovação de processo e inovação organizacional permanecem basicamente as mesmas para o setor privado e para o setor público. Contudo, a inovação de produto é substituída pela inovação de serviços e a de marketing é trocada por inovação em comunicação.

Ainda analisando as definições apresentadas anteriormente, é possível identificar que, tanto no setor público quanto no privado, o requisito mínimo para se definir uma inovação é que ela seja inédita ou significativamente melhorada para a organização. Isto inclui produtos, processos e métodos que as organizações desenvolvem de maneira pioneira e/ou aqueles que foram adotados de outras empresas ou organizações. Outro aspecto importante que merece destaque é que a ideia, prática ou processo deve ter sido implementado para que possa ser considerado uma inovação (BRANDÃO; FARIA, 2013).

Em resumo, inovação no setor público pode ser entendida como "implementação de uma mudança significante no modo como uma organização opera e provê produtos" e compreende "novas ou significantes mudanças nos serviços e bens, processos operacionais, métodos organizacionais, ou no modo como a organização se comunica com os consumidores" (BLOCH, 2010, p. 27).

Do exposto até o momento, verifica-se a polissemia existente, em maior ou menor grau, do conceito relativo à inovação. Entretanto, as definições apresentadas acabam ancoradas em pontos comuns que podem ser resumidos da seguinte forma: a inovação é uma prática que, após ter sido implementada, produz um impacto positivo no desempenho organizacional.

Entretanto, essa relação (inovação e desempenho) ainda é pouco explorada, conforme afirmam Walker, Damanpour e Devece (2010) que estudaram gestão do desempenho, desempenho organizacional e inovação em gestão, e propuseram o modelo a seguir. 
Figura 2: Modelo conceitual de Walker, Damanpour e Devece (2010)

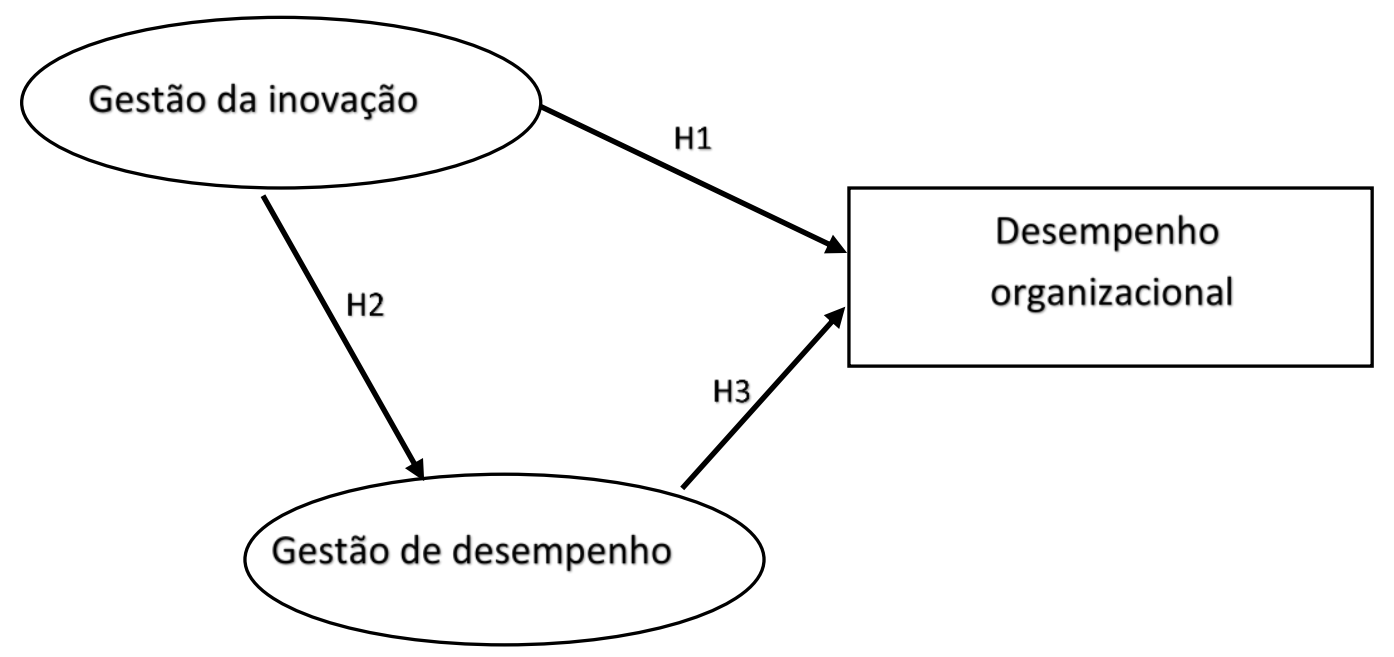

Fonte: Walker; Damanpour e Devece (2010).

Os referidos pesquisadores analisaram o papel mediador da gestão do desempenho no desempenho organizacional e descobriram que: (i) inovação em gestão não tem impacto direto no desempenho organizacional; (ii) a gestão do desempenho afeta diretamente o desempenho organizacional; e (iii) o efeito da inovação em gestão no desempenho organizacional é mediado pela gestão do desempenho. Os autores destacam, portanto, que, para obter os melhores resultados pela introdução de inovações em gestão, faz-se necessário assegurar que estruturas apropriadas de gestão do desempenho estejam efetivamente implementadas, sob risco de não impactar positivamente o desempenho organizacional.

Ao extrapolar para outros contextos, a relação inovação e desempenho se reveste de uma maior complexidade ao ser analisada no âmbito do setor público já que os parâmetros objetivos, utilizados na esfera privada como lucratividade e faturamento, não se amoldam à realidade da administração pública, ainda mais quando se trata da área de serviços públicos.

Segundo o Manual de Oslo (2005) a relação inovação e desempenho para empresas é mais fácil de ser observável e mensurável, sendo essa relação mais sutil no setor público.

É fundamental entender por que as empresas inovam. A razão última é a melhoria de seu desempenho, por exemplo pelo aumento da demanda ou a redução dos custos. A inovação visa melhorar o desempenho de uma empresa com o ganho de uma vantagem competitiva (ou simplesmente a manutenção da competitividade) por meio da mudança da curva de demanda de seus produtos (por exemplo, aumentando a qualidade dos produtos, oferecendo novos produtos ou conquistando novos mercados ou grupos de consumidores), ou de sua curva de custos (por exemplo, reduzindo custos unitários de produção, compras, distribuição ou transação), ou pelo aprimoramento da capacidade de inovação da empresa (por exemplo aumentando sua capacidade para desenvolver novos produtos ou processos ou para ganhar e criar novos conhecimentos) (Manual de Oslo, 2005, p. 36).

Portanto, as firmas inovam para garantir a atual posição competitiva e buscar novas 
vantagens em seu nicho de mercado. Além disso, a capacidade de proteger inovações tem uma importante influência na atividade inovadora e contribui para a manutenção de vantagem competitiva.

Nesse contexto, Castro-Lucas (2011, p. 139) explica que inovação está vinculada à variável conhecimento, "uma vez que determinadas possibilidades poderão surgir, respondendo às necessidades articuladas ou latentes, que reduzam custos e aumentem a produtividade".

Já na administração pública, a inovação assume nova roupagem. Se no setor privado a lógica dos incentivos, na maioria dos casos, se dá em função do lucro, "no setor público os incentivos são menos claros e, com certeza, bastante tênues, o que torna a discussão inovação no setor público - bastante árdua" (OLIVEIRA, 2014, p. 6)

Em que pese a inovação ser tão ou mais importante que no setor privado, na administração pública há um estimulo para que as práticas inovadoras sejam publicizadas e expandidas para outros contextos, sem a necessidade de instituir mecanismos que garantam a proteção e o sigilo da inovação. Com efeito, no setor público, a replicação de ações inovadoras visa atingir o maior número de interessados tendo como pano de fundo a busca por serviços públicos de qualidade que atendam ao interesse público.

Cabe relembrar que a atividade central do setor público está relacionada com a prestação de serviços. No caso do TCU, as atribuições do órgão de controle são exercidas por meio de atividades, as quais possuem características que permitem classificá-las como serviços, o que requer a análise da inovação sob o enfoque dos serviços e sua relação com o desempenho organizacional.

Por último, é preciso reiterar que no presente trabalho será adotado o conceito de inovação de serviços descrito por Gallouj (1997), o qual foi incorporado e adotado pelo Manual de Copenhagen (MEPIN, 2011), e pelo EPSIS (UNIÃO EUROPÉIA, 2013) podendo

ser definido como: a implementação de uma mudança significativa na forma como a organização opera ou nos produtos que fornece com impacto positivo no desempenho organizacional.

\subsection{DESEMPENHO NO SETOR PÚBLICO}

O desempenho é tema de interesse de todos os países em função do impacto no desenvolvimento econômico e no bem-estar social (DANTAS; QUEIROZ; QUEIROZ, 2010). Por isso, a partir de 1980, o desempenho passa a ter um papel ainda mais importante nos 
serviços públicos, com destaque nos projetos de reformas administrativas levadas a cabo por governos de diferentes países, em especial, no âmbito da Nova Gestão Pública.

Warin (1997) menciona que, com essa nova filosofia, pretendia-se reduzir os custos administrativos vis-à-vis ao aumento da produtividade das instituições públicas, com vistas a aperfeiçoar o serviço que se presta ao seu destinatário final, o cidadão. No plano nacional, Dantas, Queiroz e Queiroz (2010, p. 2) destacam que, “de uma forma genérica, pode-se dizer que o setor público, no Brasil, vem há algum tempo experimentando um processo contínuo de reformatação e redefinição de seu ambiente e de suas práticas”.

Nesse panorama, para aperfeiçoar seu desempenho, os governos têm enfrentado diariamente desafios e barreiras a fim de garantir o maior benefício possível em função da arrecadação e aplicação dos recursos públicos. Outro desafio relativo à melhoria do desempenho administrativo consiste no aumento da transparência dos atos administrativos, bem como no incremento da capacidade de prestar contas à sociedade e no maior uso de práticas de gestão mais eficientes (GUZMÁN, 1991). Assim, o poder público, além de ser econômico, eficiente e eficaz, deve ser capaz de demonstrá-lo.

$\mathrm{Na}$ abordagem da questão do desempenho no setor público, é preciso antes trazer à tona os objetivos envolvidos nessa temática. Grateron (1999) relembra que, no cenário complexo da administração pública, os objetivos do setor público são múltiplos e envolvem diversos atores e interesses, em contrapartida ao que acontece no setor privado cuja principal finalidade é a obtenção de benefícios ou lucro. Os governos proveem serviços públicos e distribuem riquezas em razão de aspectos sociais, culturais e econômicos. Assim, o benefício (ou lucro) que o governo busca está insculpido no bem comum da sociedade por ele representada.

O constructo desempenho, nesta dissertação, é discutido sob o enfoque organizacional sem se restringir ao desempenho de indivíduos ou de equipes. Desse modo, desempenho da organização será entendido e explicado por meio de resultados que refletem o atendimento às necessidades das partes interessadas da instituição: usuários dos serviços, servidores, fornecedores, sociedade e governo.

Em decorrência da crescente relevância do desempenho organizacional na esfera pública, emerge, então, a necessidade de se instituir mecanismos capazes de avaliar objetivamente o desempenho público, assim como ocorre na administração de empresas privadas.

Gomes e Guimarães (2013) afirmam que a avaliação de desempenho de empresas 
privadas é um procedimento institucionalizado, que tem se mostrado importante para a sobrevivência organizacional. Já no setor público ainda existem desafios a serem superados a respeito do tema. No caso dos bens e serviços produzidos pelo setor público, os produtos ou resultados finais nem sempre são facilmente perceptíveis e, muitas vezes, são de difícil mensuração.

Ocorre que a avaliação do desempenho na esfera pública tem se limitado ao desempenho de seu corpo de servidores, em detrimento de uma avaliação de desempenho que contemple tanto o plano individual quanto institucional. Coelho Jr. (2009) sublinha que as primeiras medidas de desempenho se restringiam a fornecer feedbacks aos administradores sobre a atuação dos funcionários, e focavam nas características e personalidades dos indivíduos em prejuízo dos resultados obtidos e do alcance das metas da instituição.

O Relatório da OCDE alerta que "o conceito de desempenho adquire novas dimensões quando se passa da organização para a equipe e o indivíduo" (OCDE, 2010, p. 207). Além disso, menciona que é necessária uma interligação entre objetivos estratégicos, intermediários (ou táticos) e individuais.

Neto (2013) salienta que no setor público a avaliação de desempenho originou-se nos anos iniciais do século XX, com abordagens cujo enfoque consistia na adoção de modelos lógicos e racionais, como as teorias do gerenciamento científico e da gestão administrativa. Posteriormente, segundo o referido autor, houve evolução para modelos de avaliação voltados a sistemas mais abertos e adaptáveis, que admitiam a existência de outras variáveis capazes de interferir no desempenho organizacional, como as dependentes de contexto ou ambiente.

Por sua vez, Gomes e Guimarães (2013) chamam a atenção para o fato de que um exame dos modelos de avaliação de desempenho no setor público ressalta a diversidade de perspectivas e abordagens. Assim, a mensuração de desempenho no setor público se distancia de um foco mais racional e técnico sobre os procedimentos de trabalho e a eficiência dos processos e aproxima-se de sistemas mais participativos e de múltiplos níveis, com foco explícito no resultado dos programas. Atualmente, a avaliação de desempenho tem se expandido e buscado fomentar a promoção de um governo mais eficiente e transparente, no entanto, pouco se apresenta como uma ferramenta para responsabilização dos gestores em função dos resultados por eles alcançados.

Nesse panorama, a prestação de contas (accountability) aparece como um dos principais objetivos da avaliação de desempenho do setor público, a qual tem ultrapassado a mera avaliação do desempenho financeiro e da eficiência em direção ao desenvolvimento de 
medidas que sejam, também, informativas e úteis aos gestores públicos, para orientá-los a melhorar a qualidade dos serviços públicos e de seus resultados (PETERS; PIERRE, 2010).

Dessa maneira, a qualidade dos bens e serviços públicos deve ser mensurável para que se promova uma melhoria do desempenho das atividades e projetos, o que passa pela instituição de indicadores que permitam a realização de avaliações e monitoramentos das políticas e programas de Governo.

Nesse contexto, o desempenho do setor público pode ser medido e avaliado mediante a utilização de parâmetros ou indicadores que considerem a eficácia, eficiência e efetividade da ação governamental, de modo que os resultados na esfera pública possibilitem democratizar o acesso em todos os níveis; ser permeável ao controle da sociedade; melhorar a qualidade dos serviços prestados e aumentar o grau de resolutividade dos problemas (SIQUEIRA, 1990).

Os indicadores são instrumentos que possibilitam identificar e medir aspectos relativos a um fenômeno ou resultado de uma intervenção na realidade. Um dos seus objetivos é traduzir de modo mensurável determinado aspecto da realidade, a fim de que a observação e avaliação sejam operacionais (MP/SPI, 2010). Na área de políticas públicas, os "indicadores apontam, indicam, mensuram, traduzem em termos operacionais as dimensões sociais de interesse definidas a partir de escolhas teóricas ou políticas realizadas anteriormente" (VALLE, 2011, p. 33).

Além disso, o uso de indicadores visa subsidiar as atividades de planejamento público e a formulação de políticas sociais nas diferentes esferas de governo (JANUZZI, 2005). Os indicadores de desempenho fornecem uma visão acerca dos resultados que se deseja mensurar, mas são aproximações do que realmente ocorre. Sendo assim, necessitam de uma interpretação do contexto em que estão inseridos (TCU, 2000).

Um indicador de desempenho é um número, percentagem ou razão que mede um aspecto do desempenho, com o objetivo de comparar esta medida com metas preestabelecidas (BRASIL, TCU, 2000, p. 09)

Portanto, os indicadores são métricas que proporcionam informações sobre o desempenho de uma política ou programa. São instrumentos de gestão essenciais nas atividades de monitoramento e avaliação das organizações, assim como seus projetos, programas e políticas, pois permitem acompanhar o alcance das metas, identificar avanços, melhorias de qualidade, correção de problemas, necessidades de mudança etc. Pode-se dizer que os indicadores possuem duas funções principais: a primeira é a descrição por meio da geração de informações do estado real dos acontecimentos e o seu comportamento; a segunda é de caráter valorativo que consiste em analisar as informações presentes com base nas 
anteriores de forma a realizar proposições valorativas.

Neste sentido, uma forma objetiva de se avaliar o desempenho no setor público é a utilização de indicadores de desempenho de forma a minimizar as avaliações subjetivas dos stakeholders. A utilização de indicadores visa um propósito o qual pode ser observado sob duas perspectivas diferentes. A primeira, do ponto-de-vista do administrador público ao proporcionar ferramentas que lhe permitam gerenciar melhor os recursos disponíveis, ao mesmo tempo em que possa prestar contas ou informar a comunidade sobre o uso destes recursos; a segunda, da ótica do cidadão e de órgãos de controle, que poderão exercer um melhor controle e avaliação do desempenho do gestor público (NETO, 2013).

Assim, os órgãos de controle, como o TCU, têm a obrigação legal de não apenas acompanhar a boa e regular aplicação dos recursos públicos, como também avaliar a efetividade dos programas, os resultados alcançados e os benefícios advindos. Neto (2013) ressalta que a necessidade de prestar serviços e administrar os recursos do cidadão de maneira eficiente, econômica e eficaz, além da necessidade de fornecer instrumentos aos gestores públicos para demonstrar a transparência nos atos públicos, tem possibilitado a realização de auditorias para avaliação do desempenho da administração pública com a instituição de indicadores de gestão.

\subsection{AVALIAÇÃO DE POLÍTICAS PÚBLICAS E O PAPEL DO TCU}

É cediço que a avaliação de políticas públicas é imprescindível para a melhoria da administração pública. Para Ramos e Schabbach (2012), a avaliação de políticas públicas define parâmetros fundamentais para se decidir se uma política deve continuar a ser implementada ou não, caso não esteja atingindo os resultados esperados. Além disso, a avaliação gera uma retroalimentação que permite escolher entre diferentes projetos de acordo com sua eficácia e eficiência, e, ao cotejar os resultados, possibilita retificar as ações e reorientá-las em direção ao fim postulado (COHEN; FRANCO, 2004).

Na ótica de Costa e Castanhar (2003), a avaliação sistemática, contínua e eficaz aparece como ferramenta gerencial relevante, disponibilizando aos formuladores de políticas públicas e aos gestores de programas condições para incrementar a eficiência e efetividade dos recursos aplicados em programas governamentais. Os autores destacam que historicamente na administração pública brasileira não há a preocupação de avaliar programas públicos.

$\mathrm{Na}$ América Latina, a institucionalização da "função avaliação" aconteceu apenas 
entre o final da década de 1980 e o início da década de 1990, sendo instrumentalizada para o sucesso da reforma do Estado a partir de três propósitos básicos: a) a adoção de uma perspectiva de contenção dos gastos públicos, b) a busca de melhoria da eficiência e da produtividade, de ampliação da flexibilidade gerencial e da capacidade de resposta dos governos, c) a maximização da transparência da gestão pública e de responsabilização dos gestores, o consumidor vindo em primeiro plano (MELO, 1998).

Em um plano normativo, a década de 1990 testemunhou, nas democracias ocidentais de uma maneira geral, e na América Latina particularmente, a busca de fortalecimento da “função avaliação" na gestão governamental. Com efeito, foram implementados, em diversos países da América Latina, sistemas de avaliação das políticas públicas de escopo variável (FARIA, 2005).

Na área ambiental, a avaliação também chega tardiamente, e não poderia ser diferente, já que as primeiras políticas ambientais surgiram a partir do final da década de 1960, por exemplo, no Japão em 1967 e nos Estados Unidos em 1970 (MICKWITZ, 2006). Usado inicialmente para políticas sociais, o leque de atuação da avaliação foi se expandindo para outras áreas da política, até chegar à área ambiental, somente nos anos 1990. Esse relativo atraso pode ser atribuído ao fato de a política ambiental ser relativamente recente, mas também se deve a características intrínsecas da política ambiental que tornam a avaliação bastante complexa, em função da transversalidade do tema. Por outro lado, essa incorporação tardia traz o benefício de se poder usar as experiências de outras áreas, evitando repetir os mesmos erros (ASSIS et al.,2012).

Assim, o campo se firma apenas no final da década de 1990, e segundo Lehtonen (2005) com base nas funções de a) aprendizado e desenvolvimento e b) accountability. Além disso, Mickwitz (2006) destaca também a necessidade de convencer os políticos e o público de que as políticas ambientais são necessárias e boas para a sociedade como um todo.

Mickwitz (2006) considera política ambiental como o conjunto de esforços com o qual as autoridades públicas exercem seu poder na tentativa de melhorar ou evitar a deterioração da qualidade ambiental. Já Kraft (1996) entende que política ambiental abrange uma série de ações governamentais que produz ou tenta produzir efeitos sobre a qualidade ambiental ou o uso dos recursos naturais. Isso representa uma decisão coletiva com a qual a sociedade busca determinadas metas e objetivos usando ferramentas específicas para atingi-las, frequentemente em um tempo determinado.

A política ambiental não é encontrada em uma única lei ou estatuto. Normalmente, ela 
é um agregado de leis, regulamentos, decisões dos tribunais e atitudes e comportamentos de funcionários públicos encarregados de elaborar, implementar e fazer cumpri-la. A política ambiental inclui o que o governo escolhe fazer para proteger a qualidade ambiental e os recursos naturais, bem como aquilo que ele escolhe não fazer, permitindo outras influências, como os mecanismos de decisão privados, para determinar os resultados no meio ambiente (ASSIS et al.,2012). Portanto, assim como as demais políticas públicas, a política ambiental também precisa ser objeto de avalições sistemáticas.

Nesse contexto, ganha relevo o papel do Tribunal de Contas da União (TCU) que, conforme artigo 70 e seguintes da Constituição Federal, realiza a atividade de controle externo em auxílio ao Congresso Nacional. Dentre suas atividades de controle externo, o TCU executa auditorias operacionais as quais podem ser definidas como o "exame independente e objetivo da economicidade, eficiência, eficácia e efetividade de organizações, programas e atividades governamentais, com a finalidade de promover o aperfeiçoamento da gestão pública" (TCU, 2010, p. 7).

O Manual de Auditoria Operacional do TCU (2010) dispõe que as auditorias operacionais possuem características próprias que as distinguem das auditorias tradicionais. Ao contrário das auditorias de regularidade, que adotam padrões relativamente fixos, as auditorias operacionais, devido à variedade e complexidade das questões tratadas, possuem maior flexibilidade na escolha de temas, objetos de auditoria, métodos de trabalho e forma de comunicar as conclusões de auditoria.

Desse modo, as auditorias operacionais empregam ampla seleção de métodos de avaliação e investigação de diferentes áreas do conhecimento, em especial das ciências sociais, o que permite realçar um papel mais moderno dos órgãos de controle no processo de avaliação de políticas públicas com enfoque nos resultados e não apenas nos aspectos orçamentários e financeiros.

Nesse sentido, a auditoria operacional, focada em aspectos de eficácia, eficiência e efetividade, surge no contexto de reformas administrativas como respostas governamentais aos anseios sociais voltados a melhores resultados do aparelho estatal. Atualmente, a sociedade exige que o administrador público atue, no âmbito de cada instituição, de tal forma que o cumprimento das leis e regulamentos não seja mais o objetivo maior do seu trabalho, um fim em si mesmo, mas sim, o meio pelo qual as reais demandas sociais são atendidas, de forma satisfatória e igualitária. Nessa vertente, pode-se afirmar que: controle bem mais que a aferição da conformidade com as normas de execução 
orçamentária e de regularidade das despesas. O cidadão hoje reivindica com legitimidade o acesso a elementos de informação que lhe permitam avaliar os resultados das ações dos gestores públicos e sua adequação aos compromissos assumidos com a sociedade. É a participação democrática que decorre do exercício do voto e implica a prerrogativa de se exigir a correspondente prestação de contas (TCE-SP, 2014, p. 4).

Portanto, não basta apenas cumprir aquilo que as normas impõem, exigindo-se principalmente que a atuação administrativa seja realizada com qualidade, tempestividade, economicidade, eficiência e efetividade. A atuação do gestor moderno torna-se ainda mais complexa, bem como o perfil da sociedade que ele representa.

Assim, a auditoria operacional incorpora ideias chaves da Nova Gestão Pública, tais como, eficiência, economia, efetividade, boas práticas de gestão, boa governança, qualidade de serviço e atendimento de metas (GOMES, 2002), sendo a própria Nova Gestão Pública aquela que oferece o arcabouço teórico para ampliar a competência legal das instituições de auditoria, de forma a incluir a auditoria de desempenho.

Na medida em que a auditoria de desempenho busca realizar uma avaliação da gestão pública com vistas a identificar oportunidades de melhorias, boas práticas, sugerir recomendações às instituições públicas e não possui o caráter de punição, observa-se um enfoque gerencial nos trabalhos de auditoria governamental.

Ademais, assim como prega o gerencialismo, a auditoria operacional volta-se para o aperfeiçoamento da gestão pública com ações corretivas e concomitantes que provocam impacto no presente e trarão resultados no futuro, ao contrário da auditoria de conformidade, que trabalha com responsabilização de condutas passadas. Essa forma mais moderna de atuação do TCU se reflete no papel de órgão de controle que busca induzir a modernização das organizações fiscalizadas em direção a uma administração mais eficiente.

Nessa seara cabe transcrever o trecho a seguir:

A função básica do TCU é exercer o controle externo nos três poderes, relativamente
ao uso dos recursos e bens públicos federais. Nos últimos anos, o TCU vem
trabalhando também para a melhoria do desempenho da administração pública, e
não apenas para punir administradores governamentais, assumindo, em certa
medida, o papel de induzir a modernização das organizações fiscalizadas. (FARO;
AMORIM; TREVISAN; JUNQUEIRA, 2010 p. 711-712).

Cabe esclarecer que a utilização de diferentes métodos e de diversas áreas do conhecimento nas auditorias operacionais se dá em função extensa competência atribuída ao TCU pela Constituição Federal de 1988, que assegurou à Corte de Contas Federal maior poder de atuação, inclusive na área ambiental. Para Lima (2005), o TCU vem desempenhando de forma crescente um importante papel na avaliação das políticas ambientais públicas do 
governo federal. A realização de diversas auditorias operacionais em instituições e programas governamentais têm resultado em minuciosos diagnósticos e relevantes recomendações, no sentido de tornar mais efetivas as políticas públicas ambientais (LIMA, 2005). Ressalta-se que há uma clara preocupação não apenas com os aspectos da legalidade, mas também com a eficiência dos instrumentos da política ambiental.

Embora sejam realizadas pelo TCU diversas auditorias com o tema meio ambiente, tais avaliações nem sempre conseguem analisar de forma sistêmica o objeto auditado (HEDLER; TORRES, 2009). Em decorrência do escopo reduzido e do limitado número de atores envolvidos na avaliação, as auditorias acabam produzindo diagnósticos mais focados e menos abrangentes, o que leva a obter uma visão parcial do objeto auditado, apesar de o meio ambiente requerer uma abordagem mais ampla, em função de ser um tema transfronteiriço que não se restringe aos limites geopolíticos de estados e países (LIMA, 2005).

Nesse cenário, torna-se muito complexo, por exemplo, identificar a contribuição da atuação do TCU para a melhoria da política pública, uma vez que as recomendações propostas podem ser estanques e pontuais. Além disso, a ausência de critérios objetivos dificulta medir o desempenho da política, e traz ao controle externo barreiras para um acompanhamento ao longo do tempo mais efetivo. Nessa linha, Hedler e Torres (2009) constataram a necessidade de que as auditorias do TCU estabeleçam delineamentos que possibilitem comparações cronológicas dos resultados da política avaliada e que sirvam de linha de base para a realização de estudos longitudinais.

Levando em consideração essa nova perspectiva, houve uma mudança na forma de trabalho, notadamente na abordagem utilizada na auditoria em unidades de conservação, já que foram empregadas novas ferramentas para avaliar a política ambiental, conforme poderá ser visto a seguir com o detalhamento do Indimapa.

\section{3 - INDIMAPA}

Inicialmente convém informar que o Tribunal de Contas da União não está isolado na sua preocupação em exercer o controle externo na área ambiental. A emergência desse tema como uma questão política maior no cenário internacional levou outras Entidades Fiscalizadoras Superiores (EFS) a desenvolverem instrumentos e métodos para a auditoria ambiental, segundo a legislação de seus respectivos países, destacando-se o Canadá, a Holanda, o Reino Unido e a Colômbia.

Nesse contexto se encaixa a International Organization of Supreme Audit Institutions 
(Intosai) que é uma organização guarda-chuva para a comunidade de auditoria externa e reúne cerca de 192 EFS. Tendo sido fundada em 1953, a Intosai é uma organização nãogovernamental, autônoma, independente e apolítica. Possui status consultivo especial no Conselho Econômico e Social das Nações Unidas.

A referida organização estabeleceu em 1992 um grupo permanente de trabalho em auditoria ambiental, denominado WGEA (Working Group on Environmental Auditing). Seus principais objetivos são: apoiar as entidades fiscalizadoras superiores - para uma melhor compreensão das questões relacionadas à auditoria ambiental - e promover o intercâmbio de informações e de experiências nesse campo, além de publicar diretrizes e outros materiais informativos para uso dessas entidades fiscalizadoras, incluindo sugestões de métodos para a realização das auditorias (LIMA, 2005).

A Intosai possui grupos regionais espalhados pelo mundo. Um deles é a Organização Latino-americana e do Caribe de Entidades Fiscalizadoras Superiores (Olacefs) que foi criada em 1965. Ela é composta por diversos órgãos, tendo destaque a Comissão Técnica Especial de Meio Ambiente (Comtema), cujo estabelecimento ocorreu em 1998.

O principal objetivo da Comtema é propiciar a realização de auditorias ambientais pelas EFS membros da Olacefs. No plano de trabalho da organização para o biênio 2013/2014, por exemplo, foi planejada a execução de uma auditoria coordenada em biodiversidade. As EFS decidiram estabelecer como escopo a avaliação da gestão de áreas protegidas/unidades de conservação e também o ano de 2014 para iniciar os trabalhos.

Paralelamente, em 2013, o TCU, ciente da perspectiva da realização de um trabalho internacional nessa área, optou por realizar, como piloto, uma auditoria coordenada em conjunto com nove Tribunais de Contas Estaduais (TCEs) na gestão das unidades de conservação do bioma Amazônia. Foi no âmbito desse projeto que se criou um método de avaliação da implementação e da gestão dessas áreas, objeto da presente pesquisa.

Assim, o Plenário do Tribunal de Contas da União deliberou no sentido que fosse realizada auditoria coordenada com o objetivo de avaliar as ações de governança das áreas protegidas brasileiras. Nesse sentido, entendeu-se ser necessária a adoção de medidas, pelo TCU, com vistas a aprimorar o controle externo sobre a ação governamental relativa à conservação das florestas, sobretudo no que concerne à governança ambiental das unidades de conservação. Havia a expectativa de que fosse construído um instrumento novo que comunicasse de forma clara o nível de gestão dos territórios protegidos. Desse modo, a proposta era que o projeto do TCU resultasse em um instrumento de avaliação sistemático 
dessa política pública que pudesse ser replicável pelas Entidades de Fiscalização Superior e, consequentemente, utilizado pela sociedade.

Para atender a essa demanda específica, foi elaborado o método Indimapa. Antes, porém de se desenvolver a ferramenta de avaliação Indimapa, criou-se um produto para fornecer os critérios e parâmetros balizadores da auditoria coordenada. Assim, elaborou-se um documento visual denominado Quadro de Normativos que apresenta um fluxograma das normas concernentes à governança das unidades de conservação e as suas inter-relações. Além disso, esse produto possibilita sistematizar as principais regras constitucionais, legais e infralegais que formam o arcabouço jurídico das áreas protegidas, o que permite a hierarquização e a identificação de lacunas, sobreposições e conflitos normativos.

Figura 3 - Quadro de Normativos

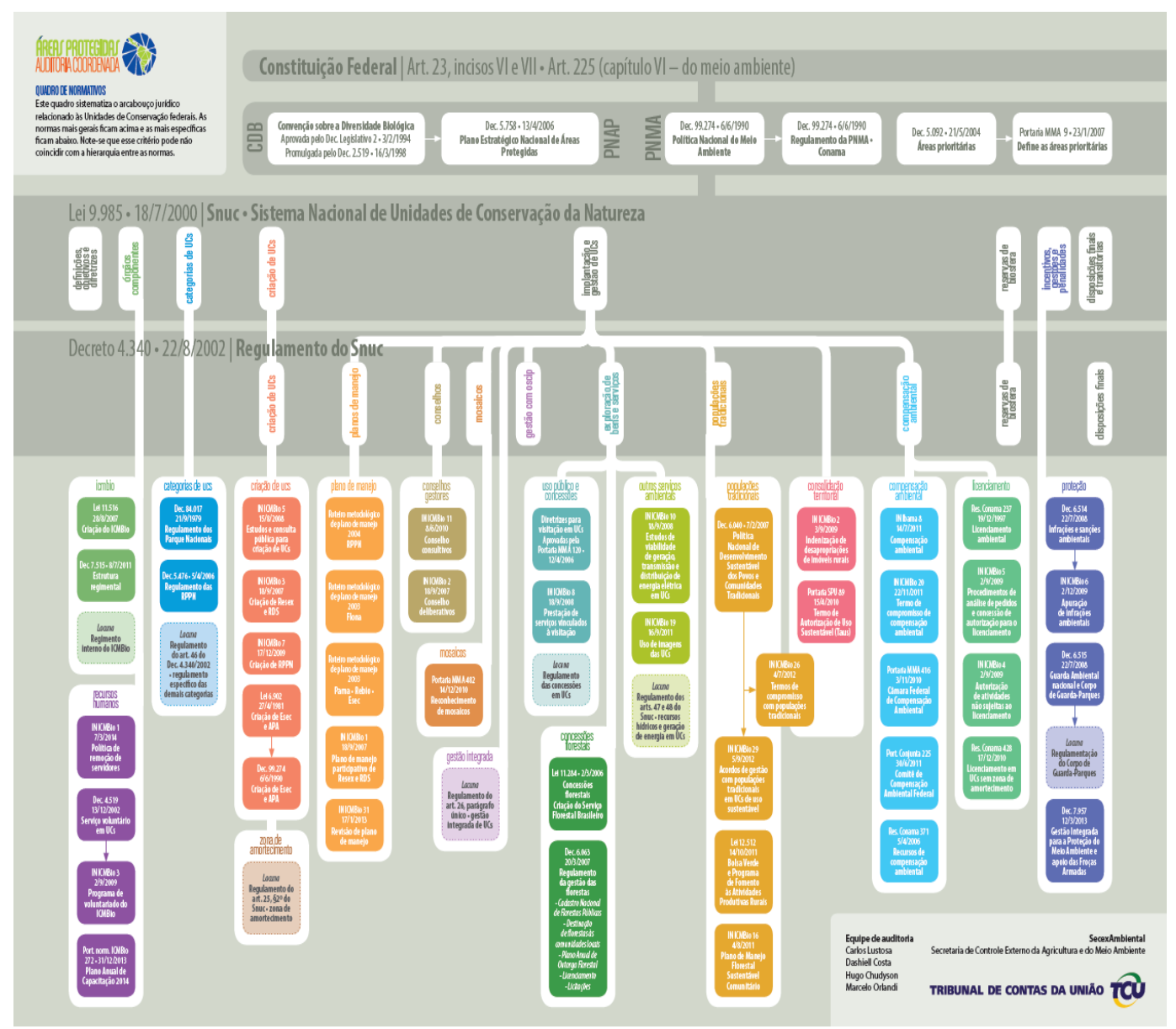

Fonte: TCU (2014)

A partir desse fluxograma, foi possível iniciar o processo de desenvolvimento do instrumento de avaliação, denominado Indimapa, o qual utiliza indicadores para aferir o desempenho da política pública ambiental, notadamente a gestão das áreas protegidas (APs), uma ação da política de conservação da biodiversidade. A ferramenta criada pelo TCU auxilia 
na avaliação da gestão destacando os pontos fortes e as fragilidades da política analisada, de forma a fornecer um panorama da ação governamental.

Os indicadores escolhidos para avaliar, sob a ótica do controle, a implementação e a gestão das APs foram construídos segundo alguns parâmetros. Inicialmente buscou-se incorporar critérios legais previstos no Sistema Nacional de Unidades de Conservação da Natureza (Lei 9.985/2000). Além disso, recorreu-se à metodologia Rappam (Rapid Assessment and Prioritization of Protected Areas Management), ferramenta internacionalmente reconhecida para avaliação da efetividade de áreas protegidas e que já analisou mais de 1600 áreas protegidas em 49 países em todo o mundo. (LEVERINGTON e HOCKINGS, 2010)

Por sua vez, a metodologia Management Effectiveness Tracking Tool (METT), elaborada pelo WWF em parceria com o Banco Mundial e baseada no modelo desenvolvido pela Comissão Mundial de Áreas Protegidas (CMAP) da UICN também foi consultada. O METT já foi aplicado em mais de 400 áreas protegidas em 50 países da Europa, Ásia, África e América Latina. Também serviu como referência o instrumento de avaliação desenvolvido pela Secretaria de Estado do Meio Ambiente e Desenvolvimento Sustentável do Estado do Amazonas (Indicadores de efetividade da implementação de unidades de conservação estaduais do Amazonas).

O Indimapa avalia 13 indicadores relativos ao desempenho da gestão das APs, aspecto imprescindível para o funcionamento adequado dessas áreas, o que possibilita o alcance dos resultados esperados quando de sua criação. Os indicadores utilizados estão dispostos no quadro a seguir.

Quadro 2 - Indicadores de Implementação e de Gestão de Áreas Protegidas

\begin{tabular}{|c|l|}
\hline Indicador & Tema \\
\hline G & Plano de manejo \\
\hline H & Recursos humanos \\
\hline $\mathbf{\$}$ & Recursos financeiros \\
\hline E & Estrutura administrativa \\
\hline T & Consolidação territorial \\
\hline F & Fiscalização e combate a emergências ambientais \\
\hline P & Pesquisa \\
\hline B & Monitoramento da biodiversidade \\
\hline
\end{tabular}




\begin{tabular}{|l|l|}
\hline C & Conselho gestor \\
\hline M & Manejo comunitário \\
\hline $\mathbf{U}$ & Uso público \\
\hline $\mathbf{N}$ & Concessões \\
\hline $\mathbf{L}$ & Articulação local \\
\hline
\end{tabular}

Devido às características singulares das APs, alguns dos indicadores são específicos para determinados grupos e categorias de AP, ou seja, nem todas essas áreas serão avaliadas por todos os 13 indicadores.

Os indicadores possuem escalas que variam de zero a três pontos para cada requisito. Desse modo, um ponto é atribuído por requisito alcançado. Atingidos os 3 requisitos, a AP recebe a pontuação máxima (3 pontos) e considera-se que aquela unidade atingiu, naquele aspecto, a situação esperada. Se nenhum dos requisitos é preenchido, a AP recebe pontuação zero (0 ponto) naquele aspecto, o que significa nenhum avanço na sua implementação.

Para superar a dificuldade de comparar diversos aspectos de gestão sem incorrer no risco de igualá-los, a solução encontrada foi o gráfico de radar. Esse tipo de gráfico permite comparar diferentes aspectos na medida em que demonstra a distância entre a uma situação existente e a situação esperada. Como consequência, em um único gráfico é possível se obter uma análise multidimensional.

Assim, conforme a seguir, para cada indicador há um eixo. Marca-se sobre cada eixo o ponto que representa o grau de implementação do aspecto. A linha formada pela ligação dos pontos dos eixos vizinhos forma um polígono. Esse polígono formado permite a identificação de picos e vales dentre os aspectos (isto é, forças e deficiências de gestão, respectivamente), bem como a situação geral da gestão da área protegida (mostrada pela expansão ou contração do polígono do gráfico sobre a teia de fundo).

Os indicadores foram representados num gráfico de radar para comunicar o grau de implementação e de gestão da AP avaliada. Nesse tipo de representação, quanto mais preenchido estiver o polígono e, consequentemente, mais próximo estiver da extremidade do gráfico, melhor será a avaliação da AP. Para demonstrar o gráfico de radar, é trazido um exemplo fictício que pode ser visualizado por meio da figura a seguir. 
Figura 4 - Exemplo de gráfico de radar com indicadores do Indimapa

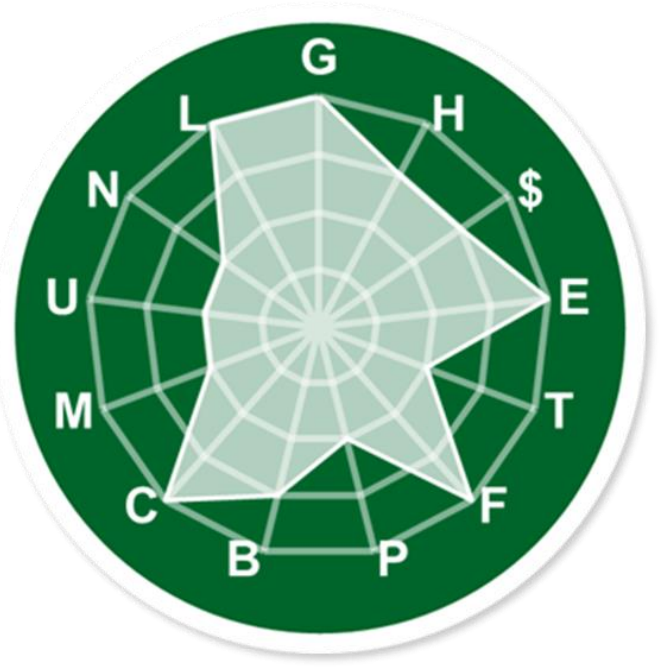

$\mathrm{G}$ - Plano de manejo

$\mathrm{H}$ - Recursos humanos

$\$$ - Recursos financeiros

E - Estrutura física

$\mathrm{T}$ - Consolidação territorial

F - Fiscalização ambiental

$\mathrm{P}$ - Pesquisa

B - Monitoramento da biodiversidade

$\mathrm{C}$ - Conselho gestor

M - Manejo comunitário

U - Uso público

$\mathrm{N}$ - Concessões

$\mathrm{L}$ - Articulação na área protegida

Fonte: TCU (2014)

Com intuito de otimizar a comunicação da avaliação dos indicadores de implementação e de gestão das APs avaliadas, optou-se por expô-los por meio de um mapa geográfico. Os resultados apresentados no Indimapa são a média dos 13 indicadores aplicáveis a cada AP avaliada, o que permite uma visualização do desempenho dessas áreas, ao classificá-las de forma individualizada em três faixas de cores: vermelha, amarela e verde.

A faixa vermelha vai até 0,99 pontos. Por sua vez, a escala amarela encontra-se entre 1 e 1,99. E, por fim, o verde significa a faixa de melhor índice, que vai de 2 a 3 pontos. Essa ferramenta consolida uma gama de informações sobre o conjunto das APs, bem como disponibiliza dados individualizados para cada um desses territórios, conforme se pode observar no caso das áreas protegidas da Amazônia brasileira. 
Mapa 1 - Indimapa Amazônia Brasileira

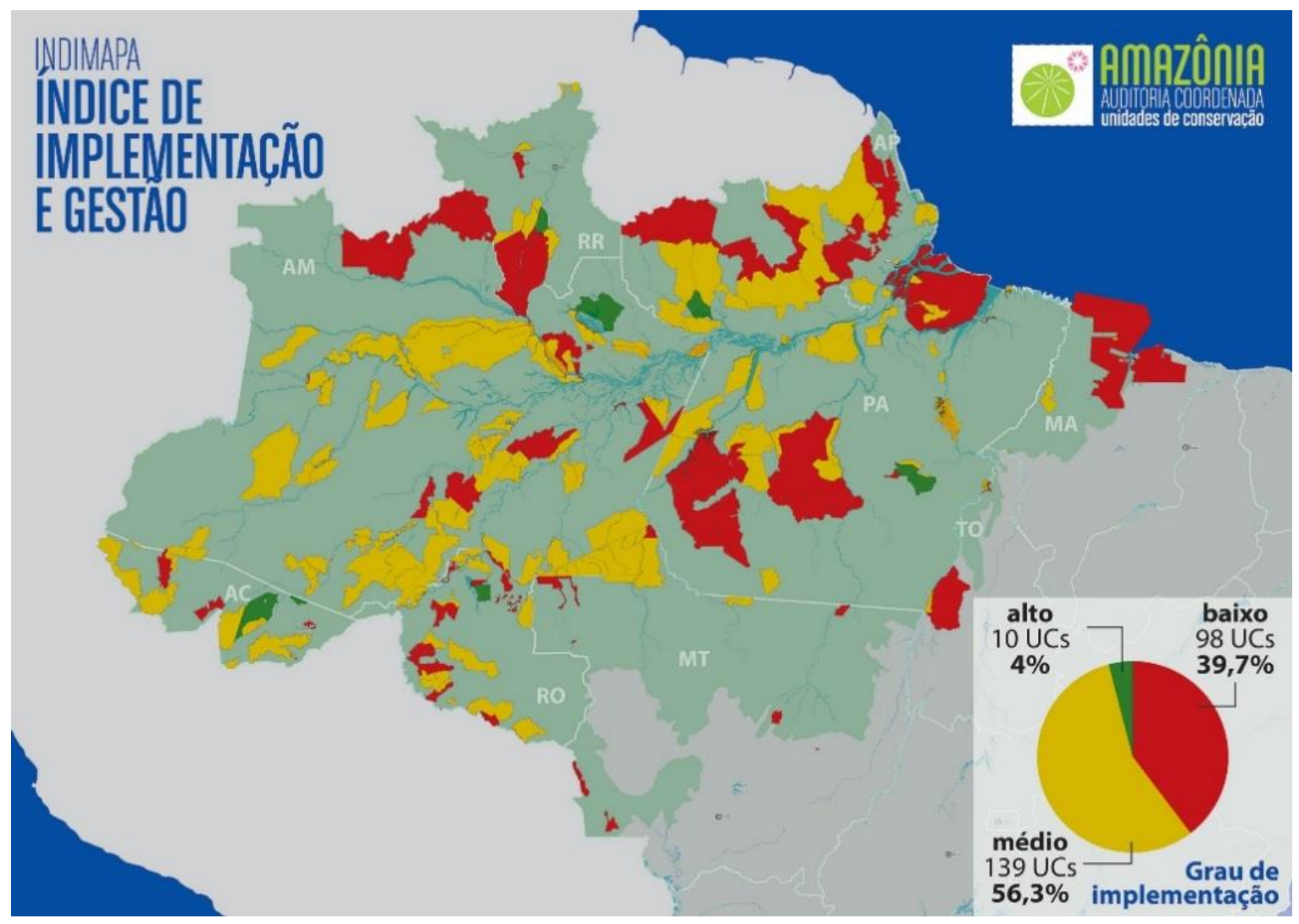

Fonte: TCU (2013)

De forma resumida, é possível assinalar que o Indimapa possibilita a identificação das UCs que mais necessitam de ações de implementação e de melhorias na gestão, atuando como ferramenta gerencial e estratégica. Além disso, esse instrumento permite o monitoramento da evolução da gestão dessas áreas por órgãos de controle, pelas entidades gestoras, por organizações não governamentais, por doadores internacionais e pela sociedade, aumentando, dessa maneira, o controle social e fortalecendo a governança do Sistema Nacional de Unidades de Conservação da Natureza.

Com a criação do Indimapa foi definida uma linha de base para futuras avaliações da gestão das UCs, o que proporcionará comparações cronológicas do desempenho da política pública de conservação da biodiversidade. Além disso, contribuirá para identificar áreas prioritárias para a realização de ações de controle externo. Desse modo, será possível que o TCU avalie se suas recomendações e determinações estão induzindo mudanças significativas para melhoria da atuação dessa ação governamental.

Adicionalmente, o Indimapa, ao disponibilizar uma visão sistêmica da política pública de áreas protegidas no Brasil, e, enquanto ferramenta de avaliação, comunicação e monitoramento, poderá subsidiar tecnicamente o processo de tomada de decisão que vise o 
alcance pleno dos objetivos daquela política, e, ainda, de outras políticas públicas relativas ao desenvolvimento da Amazônia, por exemplo.

Outro aspecto importante acerca do Indimapa a se ressaltar é a padronização e comparabilidade dos dados coletados. Considerando que a construção de uma visão sistêmica da política pública só é possível com a compilação de informações dos diferentes atores envolvidos, a necessidade de padronização e a comparabilidade de tais dados é uma consequência lógica.

Assim, a contribuição científica esperada para esta pesquisa é propiciar a sistematização desse método novo de avaliação da política pública relativa à gestão das unidades de conservação (UCs), visando ainda sanar esta lacuna identificada na literatura no que se refere à inovação no setor público, e contribuir também para as futuras avaliações a cargo do TCU.

Conforme o mapa estratégico do Tribunal, um aspecto que deve ser priorizado é desenvolvimento de uma cultura de inovação. Nesse sentido, busca-se aqui verificar se o Indimapa pode ser considerado uma inovação no TCU.

É preciso informar que, em 2014, o TCU coordenou trabalho conjunto que contou com a participação de 12 países latino-americanos. Nessa auditoria coordenada, também foi utilizado o Indimapa, o que permitiu avaliar 1120 UCs na América Latina. Participaram da fiscalização conjunta as Entidades de Fiscalização Superior da Argentina, Bolívia, Brasil, Colômbia, Costa Rica, Equador, El Salvador, Honduras, México, Paraguai, Peru e Venezuela, cujo resultado pode ser visto no mapa a seguir. 
Mapa 2 - Indimapa América Latina

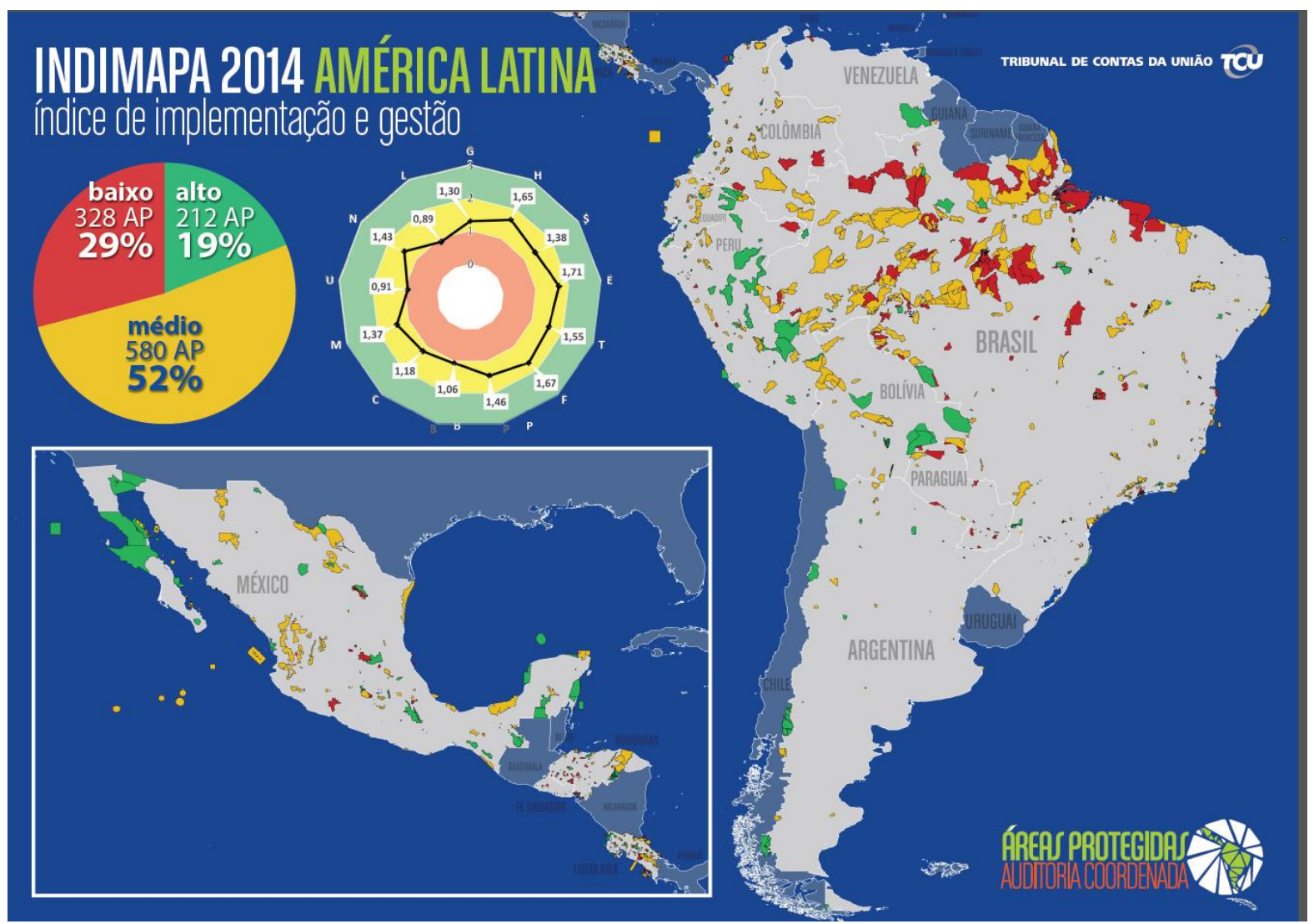

Fonte: TCU (2014)

Cabe destacar, ainda, que essa auditoria coordenada, por fazer parte do conjunto de ações previstas no Plano Operativo de Capacitação da OLACEFS, recebeu apoio financeiro da Agência Alemã para Cooperação Internacional (GIZ) no âmbito do projeto OLACEFS/GIZ para o desenvolvimento de parte de suas atividades.

O Indimapa é, portanto, um instrumento georreferenciado de avaliação, comunicação e monitoramento, visualizado por meio de um mapa do continente latino-americano. Essa ferramenta foi elaborada a partir de índices e indicadores de implementação e de gestão das 1120 APs avaliadas. Dessa maneira, dela se extraem dados individualizados da gestão de cada área protegida, assim como informações consolidadas das avaliações efetuadas pelo TCU e pelas 12 Entidades de Fiscalização Superior (EFS).

Assim, o Indimapa é uma ferramenta com três propósitos principais: servir como instrumento de diagnóstico individualizado por AP; ser um mecanismo de comunicação dos resultados da auditoria; e possibilitar um acompanhamento e monitoramento da implementação e da gestão das APs ao longo do tempo. Essa avaliação permite uma visão sistêmica da política pública de conservação da biodiversidade na América Latina, uma vez que se tem o resultado consolidado de todas as APs dessa região, de forma que é possível 
identificar numa rápida visualização os principais pontos fortes e fracos na gestão e implementação dessas áreas.

Diante do exposto, o presente trabalho visa analisar a influência do Indimapa sobre o desempenho organizacional do TCU, em especial quanto à comunicação dos resultados, à padronização na avaliação e ao monitoramento do objeto avaliado. Levando em consideração a necessidade de que o processo, medida ou atividade deve ter sido implementado para ser classificado como uma inovação, o estudo, que ora se realiza, pretende verificar se o método desenvolvido pelo Tribunal de Contas da União (TCU) para avaliar a política pública de conservação da biodiversidade pode ser classificado como uma inovação de serviços, com vistas a identificar a influência do instrumento sobre o desempenho organizacional do TCU. A seguir é apresentado um modelo que sintetiza a relação existente entre inovação de serviços e desempenho organizacional no contexto do TCU.

Figura 5: Modelo inovação de serviços e desempenho organizacional no TCU

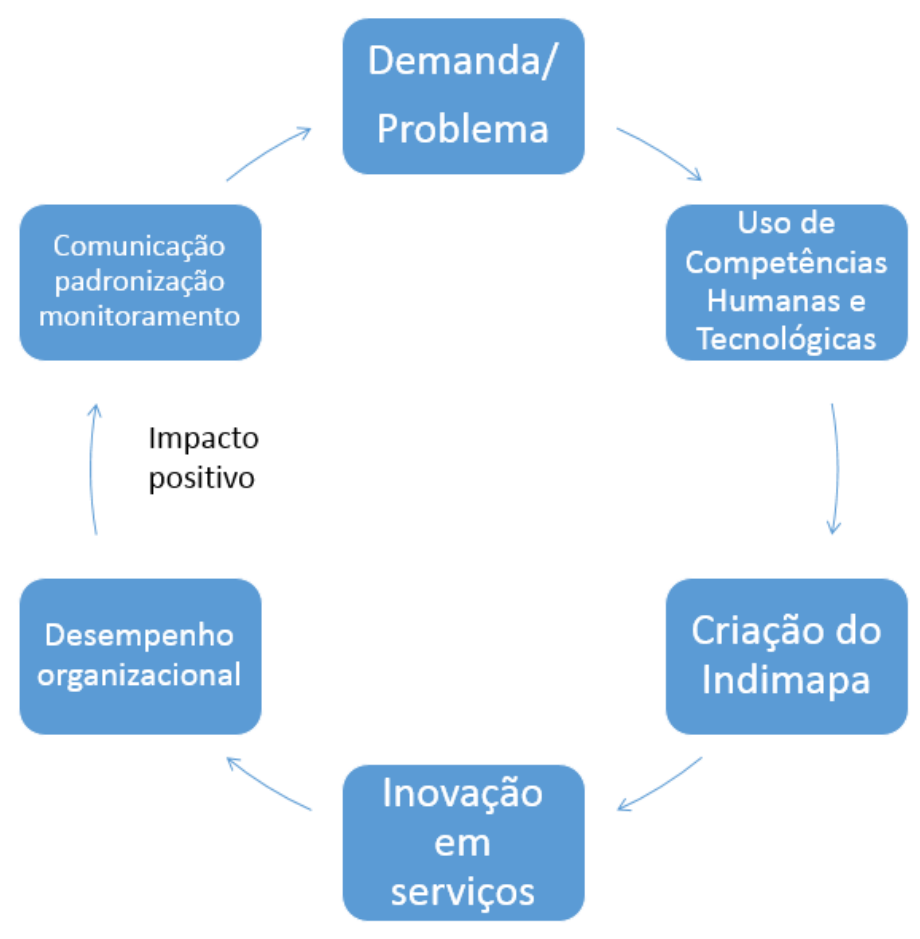

Fonte: elaborado pelo Autor

É preciso ressaltar que não se busca identificar barreiras no processo de inovação da auditoria tampouco fatores que contribuíram para que a inovação ocorresse. O foco está na caracterização do fenômeno inovador e sua influência para a melhoria do desempenho da instituição quanto ao monitoramento, à comunicação e à padronização na avaliação. Além disso, busca-se analisar se as bases conceituais do método elaborado pelo TCU podem ser 
aplicadas no processo de avaliação de outras políticas públicas pelo referido Órgão de Controle.

No capítulo subsequente serão apresentadas as características metodológicas da presente pesquisa sendo descritos os instrumentos e os procedimentos para coleta de dados, bem como serão detalhados os métodos utilizados no tratamento e análise dos dados. 


\section{4 - MÉTODO DE PESQUISA}

\subsection{ABORDAGEM DA PESQUISA}

O presente Capítulo descreve o método utilizado para a realização desta pesquisa, a qual possui caráter descritivo com abordagem qualitativa para obtenção e análise dos dados, com vistas a verificar se o Indimapa pode ser caracterizado como uma inovação de serviços, e, em caso positivo, de que forma influencia o desempenho organizacional do Tribunal de Contas da União (TCU).

\subsection{AMOSTRA E DESCRIÇÃO DA PESQUISA}

O estudo é caracterizado como pesquisa aplicada, transversal, descritiva, com abordagem qualitativa, cujo procedimento técnico é a análise do Indimapa como estudo de caso (YIN, 2010), utilizando-se de dados primários. Destaca-se que os dados foram obtidos através de relatos (entrevistas estruturadas) e de forma documental por meio da análise das auditorias coordenadas realizadas pelo TCU em conjunto com outras Entidades Fiscalizadoras Superiores (EFS) e com outros Tribunais de Contas Estaduais. A amostra foi estratificada e intencional. Foram analisados os relatórios de auditoria e os mecanismos de divulgação de resultados utilizados em tais fiscalizações.

A amostra foi formada por seis auditorias coordenadas que trataram dos seguintes temas: a) Ensino Médio - auditoria nacional; b) Segurança Pública - auditoria nacional; c) Recursos Hídricos - auditoria internacional; d) Programa de Ação Mercosul Livre de Febre Aftosa - auditoria internacional; e) Mudanças Climáticas - auditoria internacional; e f) Atenção Básica à Saúde - auditoria nacional. Já o intervalo temporal de análise da pesquisa foi definido entre 2011 e 2015, por ser o período em que se concentra a realização das auditorias coordenadas, em especial os trabalhos conjuntos internacionais.

\subsection{PROCEDIMENTOS DE COLETA DE DADOS}

Inicialmente foi feita uma busca na base de dados do TCU (site), no período de 2011 a 2015, utilizando como elementos de pesquisa as palavras-chave: geoprocessamento, georreferenciamento, criação de indicadores, mapas georreferenciados, comunicação dos resultados e práticas e ferramentas ou instrumentos inovadores.

Em seguida, avaliou-se a frequência da ocorrência dos termos citados com vistas a realizar a classificação estabelecida pelo Manual de Copenhagen (MEPIN, 2011), qual seja: 
inovação de produto, inovação de processo, inovação organizacional e inovação de comunicação.

Além disso, foram analisados os relatórios das auditorias coordenadas mencionadas anteriormente, os quais foram obtidos por meio do site do TCU. Foram analisadas as etapas de planejamento, execução e resultados visando identificar a elaboração pela equipe de auditoria de produtos que tenham abordado os seguintes aspectos: geoprocessamento, indicadores, dados consolidados, mapas, comunicação e inovação. Com esse procedimento buscou-se analisar as formas alternativas de comunicação dos resultados das auditorias, além do voto, relatório e acórdão.

Adicionalmente, utilizou-se um roteiro de entrevista com questões estruturadas submetido a seis auditores do TCU que, por terem se manifestaram na apreciação do processo da auditoria ou que, embora não tenham se manifestado oficialmente, tomaram conhecimento do Indimapa, eram as pessoas mais envolvidas com o objeto analisado. As entrevistas visaram colher subsídios para identificar como o Indimapa foi percebido no processo de trabalho de auditorias e se o método criado podia ser considerado uma inovação de serviços no âmbito do Tribunal de Contas da União.

As entrevistas foram agendadas previamente e realizadas no local de trabalho do entrevistado com uma duração média de 60 minutos. A ferramenta foi aplicada individualmente, precedida de uma explicação a respeito do tema e da relevância da pesquisa e gravada, mediante autorização de cada entrevistado, para que fosse possível a posterior transcrição e análise das respostas. Cumpre mencionar também o perfil dos participantes que forneceram os dados necessários para a realização da pesquisa proposta.

\subsection{PERFIL DE PARTICIPANTES NA ENTREVISTA}

Para ilustrar o perfil dos entrevistados, foi elaborado quadro com a quantidade de servidores entrevistados, cargos ocupados e tempo de experiência no Tribunal de Contas da União.

Quadro 3 - Perfil dos entrevistados

\begin{tabular}{|l|l|l|}
\hline Quantidade & \multicolumn{1}{|c|}{ Cargo } & \multicolumn{1}{|c|}{ Tempo de experiência } \\
\hline 1 & $\begin{array}{l}\text { Secretário de Controle Externo da Agricultura e } \\
\text { do Meio Ambiente }\end{array}$ & Entre 15 e 20 anos \\
\hline 2 & Secretário de Relações Internacionais & Entre 15 e 20 anos \\
\hline 3 & Diretor da Secretaria de Controle Externo da & Entre 15 e 20 anos \\
\hline
\end{tabular}




\begin{tabular}{|l|l|l|}
\hline & Agricultura e do Meio Ambiente & \\
\hline 4 & $\begin{array}{l}\text { Secretário de Métodos Aplicados e Suporte à } \\
\text { Auditoria }\end{array}$ & Entre 15 e 20 anos \\
\hline 5 & Secretário Geral de Controle Externo do TCU & Entre 15 e 20 anos \\
\hline 6 & Assessor do Ministro Relator & Entre 15 e 20 anos \\
\hline
\end{tabular}

Fonte: elaborado pelo Autor

Cabe destacar que os temas utilizados para a elaboração do roteiro de questões submetidas aos entrevistados levaram em consideração o referencial teórico estudado e o objeto avaliado (Indimapa). Ressalte-se ainda que se buscou conferir um ordenamento partindo do assunto que tivesse maior abrangência até se chegar às características da ferramenta Indimapa.

\subsection{ANÁLISE DAS ENTREVISTAS}

Para compilação e interpretação dos resultados das entrevistas, utilizou-se análise de conteúdo, conforme Bardin (1977), em que foram estabelecidas categorias de forma a permitir uma comparação entre as características avaliadas. A análise de conteúdo pode ser entendida como "um conjunto de técnicas de análise das comunicações visando obter, por meio de procedimentos sistemáticos e objetivos, indicadores (quantitativos ou não) que permitam a inferência de conhecimentos relativos às condições de produção/recepção das mensagens" (BARDIN, 1977, p. 44). Portanto, esta técnica propõe analisar o que é explícito no texto a fim de obter indicadores que permitam fazer inferências.

Para analisar as entrevistas realizadas foi preciso, de início, organizar os dados e, posteriormente, ordená-los em categorias, permitindo, dessa forma, classificar, agregar e categorizar as informações do conteúdo obtido. As categorias definidas são: análise multidimensional; georreferenciamento das informações; comunicação do resultado; padronização da avaliação; comparabilidade de resultados; formas de monitoramento; utilização de produtos visuais.

A análise de conteúdo requer a elaboração de categorias de análise, conforme ensina Franco (2004). Vale mencionar que a criação de categorias pode seguir critérios diferenciados. No caso em tela, as categorias foram estabelecidas a priori, levando em conta os objetivos específicos da presente pesquisa.

Ainda em relação à análise das entrevistas, foram identificados parâmetros comuns entre elas, de forma a identificar o fenômeno da inovação por meio da avaliação da auditoria 
coordenada e, principalmente, do Indimapa. Para Koch e Haucknes (2005), existe uma lacuna no que diz respeito a um método adequado para compreender e medir inovação no setor público. Visando superar essa dificuldade, foi criada uma matriz de análise com qual foi possível verificar como as auditorias coordenadas foram realizadas comparando com o método utilizado na Auditoria em Áreas Protegidas. Adicionalmente, almejou-se identificar a influência do Indimapa sobre o desempenho organizacional do TCU. Para isso, foram listados os produtos gerados e, principalmente, os benefícios esperados em decorrência da utilização do método Indimapa. Assim, o desempenho organizacional do TCU foi analisado levando em consideração os seguintes critérios: Formas de monitoramento; Comunicação dos resultados; Utilização de indicadores; Padronização na avaliação. Analisou-se a contribuição do Indimapa nesses quesitos, conforme Matriz de Análise, realizando-se a triangulação entre as informações provenientes das entrevistas com os dados obtidos no site do TCU e nos relatórios de auditorias coordenadas.

Quadro 4 - Exemplo de Matriz de Análise das auditorias

\begin{tabular}{|c|c|c|c|c|}
\hline & $\begin{array}{c}\text { Como foi feito } \\
\text { nas auditorias } \\
(2011 \text { a 2015) }\end{array}$ & $\begin{array}{l}\text { Como foi feito na } \\
\text { auditoria em } \\
\text { áreas protegidas }\end{array}$ & $\begin{array}{c}\text { Produtos } \\
\text { gerados }\end{array}$ & $\begin{array}{l}\text { Benefícios } \\
\text { esperados }\end{array}$ \\
\hline $\begin{array}{ll}\text { Formas } & \text { de } \\
\text { monitoramento } & \end{array}$ & & & & \\
\hline $\begin{array}{l}\text { Comunicação dos } \\
\text { resultados }\end{array}$ & & & & \\
\hline $\begin{array}{ll}\text { Utilização } & \text { de } \\
\text { indicadores } & \end{array}$ & & & & \\
\hline $\begin{array}{l}\text { Padronização na } \\
\text { avaliação }\end{array}$ & & & & \\
\hline
\end{tabular}

Fonte: elaborado pelo Autor

Nessa linha, a partir dos dados referentes às entrevistas, utilizou-se a referida matriz com os indutores de inovação de serviços e, dessa forma, foi feita uma relação com a teoria levantada no referencial teórico para compreender a teoria e a prática. Com o intuito de sintetizar as informações relativas a este capítulo, foi produzido um quadro resumo em que é possível visualizar os procedimentos metodológicos usados no presente trabalho, os objetivos de pesquisa, a abordagem utilizada, bem como o referencial teórico e as técnicas de coleta e análise de dados. 
Quadro 5 - Procedimentos metodológicos utilizados

\begin{tabular}{|c|c|c|c|}
\hline \multicolumn{4}{|c|}{ Tema, Fenômeno, Pergunta e Objetivos da pesquisa } \\
\hline Tema & \multicolumn{3}{|c|}{ Inovação de serviços e desempenho organizacional } \\
\hline $\begin{array}{l}\text { Pergunta de } \\
\text { pesquisa }\end{array}$ & \multicolumn{3}{|c|}{$\begin{array}{l}\text { O Indimapa pode ser caracterizado como uma inovação de serviços, e, em caso } \\
\text { positivo, de que forma ele influencia o desempenho organizacional do TCU? }\end{array}$} \\
\hline Objetivo geral & \multicolumn{3}{|c|}{$\begin{array}{c}\text { Verificar se o Indimapa pode ser caracterizado como uma inovação de serviços, } \\
\text { e, em caso positivo, de que forma influencia o desempenho organizacional do } \\
\text { TCU }\end{array}$} \\
\hline Lócus da pesquisa & \multicolumn{3}{|c|}{ Tribunal de Contas da União (TCU) } \\
\hline $\begin{array}{l}\text { Objetivos } \\
\text { específicos }\end{array}$ & $\begin{array}{c}\text { Identificar os indutores } \\
\text { de inovação de serviços } \\
\text { no Indimapa }\end{array}$ & $\begin{array}{c}\text { Identificar a influência do } \\
\text { Indimapa sobre a } \\
\text { comunicação dos } \\
\text { resultados das auditorias } \\
\text { do Tribunal de Contas da } \\
\text { União (TCU), sobre o } \\
\text { processo de } \\
\text { monitoramento e a } \\
\text { padronização na avaliação } \\
\text { do objeto auditado no } \\
\text { âmbito das auditorias do } \\
\text { TCU } \\
\end{array}$ & $\begin{array}{l}\text { Verificar se o Indimapa } \\
\text { pode ser classificado } \\
\text { como inovação de } \\
\text { produto, inovação de } \\
\text { comunicação, inovação } \\
\text { organizacional e } \\
\text { inovação de processo } \\
\text { no âmbito do TCU }\end{array}$ \\
\hline \multicolumn{4}{|c|}{ Operacionalização da pesquisa } \\
\hline \multirow{10}{*}{$\begin{array}{l}\text { Referencial } \\
\text { teórico }\end{array}$} & $\begin{array}{c}\text { Inovação de serviços e } \\
\text { desempenho } \\
\text { organizacional }\end{array}$ & $\begin{array}{c}\text { Inovação de serviços e } \\
\text { desempenho } \\
\text { organizacional }\end{array}$ & $\begin{array}{l}\text { Desempenho no setor } \\
\text { público }\end{array}$ \\
\hline & Gallouj (2007) & Salazar; Holbrook (2004) & $\begin{array}{l}\text { Walker; Damanpour; } \\
\text { Devece (2010) }\end{array}$ \\
\hline & Schumpeter (1934) & Mulgan; Albury (2003) & Bloch (2010) \\
\hline & $\begin{array}{l}\text { OCDE (2005) - manual } \\
\text { de Oslo }\end{array}$ & Walker (2006 e 2007) & $\begin{array}{l}\text { Dantas; Queiroz; } \\
\text { Queiroz (2010) }\end{array}$ \\
\hline & Mulgan; Albury (2003) & $\begin{array}{l}\text { Damanpour; Walker; } \\
\text { Avellaneda (2009) }\end{array}$ & Warin (1997) \\
\hline & Sundbo; Gallouj (1998) & $\begin{array}{c}\text { Birkinshaw; Hamel; Mol } \\
\text { (2008) }\end{array}$ & Gespublica (2010) \\
\hline & $\begin{array}{l}\text { Gallouj; Weinstein } \\
\text { (1997) }\end{array}$ & $\begin{array}{l}\text { Vigoda-Gadot e } \\
\text { colaboradores (2008) }\end{array}$ & Guzmán (1991) \\
\hline & Sundbo (2003) & Koch; Hauknes (2005) & Grateron (1999) \\
\hline & $\begin{array}{l}\text { Carayannis; Gonzalez; } \\
\text { Wetter (2003) }\end{array}$ & $\begin{array}{l}\text { Mepin (2011) - manual de } \\
\text { Copenhagen }\end{array}$ & \multirow[t]{2}{*}{ OCDE (2010) } \\
\hline & $\begin{array}{c}\text { Birkinshaw; Hamel; Mol } \\
\text { (2008) }\end{array}$ & $\begin{array}{c}\text { União Europeia - EPSIS } \\
(2013)\end{array}$ & \\
\hline $\begin{array}{c}\text { Abordagem } \\
\text { (RICHARDSON, } \\
\text { 2010) } \\
\end{array}$ & Qualitativa & Qualitativa & Qualitativa \\
\hline $\begin{array}{c}\text { Escolha dos } \\
\text { participantes }\end{array}$ & \multicolumn{3}{|c|}{ Por conveniência } \\
\hline $\begin{array}{l}\text { Técnica para } \\
\text { coleta dos dados } \\
\text { (RICHARDSON, } \\
\text { 2010) } \\
\end{array}$ & Levantamento de dados & $\begin{array}{l}\text { Levantamento de dados e } \\
\text { entrevista }\end{array}$ & $\begin{array}{l}\text { Levantamento de dados } \\
\text { e entrevista }\end{array}$ \\
\hline Técnica para & Análise de conteúdo & Análise de conteúdo e & Análise de conteúdo e \\
\hline
\end{tabular}




\begin{tabular}{|c|c|c|} 
análise de dados & estatística descritiva & estatística descritiva \\
\hline $\begin{array}{c}\text { Categorias de } \\
\text { análise (BARDIN, } \\
\text { 1977) }\end{array}$ & Inovação de serviços, Comunicação de resultados, Monitoramento, \\
Padronização, Consolidação
\end{tabular}

Fonte: elaborado pelo Autor

Após a interpretação dos dados, a apresentação e discussão dos resultados ocorreu tendo como base o arcabouço teórico abordado no presente trabalho, conforme poderá ser visto a seguir. 


\section{4 - RESULTADOS E DISCUSSÃO}

Este capítulo visa apresentar os dados colhidos nesta pesquisa e busca discutir os resultados encontrados tendo como base as informações obtidas na coleta de dados e as análises efetuadas, levando em consideração, ainda, o referencial teórico deste trabalho. Para tanto, o presente capítulo foi divido em quatro seções, começando pelos resultados da pesquisa realizada no banco de dados do TCU (site). Em segundo lugar, são apresentadas as características das cinco auditorias analisadas em contraste com a auditoria em áreas protegidas. Na terceira seção, são abordadas as respostas coletadas por meio do roteiro de entrevista. Na quarta e última seção, a matriz de análise consolida as informações coletadas das diversas fontes e traz as diferenças e os impactos provenientes do Indimapa sobre os processos de trabalho das auditorias no TCU, o que permitirá identificar a influência do desse instrumento no desempenho organizacional daquela organização.

\subsection{Pesquisa realizada no banco de dados do TCU (site)}

De início, vale informar que o banco de dados do TCU possui um acervo de mais de 200 mil resultados com informações digitalizadas desde o período de 1992 até os dias de hoje. Nesse sentido, buscou-se identificar nas auditorias do TCU a frequência com que são utilizados determinados procedimentos, técnicas e atividades. Assim, as palavras-chave escolhidas para serem pesquisadas no banco de dados do TCU (site) foram: geoprocessamento, georreferenciamento, criação de indicadores, mapas georreferenciados, comunicação dos resultados e práticas e ferramentas ou instrumentos inovadores. Já a delimitação temporal ficou restrita ao período de 2011 a 2015, conforme definição do escopo da dissertação.

Em função dos objetivos de pesquisa e das características intrínsecas à atividade de auditoria, só foram consideradas na amostra selecionada as fiscalizações do tipo auditoria, excluindo os processos relativos à prestação de contas, denúncia, representação, monitoramento, levantamento, solicitação do Congresso Nacional, tomada de contas especial e acompanhamento.

É preciso mencionar ainda que a pesquisa não se restringiu as sete auditorias coordenadas que serviram para comparação com a auditoria em áreas protegidas, as quais serão tratadas na seção seguinte. Por fim, cabe destacar que a auditoria em áreas protegidas foi excluída da amostra, uma vez que ela é objeto de estudo dessa pesquisa científica. A seguir são apresentados os resultados encontrados. 


\subsubsection{Geoprocessamento}

Data: Pesquisa realizada em 22/7/2015

Dados: Retornaram 104 resultados, sendo 34 em auditorias. Nesses, 7 foram realizadas antes de 2011, levando à exclusão desses trabalhos, o que resultou em 27 relatórios de auditoria. Ao analisar os 27 relatórios, verificou-se que em nenhuma auditoria foram utilizados pelas equipes técnicas do TCU mecanismos de geoprocessamento em nenhuma das fases do trabalho de fiscalização.

\subsubsection{Georreferenciamento}

Data: Pesquisa realizada em 22/7/2015

Dados: Retornaram 123 resultados, sendo que 37 haviam sido realizados antes de 2011, o que resultou em 87 processos, sendo 37 de auditorias. Ao avaliar os 37 relatórios, verificou-se que em nenhuma auditoria foram utilizados pelas equipes técnicas do TCU mecanismos de georreferenciamento em nenhuma fase do trabalho.

\subsubsection{Criação de indicadores}

Data: Pesquisa realizada em 23/7/2015

Dados: Retornaram 38 resultados, sendo que 13 haviam sido realizados antes de 2011, o que resultou em 25 processos, sendo 14 de auditorias. Ao avaliar os 14 relatórios, verificou-se que em nenhuma auditoria foram elaborados pelas equipes técnicas do TCU indicadores em nenhuma etapa da auditoria.

\subsubsection{Práticas, ferramentas, instrumentos inovadores}

Data: Pesquisa realizada em 12/8/2015

Dados: Nenhum resultado foi encontrado.

\subsubsection{Comunicação dos resultados}

Data: Pesquisa realizada em 12/8/2015

Dados: Retornaram 59 resultados, sendo que 34 haviam sido realizados antes de 2011, o que resultou em 25 processos, sendo 7 de auditorias. Ao avaliar os 7 relatórios, verificou-se que em nenhum desses processos a comunicação dos resultados estava relacionada aos resultados da auditoria, tampouco a formas alternativas de divulgação das conclusões obtidas. 


\subsubsection{Mapas georreferenciados}

Data: Pesquisa realizada em 12/8/2015

Dados: Retornaram 6 resultados, porém, em nenhum desses processos, verificou-se a utilização de mapas georreferenciados como forma de comunicação, avaliação ou monitoramento.

Da análise dos dados anteriores, pode-se notar que são muito raras e, até mesmo inexistentes, as atividades de fiscalização que tenham envolvido procedimentos e técnicas como geoprocessamento, georreferenciamento, criação de indicadores, mapas georreferenciados. Observa-se, portanto, que tais atividades aparecem como práticas isoladas e pontuais, o que indica, do ponto de vista organizacional, a frágil incorporação e baixa utilização desses mecanismos no âmbito das auditorias do TCU.

Além disso, importa destacar que um dos procedimentos metodológicos da presente pesquisa visa efetuar uma análise em relação à frequência da ocorrência dos termos citados, no entanto, em função dos resultados obtidos, não foi possível realizar tal avaliação, tampouco a classificação em: inovação de produto, inovação de processo, inovação organizacional e inovação de comunicação.

\subsection{Análise dos relatórios de auditoria}

Nesta seção são apresentados os resultados da análise dos relatórios das seis auditorias coordenadas selecionadas os quais foram analisados com vistas a identificar procedimentos, técnicas e atividades que tenham utilizado geoprocessamento, indicadores, dados consolidados, mapas, comunicação e inovação. Ao comparar tais fiscalizações com a auditoria em áreas protegidas, também se buscou nesse procedimento avaliar as formas alternativas de comunicação dos resultados das auditorias, além do voto, relatório e acórdão. A seguir os resultados da análise de cada uma das auditorias são apresentados.

\subsubsection{Auditoria Coordenada no Ensino Médio}

Essa auditoria visava identificar os principais problemas que afetam a qualidade e a cobertura do ensino médio no Brasil, bem como pretendia avaliar as ações governamentais que procuram eliminar ou mitigar as causas de tais problemas. A auditoria, realizada em 2013, teve como foco o ensino médio regular, de forma que a Educação de Jovens e Adultos (EJA) e o ensino médio profissional foram tratados de modo complementar.

Além do TCU como coordenador da fiscalização, por ser um trabalho de âmbito 
nacional, houve a participação de 28 Tribunais de Contas Estaduais de todo o Brasil. Integraram a fiscalização: o Tribunal de Contas da União; os Tribunais de Contas dos Estados do Acre, Alagoas, Amapá, Amazonas, Bahia, Ceará, Espírito Santo, Goiás, Maranhão, Minas Gerais, Mato Grosso, Mato Grosso do Sul, Pará, Paraíba, Pernambuco, Piauí, Paraná, Rio de Janeiro, Rio Grande do Norte, Rondônia, Rio Grande do Sul, Santa Catarina, Sergipe e Tocantins; o Tribunal de Contas do Distrito Federal; os Tribunais de Contas dos Municípios da Bahia e do Pará; o Tribunal de Contas do Município de São Paulo.

Nesse tipo de trabalho conjunto, denominado de auditorias coordenadas, as fiscalizações são executadas simultaneamente por "diferentes instituições, que ajustam um tema, adotam a mesma metodologia e compartilham o planejamento. Ao final do trabalho, em adição ao relatório individual de cada tribunal participante, é feito um relatório comum, consolidando informações dos trabalhos individuais" (TCU, 2014, p. 2).

De forma resumida, é possível dizer que os resultados encontrados apontaram a necessidade de melhoria a ser obtida com a atuação coordenada e coerente dos sistemas de planejamento e orçamento público; de administração financeira; de controles internos; de gestão de risco; de monitoramento e avaliação de políticas públicas; e de prestação de contas.

Nesse trabalho utilizou-se de elementos gráficos, a exemplo de mapas geográficos, para demonstrar, por exemplo, a análise do déficit de vagas potenciais, em 2016, por município, o que indicou a necessidade de construção de novas salas de aula alocadas ao ensino médio na rede estadual pública de ensino. Assim, concluiu-se que a análise de cobertura deve ser referenciada geograficamente, levando-se em conta a distribuição da população a ser atendida e a localização das escolas e problematizada territorialmente envolvendo mecanismos de cooperação horizontal (de estado para estado) e vertical (da União para os estados).

Embora tenha lançado mão da utilização de mapas geográficos, a auditoria no ensino médio não usou mapas georreferenciados como uma forma de avaliação e comunicação dos resultados obtidos, apenas como um instrumento visual sem uma análise crítica a respeito do objeto avaliado.

Por fim, vale destacar que, para comunicar os resultados da auditoria coordenada no ensino médio, foram elaborados o relatório técnico, o voto do Ministro Relator e o Acórdão do TCU. Além disso, também foi produzido um sumário executivo que consolida os principais resultados da fiscalização conjunta. 


\subsubsection{Auditoria Coordenada em Mudanças Climáticas}

A auditoria coordenada em mudanças climáticas tinha por objetivo avaliar as ações governamentais no que diz respeito à implementação dos compromissos estabelecidos na Convenção-Quadro das Nações Unidas sobre mudança do clima, a fim de produzir um relatório que contribuísse com uma gestão eficaz para resolver o problema das alterações climáticas na região. A referida auditoria, realizada em âmbito internacional no ano de 2009, contou com a participação de nove Entidades Superiores de Fiscalização (EFS) dos seguintes países: Argentina, Brasil, Colômbia, Costa Rica, El Salvador, Honduras, Panamá, Paraguai e Peru.

Os resultados deste trabalho internacional indicaram que as ações das instituições governamentais dos países participantes da auditoria ainda são insuficientes para lidar com a mudança climática, e que os países estão pouco preparados para enfrentar os desafios impostos pelas mudanças do clima. Além disso, conclui-se que não existem mecanismos de avaliação e acompanhamento específico sobre a implementação dos avanços em medidas de adaptação e de mitigação das mudanças climáticas e que os controles estabelecidos pelas entidades responsáveis são frágeis. Como resultado, não pode ser medida a eficácia e a eficiência das atividades constantes das políticas, estratégias ou planos, bem como a realização dos objetivos propostos para esta finalidade.

Nesta fiscalização, não foram utilizados mecanismos de georreferenciamento para avaliar e/ou comunicar os resultados das análises empreendidas, tampouco se lançou mão de indicadores que pudessem trazer dados objetivos sobre a política pública avaliada. Por último, cumpre mencionar que, além do relatório técnico, do voto do Ministro Relator e do Acórdão do TCU, também foi elaborado um sumário executivo que aborda as constatações mais relevantes dessa auditoria coordenada.

\subsubsection{Auditoria Coordenada no Programa de Ação Mercosul Livre de Febre}

\section{Aftosa (PAMA)}

A auditoria coordenada com membros da Organização das Entidades Fiscalizadoras Superiores do Mercosul e Associados (EFSUL) contou com a participação das Entidades Superiores de Fiscalização da Argentina, Bolívia, Brasil e Paraguai, e teve como finalidade avaliar o Programa de Ação Mercosul Livre de Febre Aftosa (PAMA).

Buscou-se analisar o PAMA em relação ao combate à febre aftosa e se os recursos utilizados no programa estavam sendo controlados e acompanhados adequadamente, visando identificar em ambos os casos pontos que possam aperfeiçoar sua gestão atual e futura. 
Esse trabalho, de caráter internacional, ocorrido em 2012, chegou à conclusão de que não existiam, à época, planejamentos de médio e longo prazo, nem estudos técnicos de abrangência regional capazes de orientar as ações que teriam maior impacto para o atingimento dos objetivos do programa. Também se verificou que não se utilizavam, de forma sistemática, indicadores de desempenho para acompanhar, avaliar e reorientar as atividades do PAMA.

Apesar de se tratar de um trabalho coordenado que envolveu diferentes órgãos de controle e diversos países, da análise do relatório não é possível extrair dados que ofereçam um panorama regional sobre a política pública avaliada. Com efeito, observa-se um foco maior nas ações governamentais brasileiras em detrimento a uma visão sistêmica do objeto analisado. Aliado a este fato, nota-se a ausência da utilização de indicadores e de dados georreferenciados.

Da mesma forma que as demais fiscalizações retroavaliadas, a auditoria coordenada no PAMA igualmente produziu um sumário executivo com vistas a divulgar as constatações das Entidades de Fiscalização Superior, ademais de contar com o do relatório técnico, do voto do Ministro Relator e do Acórdão do TCU.

\subsubsection{Auditoria Coordenada em Recursos Hídricos}

O objetivo geral desta fiscalização foi examinar a gestão dos estados nacionais da região latino-americana para garantir o uso sustentável do recurso hídrico, e verificar se os instrumentos de gestão aplicados garantiam a sustentabilidade do recurso hídrico. As 11 Entidades de Fiscalização Superiores (EFS) participantes da auditoria coordenada foram: Argentina, Brasil, Chile, Colômbia, Costa Rica, Cuba, Honduras, México, Paraguai, Peru e Venezuela.

As EFS constataram uma fragmentação da organização institucional com uma consequente sobreposição de funções e falta de articulação entre os organismos governamentais envolvidos. Além disso, verificaram a falta de definição de objetivos e metas claras e quantificáveis referentes à quantidade e à qualidade dos recursos hídricos, e, também, a ausência de indicadores para medir seu desempenho.

Em que pesem tais constatações, ao analisar o relatório de auditoria, verifica-se que o trabalho realizado não teve como característica apresentar um diagnóstico em nível regional que possibilitasse saber o nível de gestão dos recursos hídricos no continente avaliado. Em verdade, tem-se uma compilação de dados, com informações agregadas, porém sem necessariamente oferecer um panorama do problema analisado. 
Neste caso, também se elaborou um sumário executivo a fim de comunicar o resultado do trabalho, o qual foi acompanhado das peças técnicas obrigatórias, quais sejam, relatório técnico, voto do Ministro Relator e Acórdão do TCU.

\subsubsection{Auditoria Coordenada em Segurança Pública}

Para a realização da auditoria coordenada em segurança pública, estabeleceu-se como objetivo avaliar as condições de governança e de gestão da Secretaria Nacional de Segurança Pública (Senasp) e das organizações de segurança pública dos estados e do Distrito Federal (OSPE), geralmente denominadas secretarias de segurança pública, em especial quanto às condições de implementação da Política Nacional de Segurança Pública.

Adicionalmente, foi analisado se os bens adquiridos com recursos do governo federal, estavam sendo efetivamente utilizados no fim proposto e/ou adequadamente mantidos, bem como foi verificado se o ente estatal dispunha de recursos humanos e materiais suficientes para uma boa gestão.

O trabalho, realizado em 2014, teve abrangência nacional e permitiu apresentar os resultados preliminares da avaliação da Governança de Segurança Pública de 24 estados e do Distrito Federal, que teve como base o modelo de governança elaborado pelo Tribunal de Contas da União (TCU). Trata-se de modelo de avaliação de governança de segurança pública que levou em consideração as seguintes dimensões: estratégia; arranjos institucionais; tecnologia e conhecimento; resultados; gestão; pessoas e controles. Daí surgiu o iGovSeg que pode ser compreendido como um índice que visa demonstrar a capacidade e a habilidade que as organizações de segurança pública estaduais possuem para implementar as políticas de segurança pública.

Constata-se nesta fiscalização a busca por critérios, objetivos e comuns, que pudessem fornecer elementos para demonstrar o nível de governança do tema segurança pública. Esse índice proporciona uma visão nacional e traz relevantes informações sobre o aludido tema. Nesse sentido, a exemplo da auditoria em áreas protegidas, os resultados obtidos foram agrupados em quatro níveis de governança de segurança pública: i) aprimorado (iGovSeg igual ou superior a 75); (ii) intermediário (iGovSeg inferior a 75 e igual ou superior 50); (iii) inicial (iGovSeg inferior a 50 e igual ou superior 25); e (iv) insuficiente (iGovSeg inferior a 25).

Finalmente, cumpre sublinhar a utilização de sumario executivo e das peças técnicas (relatório técnico, voto do Ministro Relator e Acórdão do TCU) como instrumentos usados para dar notícia dos resultados alcançados. 


\subsubsection{Auditoria Coordenada em Atenção Básica à Saúde}

Os participantes dessa auditoria de âmbito nacional, realizada em 2014, foram: a) o Tribunal de Contas da União (TCU); b) os Tribunais de Contas dos Estados do Acre, do Amapá, do Amazonas, da Bahia, do Ceará, do Espírito Santo, de Goiás, do Mato Grosso, do Mato Grosso do Sul, de Minas Gerais, do Pará, da Paraíba, do Paraná, de Pernambuco, do Piauí, do Rio de Janeiro, do Rio Grande do Norte, do Rio Grande do Sul, de Rondônia, de Roraima, de Santa Catarina, de São Paulo e do Tocantins; c) o Tribunal de Contas do Distrito Federal; d) os Tribunais de Contas dos Municípios do Ceará, de Goiás e do Pará; e) os Tribunal de Contas do Município do Rio de Janeiro e do Município de São Paulo.

A referida auditoria coordenada teve como objeto comum a todos os Tribunais de Contas participantes a avaliação da qualidade da prestação dos serviços da atenção básica à saúde nas Unidades Básicas de Saúde (UBS). Buscou-se identificar os principais problemas que afetam a qualidade desses serviços, independentemente dos programas implementados em cada unidade avaliada.

Desse modo, o objetivo geral desta auditoria foi avaliar, de forma coordenada com os tribunais de contas estaduais e municipais, as ações governamentais que refletem na qualidade dos serviços oferecidos pelas UBS, com foco na resolutividade, no acesso, no atendimento e na estrutura disponibilizada, independentemente dos programas implementados.

Como resultado foram identificadas fragilidades no processo de levantamento das necessidades de saúde e de planejamento da atenção básica, bem como foi possível verificar precariedades no contrarreferenciamento de pacientes no âmbito do SUS, além de problemas na adoção de indicadores capazes de avaliar e monitorar os processos de trabalho.

Ao analisar o relatório da auditoria de atenção básica à Saúde, verifica-se que houve “dificuldades para consolidar e analisar tempestivamente as informações coletadas, tendo em vista a enorme quantidade de dados coletados pelos trinta tribunais de contas partícipes". (Retirado do relatório do Ministro Relator - Acórdão 1.714/2015, item 41).

Adicionalmente, nota-se a falta de indicadores comuns que forneçam uma visão crítica nacional a respeito da política pública de atenção básica à saúde. Por último, cabe ressaltar que, além do relatório técnico, do voto do Ministro Relator e do Acórdão do TCU, também se produziu um sumario executivo visando comunicar os resultados obtidos.

A seguir, apresenta-se uma tabela comparativa das auditorias coordenadas com o resumo das caraterísticas de cada trabalho realizado. 
Quadro 6-Comparativo entre as auditorias coordenadas

\begin{tabular}{|l|c|c|c|c|}
\hline Meorreferenciados & $\begin{array}{c}\text { Elaboração de } \\
\text { indicadores }\end{array}$ & $\begin{array}{c}\text { Dados } \\
\text { consolidados }\end{array}$ & $\begin{array}{c}\text { Comunicação } \\
\text { dos resultados }\end{array}$ \\
\hline $\begin{array}{l}\text { 1- Ensino } \\
\text { 2- Mudanças } \\
\text { climáticas }\end{array}$ & SIM & NÃO & $\begin{array}{c}\text { Sem um } \\
\text { panorama } \\
\text { regional }\end{array}$ & $\begin{array}{c}\text { Relatório e } \\
\text { Sumário } \\
\text { executivo }\end{array}$ \\
\hline 3- PAMA & SIM & NÃO & $\begin{array}{c}\text { Sem um } \\
\text { panorama } \\
\text { regional }\end{array}$ & $\begin{array}{c}\text { Relatório e } \\
\text { Sumário } \\
\text { executivo }\end{array}$ \\
\hline $\begin{array}{l}\text { 4- Recursos } \\
\text { Hídricos }\end{array}$ & NÃO & NÃO & $\begin{array}{c}\text { Sem um } \\
\text { panorama } \\
\text { regional }\end{array}$ & $\begin{array}{c}\text { Relatório e } \\
\text { Sumário } \\
\text { executivo }\end{array}$ \\
\hline $\begin{array}{l}\text { 5- Segurança } \\
\text { Pública }\end{array}$ & NÃO & NÃO & $\begin{array}{c}\text { Sem um } \\
\text { panorama } \\
\text { regional }\end{array}$ & $\begin{array}{c}\text { Relatório e } \\
\text { Sumário } \\
\text { executivo }\end{array}$ \\
\hline $\begin{array}{l}\text { Índice de } \\
\text { Governança de } \\
\text { Básica à } \\
\text { Saúde }\end{array}$ & & $\begin{array}{c}\text { Pegurança } \\
\text { nacional } \\
\text { Pública }\end{array}$ & $\begin{array}{c}\text { Sumáriório } \\
\text { executivo }\end{array}$ \\
\hline
\end{tabular}

Fonte: elaborado pelo Autor

Da tabela anterior, pode-se perceber que, no tocante à comunicação dos resultados, todos os trabalhos coordenados utilizaram, além do relatório, voto e acórdão, um sumário executivo para divulgar as principais constatações obtidas. Esse fato revela que o TCU tem buscado criar formas alternativas de comunicação com a produção de documentos mais sucintos de forma a atingir um número maior de interessados. Por outro lado, não foi identificada outra forma de divulgação, a exemplo da utilização de mapas georreferenciados na auditoria em áreas protegidas.

Noutro ponto, é preciso informar que, embora a auditoria do Ensino Médio e a auditoria do PAMA tenham elaborado mapas, esses trabalhos não utilizaram tais mecanismos para comunicar os resultados da auditoria. $\mathrm{Na}$ verdade, o uso de mapas se deu para explicitar determinado conjunto de dados, sem, no entanto, apresentar-se como uma ferramenta de avaliação, comunicação ou monitoramento.

Além disso, em geral as auditorias avaliadas, apesar de serem trabalhos coordenados, não apresentaram resultados de forma consolidada, tampouco as informações coletadas foram tratadas de forma a possibilitar a elaboração de relatórios sistêmicos que fornecessem panoramas regionais. Nessa direção, vale a pena mencionar ainda que, com exceção da 
auditoria em Segurança Pública, as demais fiscalizações não fizeram uso de indicadores, o que também prejudicou a confecção de uma visão crítica das Entidades de Fiscalização Superior sobre as políticas analisadas. Adicionalmente, em função do não estabelecimento de mecanismos eficazes para consolidação das informações produzidas por diversas EFS que geraram uma grande quantidade de dados, houve dificuldades para consolidar e analisar tempestivamente as informações coletadas, a exemplo do ocorrido na auditoria de atenção básica à Saúde. Isso porque os trabalhos coordenados acabam se transformando em um aglomerado de dados sem, no entanto, permitir a elaboração de um novo produto advindo da análise em conjunto de todos os dados consolidados. Essa situação acaba por ir de encontro aos objetivos dos trabalhos coordenados e, principalmente, dificultando os benefícios almejados com a realização de fiscalizações conjuntas.

Cumpre sublinhar que um dos ganhos esperados com a realização de trabalhos coordenados é a produção de diagnósticos amplos, sistêmicos e regionais. Nesse tipo de diagnóstico, onde são constatados problemas comuns, gargalos reiterados, boas práticas, fragilidades semelhantes entre atores, é possível alcançar um nível maior de conhecimento das causas dessas dificuldades e, assim, torna-se mais fácil a identificação de ações que favorecem ou dificultam o alcance pleno dos objetivos desenhados por determinada política. Além disso, ao envolver diferentes atores, facilita-se a proposição de ações conjuntas e medidas regionais e/ou globais, capazes de serem mais efetivas e dar resultados mais positivos do que a adoção de providências isoladas.

\subsection{Análise das entrevistas estruturadas}

Nesta terceira seção, são apresentadas e discutidas as respostas coletadas por meio do roteiro de entrevista realizado com servidores do Tribunal de Contas da União (TCU). O objetivo do instrumento utilizado era colher subsídios para identificar a influência do Indimapa no desempenho organizacional, em especial, quanto ao monitoramento, à padronização e à comunicação dos resultados da auditoria. Além disso, buscou-se analisar se o método criado pode ser considerado uma inovação de serviços no âmbito do TCU, utilizando os quatro tipos de inovação: produto, comunicação, organizacional ou processo.

Para organizar os dados obtidos nas entrevistas realizadas, foram estabelecidos temas que serão analisados de forma individual e com base nas respostas dos seis entrevistados.

\subsubsection{Inovação}

Como primeiro item do roteiro de entrevista e como forma de iniciar a abordagem do 
tema da presente pesquisa, a primeira questão buscou avaliar a importância da inovação para o controle externo e sua contribuição para a melhoria dessa atividade. Das respostas obtidas, constata-se de um modo geral a importância de implementação de práticas inovadoras como forma de aperfeiçoar a ação do TCU. Nessa linha, o entrevistado D afirmou que:

Inovação é fundamental para a vida das pessoas e das instituições. Organizações que não inovam morrem. Então, não se pode ter medo de inovar. Mesmo uma organização secular como tribunal tem que inovar, procurar novas formas, aprimorar. A sociedade cobra cada vez mais e, com o fortalecimento da democracia, a gente está sendo cada vez mais cobrado para dar melhores resultados. Assim, aquele modelo anterior, cartorial, burocrático, acho que hoje ninguém quer mais isso. Então você tem que inovar.

No mesmo sentido, a resposta do entrevistado B enfatiza a relação entre inovação e aperfeiçoamento do desempenho quando diz que "o conceito de inovação deve estar associado à questão da melhoria". Por sua vez, o entrevistado A destacou a necessidade de utilizar novas abordagens como instrumento para despertar a atenção de diferentes atores.

As gerações atuais estão acostumadas em lidar com linguagens criativas, visuais que geram interesse e a curiosidade, aspectos essenciais da inovação a quem o controle externo deve se orientar. As pessoas têm que estar interessadas no nosso trabalho. Além disso, o processo de inovação tem impacto positivo no desempenho do controle externo.

Já o entrevistado $\mathrm{B}$ chamou a atenção para o risco da não incorporação de práticas inovadoras no TCU, pois em seu entendimento, “o que ocorre atualmente é que existem muitas ideias pessoais que são importantes, mas não têm sustentabilidade, ou seja, acabam se perdendo, pois estão personificadas".

Por sua vez, o entrevistado $\mathrm{F}$ destacou que uma forma de inovação poderia ser uma maior interação com o Congresso que passasse a ser mais fiscalizador, por meio de uma cobrança dos resultados do gestor, da política pública, nas comissões parlamentares.

Percebe-se, pois, uma variedade nas respostas quanto ao processo de inovação no controle externo, o que indica a necessidade de se buscar uma visão mais homogênea e compartilhada a respeito da política de inovação no TCU. Para superar essa fragmentação, o TCU criou, em fevereiro de 2015, o Centro de Pesquisa e Inovação (CePI) com o objetivo de fomentar a pesquisa aplicada no tribunal e coordenar o coLAB-i, primeiro laboratório de inovação em governo em um órgão de controle.

Desde sua criação, o coLAB-i oferece suporte às unidades do tribunal no desenvolvimento de projetos inovadores, com vistas a garantir a gestão do conhecimento no 
que se refere a soluções desenvolvidas, além de coordenar de promover ações de capacitação e eventos sobre assuntos técnicos. Vale a pena mencionar que os laboratórios de inovação estão sendo criados no mundo todo com diferentes objetivos, mas todos eles buscam produzir melhores serviços, o que ocorrerá com a abertura dos órgãos públicos à inovação, oportunidade em que se poderá tratar problemas complexos com foco no cidadão.

Mais recentemente foi lançado o Portal inovaTCU que é um espaço virtual de compartilhamento de conhecimentos e cujo objetivo é estimular a publicação de informações de todo e qualquer projeto de inovação no tribunal, além de notícias, eventos e documentos técnicos. Assim, espera-se, com a adoção dessas medidas, que uma cultura de fomento à inovação no controle externo seja efetivamente implementada no TCU e possa contribuir para a sustentabilidade das práticas inovadoras.

\subsubsection{Mapas georreferenciados}

Em relação ao item dois do roteiro de entrevista, que tratava da frequência da utilização de mapas georreferenciados em auditorias do TCU e das vantagens do georreferenciamento, os entrevistados declararam que o uso desses mecanismos é raro e ainda não está disseminado no tribunal, tendo sido mencionadas apenas duas auditorias que lançaram mão desse tipo de ferramenta, conforme pode ser observado nas respostas colhidas:

Não é muito frequente a utilização de mapas georreferenciados nas auditorias. (Entrevistado B)

Ainda não é frequente, mas já ocorreu em, pelo menos, duas auditorias. (Entrevistado D)

De fato, são poucos os casos de trabalhos do tribunal que usam essa tecnologia. (Entrevistado E)

Eu não lembro de nenhuma experiência de usar georreferenciamento, já teve apenas como informação descritiva. (Entrevistado F)

Não é comum, e até raro. Ainda mais algo tão elaborado que teve que ser customizado para atender uma demanda, uma pergunta de auditoria.

Não me recordo de algo tão customizado como esse. Já houve alguns trabalhos, no entanto, não era tão sofisticado. Eu vi muitos poucos trabalhos utilizando mapas dessa maneira. Em muitas das ações de controle, acho que cabe a utilização do georreferenciamento. Se você quer analisar política pública dentro de uma área, de um estado, de uma região, acho que o georreferenciamento pode ajudar. (Entrevistado C)

Em que pese a utilização isolada nesses dois trabalhos, importante observação fez o entrevistado A quando afirmou: 
O tribunal já tem alguns trabalhos que utilizaram a informação georreferenciada, porém não de forma sistematizada nem em grande volume. Assim, temos casos isolados e não para obter uma visão sistêmica, como por exemplo, em obras e outros trabalhos relativos a políticas públicas.

Não tenho visto nenhum trabalho que tenha utilizado sistematicamente essa tecnologia para construção e tabulação de dados, e depois inferência e trazer evidências.

O trabalho de áreas protegidas foi o primeiro que eu vi, pode ser que tenha, nunca vi, eu estou aqui há 18 anos, um trabalho que tenha gerado mapas com informação georreferenciada para facilitar a comunicação. (Entrevistado A)

Tão importante quanto utilizar esses mecanismos é identificar as vantagens do seu uso para as atividades do controle externo. Nesse sentido, o entrevistado B salientou que "uma vantagem é, por meio do cruzamento de dados, poder produzir relatórios gerenciais. Além disso, fica mais fácil de se comunicar com o Congresso Nacional”. Na mesma direção, o entrevistado D enfatizou outro benefício:

Uma grande vantagem é a facilidade de compreensão. Portanto, é muito importante porque você consegue entender rapidamente o resultado sem necessariamente ler páginas e páginas dos relatórios técnicos, os quais muitas vezes são extensos. E hoje as pessoas têm muito pouco tempo para ler uma vez que são inundadas com um volume grande de informações.

Então, quando você passa a informação, por meio de um mapa, um gráfico, é muito mais rápido. A chance de você conseguir passar a sua mensagem, resultado do seu trabalho, é muito maior. (Entrevistado D)

Aprofundando um pouco mais, o entrevistado $\mathrm{E}$ traz a importância do georreferenciamento nos dias de hoje.

Hoje, falar em georreferenciamento é a mesma coisa que falar em relatório sem usar o Word ou Excel. São esses elementos básicos de tecnologia que a gente tem que incorporar no nosso trabalho. Da experiência que tenho no tribunal, o georreferenciamento te permite trazer as informações de uma forma que sem ele, é como o Excel, uma planilha você é capaz de expressar elementos contábeis, financeiros com gráficos e tabelas, e fazer manipulações dessas informações que você consegue mostrar de maneira inteligível e até mesmo simplificada. E a mesma coisa acontece com o georreferenciamento. Você consegue mostrar mapas, figuras e realizar uma série de ilustrações que te conduzem ao desenvolvimento de um raciocínio que, sem essas ferramentas, fica totalmente ineficiente e pouco efetiva a tua ação. Para mim, o georreferenciamento como gráficos, como planilhas, são coisas do cotidiano. A gente tem que saber lidar com isso. (Entrevistado E)

Já o entrevistado F salienta a relevância e aplicabilidade do georreferenciamento em auditorias que avaliem políticas distribuídas por todo território nacional.

O georreferenciamento é importante ainda mais em trabalhos como esse em que você está tratando de localização espacial, espaços geográficos. É fundamental ainda mais em um país como o Brasil, onde você não dispõe de dados confiáveis a respeito de propriedade, localização de terras, ocupação de território. Portanto, é uma ferramenta que chegou no momento certo ao 
tribunal e deve ser incorporada. (Entrevistado F)

Portanto, verifica-se que a utilização de mapas georreferenciados, além de ser uma prática nova no âmbito do TCU, é, na visão dos entrevistados, uma ferramenta com potencial de contribuir para a melhoria das atividades do controle externo. Vale destacar que, em 2015, deu-se início a um projeto para uso de geotecnologias como uma nova ferramenta para o controle externo, o que sinaliza que a utilização de georreferenciamento começa a ser incorporada nas unidades do TCU.

\subsubsection{Monitoramento}

A pergunta três questionava sobre a contribuição do uso de mapas georreferenciados ou instrumentos de georreferenciamento para a atividade de monitoramento do TCU. O entrevistado A chamou a atenção para o fato de que "o Indimapa é uma excelente ferramenta de comunicação, além de permitir um monitoramento e avaliação constantes porque existem os índices". Na mesma direção, o entrevistado C disse que:

Não tenho dúvida que sim. Agora a questão é avaliar o grau de confiabilidade das informações que são base para extração dos dados que vão compor o georreferenciamento. Se essa confiabilidade está sendo assegurada, a resposta é sim. (Entrevistado C)

Em complementação, o entrevistado D afirmou que:

Não tenho dúvida. Pela facilidade de manipulação de informações, uma vez que você monta um mapa, atualizar isso fica muito mais fácil.

Uma vez que o trabalho tenha sido feito e considerado esse tipo de instrumento, você pode com certeza repetir, utilizando os mesmos mecanismos e fazer o monitoramento desses dados de uma forma muito mais dinâmica. O Tribunal deve se direcionar para incorporar esses instrumentos. (Entrevistado D)

Compartilhando do mesmo entendimento, o entrevistado E informou que:

Claro. É igual a uma tabela que você usou. Você vai mostrar no ano 1, depois no ano 5 e você vai poder comparar. Do mesmo jeito que os mapas permitem fazer uma comparação com diferentes unidades de conservação, com dois mapas você consegue visualizar como o conjunto de unidades estava em um determinado instante de tempo e como ele está hoje. Então, a evolução fica muito clara e tem um apelo visual muito forte. (Entrevistado E)

De forma complementar, o entrevistado B destacou que "o ponto alto é a comunicação, passar a mensagem". Ainda mais enfático, o entrevistado F asseverou que:

Ele melhora o monitoramento, já que tem a possibilidade de torná-lo mais 
efetivo, a partir do instante que, com dados georreferenciados, você pode acompanhar alterações ao longo do tempo, como no caso de terras. Além disso, tem a importância de uma cobrança, de uma atuação do governo em um estágio mais avançado. Uma vez que o tribunal avalia e coloca as informações de forma georreferenciadas, o governo tem que se preparar e passar atuar com essa lógica.

Com certeza, torna mais efetivo. (Entrevistado F)

As respostas apresentadas denotam que, no entendimento dos entrevistados, a utilização de instrumentos de georreferenciamento, como no caso da auditoria em áreas protegidas, contribui para a atividade de monitoramento do TCU, especialmente pelo fato de possibilitar o acompanhamento ao longo do tempo das alterações ocorridas, o que permitirá fazer comparações longitudinais, por exemplo, entre as diferentes unidades de conservação, tornando, consequentemente, mais efetivo o monitoramento.

\subsubsection{Comunicação}

O item quatro buscava compreender se a comunicação dos resultados da auditoria por meio de mapas geográficos era mais acessível para a sociedade. Todos os entrevistados, com exceção do entrevistado B, foram unanimes em afirmar que o uso de mapas georreferenciados tornava mais inteligível e compreensível os resultados da avaliação do tribunal.

Outro ponto é a leitura de organogramas e fluxogramas e a forma mais adequada de comunicar. A partir daí a criação de indicadores para monitorar e avaliar, a fim de saber se as políticas estão realmente alcançando os objetivos para os quais foram criadas.

Acredito que sim, pois a linguagem escrita limita um pouco mais. Não substitui a linguagem a escrita, mas proporciona uma compreensão mais rápida e qualificada, pois ao olhar o mapa, é possível ver mais representatividade, já que é uma linguagem visual e a linguagem visual é mais acessível. Acho que se o mapa for construído de uma forma que gera informação e ela está respaldada em critérios, o resultado é melhor compreendido.

O mapa facilita a compreensão do leigo, independentemente do assunto. Assim, o mapa acaba despertando o interesse da população para compreender melhor as políticas públicas.

O mapa consegue amplificar a mensagem que se quer passar, pois você já fez a interpretação das informações, ele já contém a informação tratada para o interlocutor. (Entrevistado A)

Com a mesma visão, o entrevistado B mencionou que:

Você dispõe de outros elementos para se comunicar com diferentes atores, e isso dá início ao processo de cobrança por melhores resultados, de responsabilização, de accountability, de transparência etc.

Você não precisa de um relatório, com um infográfico é possível ser compreendido e transmitir uma mensagem. 
Corroborando o entendimento dos demais, o entrevistado D afirmou que:

É muito mais acessível, isso nem se compara. Um exemplo é o trabalho de unidades de conservação. A facilidade de você explicar com a utilização do mapa. Pela facilidade de compreensão do mapa, todos os países, que não tinham participado da auditoria, ficaram extremamente interessados para ver como estava a situação ambiental de seu país em comparação com os demais.

E eu credito isso em boa medida a utilização de ferramentas gráficas e de georreferenciamento.

Até por uma questão que todos gostam de se ver, né? Assim, você bate o olho: "Eu já fui àquela unidade. O que está acontecendo lá?". Se fosse uma tabela com várias páginas, até você se localizar, o tempo é muito maior e até desmotivaria a fazer. É muito interessante.

A produção de mapas visou obter formas mais efetivas de comunicação, de passar a mensagem.

A partir do momento que você comunica melhor seu trabalho, as pessoas começam a entender melhor a instituição e os resultados do trabalho. Possibilita compreender melhor como está a eficiência das políticas públicas. Acho, portanto, que fortalece a imagem da instituição através dos resultados do trabalho. Além do maior conhecimento do escopo de atuação do tribunal.

Por outro lado, o entrevistado C fez algumas considerações.

Se é a comunicação com o congresso, eu acho que sim. Porque eventualmente você estará falando com os congressistas e eles podem não ler, mas os assessores deles vão ler, os consultores vão ler e são pessoas que têm cabedal para entender esse mapa. Porque esse é um tipo de comunicação mais sofisticada.

Portanto, depende da parcela da sociedade com a qual você está querendo comunicar. Para o pessoal das ONGs, do Congresso, da sociedade acadêmica, para imprensa mais especializada também.

De forma similar, o entrevistado E alertou para o seguinte ponto:

Sim, claro. No entanto, temos que entender que os mapas são o produto final, estão lá na ponta. Isso sozinho não basta. O importante dessa auditoria foi que tivemos uma metodologia na qual buscamos treinar as pessoas na aplicação da metodologia e aplicar critérios que são coerentes, concretos e replicáveis.

Não só foi o uso da ferramenta de georreferenciamento para comunicar. Se você pegar, por exemplo, aqueles gráficos em forma de teia, isso não é georreferenciamento, mas foi uma das formas que você consegue visualizar uma unidade. Você consegue comparar um gráfico de uma unidade com outra e verificar as diferentes dimensões e tem um apelo visual de mostrar o que está bom e o que está ruim. E depois, você associa isso com cores que são levadas aos mapas. Isso foi importante, mas só foi possível porque tínhamos uma metodologia de trabalho por trás disso.

Seguindo o mesmo raciocínio, o entrevistado $\mathrm{F}$ afirmou:

Sim, porque entra na parte de recursos gráficos e facilita porque, ainda mais da forma que foi colocado na auditoria, ele traz muita informação que é mais fácil de aprender do que da forma que você coloca em um texto. Acho que a 
importância dele é essa, porque para o grande público, para aquelas pessoas que não especializadas no tema, então o mapa consegue traduzir muita informação de maneira direta. Então, isso com certeza traz mais interesse, atrai mais participação. Isso é uma ferramenta que, quando cabível, é sempre bom e importante por conta disso.

Um dos pontos mais abordados pelos entrevistados estava relacionado à comunicação de resultados por meio da utilização de mapas georreferenciados. Pelas respostas dadas, é possível identificar que o uso de linguagens gráficas otimiza o processo de divulgação, uma vez que facilita a compreensão da mensagem que se quer transmitir, assim como desperta a atenção de leitores. Além disso, mostra-se como uma forma mais rápida de comunicação, já que, em apenas uma visualização, torna-se possível compreender o resultado de uma auditoria sem, necessariamente, obrigar a ler o relatório completo.

Outro ponto que merece destaque, entre os benefícios decorrentes da utilização de mapas de georreferenciados, é a inteligibilidade da mensagem a ser passada tendo em vista que, em função da classificação e legenda utilizadas na auditoria em áreas protegidas (faixas verde, amarelo e vermelho representando respectivamente alto, médio e baixo grau de gestão), viabiliza-se a compreensão pelos cidadãos que não são especialistas na temática ambiental, por exemplo.

Esse fato acaba sendo essencial para o controle de políticas pública, pois permite aos diferentes segmentos da sociedade tomar conhecimento da ação governamental e, posteriormente, cobrar dos agentes públicos a adoção de medidas para melhoria da máquina pública. Esse processo contribui para o aumento da transparência na administração pública, melhoria da responsabilização administrativa por desempenho, e fomenta o controle social (accountability), fortalecendo a democracia representativa.

\subsubsection{Padronização/consolidação}

Este item tinha por objetivo identificar se o Indimapa contribuía para a padronização dos resultados de trabalhos coordenados, e se o fato de se utilizar índices e indicadores ajudava na consolidação dos resultados.

As respostas, em geral, foram no sentido de que, para a realização de trabalhos coordenados, é imprescindível que se defina parâmetros e critérios comuns que propiciam, ao final do trabalho, a consolidação das informações de forma a permitir a elaboração de diagnósticos sistêmicos, a exemplo do que ocorreu na auditoria de áreas protegidas. Outro ponto destacado é a necessidade de instrumentos de consolidação para possibilitar realizar comparações, e efetuar uma homogeneização das informações. 
Corroborando esse entendimento, o entrevistado A sublinhou que:

A coleta anterior de dados e sua análise contribuem para a profissionalização do controle externo. Assim, consegue-se criar instrumentos padronizados que tabulam dados permitindo ainda o cruzamento de informações como, por exemplo, o IDH de uma região com a gestão de áreas protegidas. Ou seja, a sobreposição de dados facilita a atuação do controle externo e permite, por meio da inferência, a antecipação sobre alguns eventos.

O Indimapa é resultado de uma metodologia relacionada à padronização.

É uma padronização seletiva dos aspectos mais importantes. Em seguida, você faz um alinhamento com todos os atores envolvidos da auditoria, seja uma equipe pequena, ou que tenha a participação de outros órgãos de controle nacionais ou internacionais. Depois de consolidar todas as informações, eu tenho muito mais condições e conhecimento de causa e autoridade para propor medidas globais, ações conjuntas que podem dar mais resultados pois envolvem mais atores, eu tenho mais capacidade de mobilização. Consigo identificar boas práticas ou também problemas crônicos e repetidos. Além disso, é possível identificar ações que contribuem ou atrapalham o pleno alcance dos objetivos pretendidos por determinada política. (Entrevistado A)

Nessa vertente, o entrevistado D salientou que:

O grande desafio de um trabalho coordenado é obter uma uniformização de linguagem, de metodologias. Então, à medida em que você tem algo que facilita essa compatibilização, como por exemplo o indicador, apesar de não ser o único, isso tudo facilita a obter um trabalho homogêneo com diversos atores. Acho que a utilização de índices, indicadores e mapas facilita a participação e o engajamento de todos nesse processo coordenado. (Entrevistado D)

Trazendo informações adicionais, o entrevistado E complementou:

Se você delimitar um escopo e todo mundo seguir esse escopo usando uma mesma metodologia, você consegue chegar numa visão comparada. Quando a coordenação é malfeita ou não é suficientemente precedida de todos os elementos de convencimento, você vai ter uma pessoa querendo falar do elemento A e outra querendo falar do elemento B. Além do produto final que é o relatório final com maior qualidade, você a construção de capacidades das equipes que participaram.

Quando você tem várias equipes bem treinadas, você consegue ver o que é um relatório bem feito em comparação aos relatórios das equipes que não foram treinadas.

Ao mesmo que ela te permite comparar diferentes objetos avaliados, ela também te permite comparar relatório da instituição A com o da instituição B. Essa é uma ótima medida de desempenho. Portanto, as auditorias coordenadas te permitem treinar as equipes no início do processo e no final aferir se o treinamento foi adequado ou não. Essa é a grande a inovação que a auditoria traz. (Entrevistado E)

Por último, a resposta do entrevistado F ressalta que: 
O grande mérito do trabalho de áreas protegidas nesse aspecto foi que ele identificou parâmetros e ferramentas que seriam universais. Ou seja, ele partiu de certas informações que vem de tratado, usando isso como critério que pode ser traduzido para todos os atores envolvidos. Aproveitou de ferramentas de organismos que já tinham quebrado a cabeça com isso, como WWF, Banco Mundial. Aproveitou isso, não tentou inventar a roda, conseguiu obter um objetivo de auditoria que fosse possível de ser comum a todos. Isso foi muito importante na parte de desenho e planejamento do trabalho porque permitiu identificar aquilo que era comum, possível de ser passado, transladado para outros países. Isso tudo levou a possibilidade de comparar, de fazer algum tipo de homogeneização das informações.

Acho que isso foi uma das características importantes desse trabalho. (Entrevistado F)

Vê-se que a utilização de indicadores e índices, tal qual na auditoria em áreas protegidas, mostra-se útil na medida em que facilita obter uma uniformização de linguagem e uma definição mais clara com o estabelecimento de critérios objetivos de avaliação, os quais permitem realizar comparações entre situações analisadas, além de trazer mais homogeneidade aos resultados dos trabalhos que envolvam diferentes atores.

Os dados colhidos nas entrevistas indicam, ainda, a preocupação dos entrevistados no sentido de que sejam utilizados instrumentos padronizados, replicáveis e comparáveis durante os trabalhos coordenados, de modo a fornecer elementos essenciais à produção de relatórios regionais, os quais possuem maior valor em função do diagnóstico em maior escala e, consequentemente, da visibilidade que oferecem e do interesse que despertam em diferentes atores sejam eles: agências governamentais, instituições privadas, organizações nacionais e organismos internacionais.

\subsubsection{Gráfico de radar}

A questão cinco indagava quais eram as principais características do Gráfico de Radar/Aranha, além da frequência de utilização desse tipo de representação gráfica. De início, vale dizer que os entrevistados, à exceção do entrevistado B, mencionaram que, apesar de conhecerem esse tipo de gráfico, nunca viram a utilização de tal imagem em auditorias do TCU.

Já em relação às características inerentes a esse tipo de representação gráfica, as respostas apontaram a facilidade de identificação de pontos fortes e fracos, de forma simultânea, ou seja, a incorporação de diferentes elementos em apenas uma figura, o que proporcionaria uma análise multidimensional.

Além disso, em função da representação da imagem utilizada, não é necessário ler um 
texto completo para interpretar os dados e chegar a determinadas conclusões como o diagnóstico dos aspectos mais frágeis e que requerem uma intervenção prioritária. Adicionalmente, pela própria figura do gráfico, há um interesse e curiosidade para decifrá-lo, como se pode observar das respostas abaixo.

É uma linguagem gráfica ilustrativa que tem o poder de chamar a atenção das pessoas para informação já que gera curiosidade. Como ele é visual, permite-se comparar um com o outro e identificar pontos fortes e fracos e a classificação dos indicadores. É possível combinar indicadores e duas questões relacionadas estão ruins e são as mais importantes. Se você me dá o gráfico de radar, eu não preciso ler um texto para chegar a essas conclusões. (Entrevistado A)

Não tenho visto muitos trabalhos que utilizaram esse tipo de representação gráfica, ainda mais numa escala como foi utilizado no trabalho das áreas protegidas. (Entrevistado B)

Não vi nenhum trabalho utilizando esse tipo de trabalho. Se houve, foi muito raro. Acho que ele pode ajudar. Para entender as áreas mais desenvolvidas ou menos implementadas. (Entrevistado C)

Eu já conhecia esse gráfico, mas não lembro em auditoria. Seguramente posso afirmar que na magnitude que foi utilizado na auditoria de áreas protegidas, eu nunca vi.

Colocar um mapa com gráficos para cada uma das áreas, eu nunca tinha visto, foi a primeira vez. Acho que esse tipo de representação gráfica facilita muito a compreensão.

Um dos pontos altos dessa auditoria foi a simplicidade de comunicação, em função das cores, do preenchimento. Isso facilitou demais pois rapidamente é possível identificar pontos fortes e fracos. (Entrevistado D)

Não sei dizer de cabeça, mas certamente já deve ter tido trabalhos no tribunal que utilizaram esse gráfico.

O gráfico de radar serve para ilustrar uma situação que você quer demonstrar, mapear várias variáveis ao mesmo tempo. Mas o mais importante não é o gráfico em sim. O grande elemento é que a gente pensou em várias formas de visualização e de comunicação.

Então é a combinação desse gráfico de radar com o mapa, classificado em cores, com índices, são esses diferentes aspectos que te permitem construir uma visão.

O importante é o conjunto da obra, a coerência do índice que foi desenvolvido em conjunto com o uso dessas ferramentas de visualização. Isso vai reforçando e permitindo escolher as ferramentas que são mais efetivas do ponto de vista da comunicação dos resultados. Mas a comunicação dos resultados é apenas um elemento que está no final do processo de auditoria. (Entrevistado E)

Eu não lembro de ter visto esse tipo de representação gráfica nos trabalhos do tribunal. Com certeza, posso afirmar que não é frequente a utilização desse gráfico. O grande mérito desse gráfico é justamente incorporar diversos aspectos em um único elemento visual. Ele te dá um monte de 
informação sob diversos aspectos em uma só figura, permitindo uma análise multidimensional identificando pontos fortes e fracos. (Entrevistado F)

Vê-se, portanto, que o gráfico de radar, tal como foi utilizado na auditoria em áreas protegidas, aparece como uma forma alternativa de comunicação já que desperta a curiosidade dos leitores, além de se apresentar como uma ferramenta que propicia análises multidimensionais e comparações entre diferentes elementos. Esse fato implica a melhora da atuação do TCU que passa a ser mais eficiente, uma vez que, ao identificar áreas prioritárias a serem fiscalizadas, otimiza-se o tempo de visitas a campo e diminui a subjetividade na escolha dos locais vistoriados.

\subsubsection{Quadro de normativos}

O item pretendia avaliar as principais características do Quadro de Normativos e se esse tipo de fluxograma era utilizado no TCU para fornecer uma visão do arcabouço jurídico. De forma unânime, os entrevistados, ao comentarem a originalidade do produto desenvolvido durante a auditoria de áreas protegidas, destacaram o ineditismo desse tipo de fluxograma para retratar o sistema jurídico de determinado tema. Também ressaltaram a facilidade de identificação de conflitos, lacunas e sobreposições normativas, bem como a hierarquização entre as normas.

Ao fazer esse produto, você consegue enxergar outras questões como conflitos de normas, lacunas, sobreposições, duplicidade e falta de integração do sistema. Vê a complexidade do sistema. Além de enxergar a quantidade e a hierarquia dos normativos.

A imprensa consegue entender, o parlamento. (Entrevistado A)

O entrevistado B observou a inovação desse produto.

Nunca tinha visto um produto como esse sendo utilizado para mapear o campo normativo de determinada área. (Entrevistado B)

Já o entrevistado C destacou que:

Facilita também uma consulta ou um consumo interno da própria secretaria. Às vezes é possível ver sobreposição de atividades. Esse tipo de representação obriga um raciocínio lógico sobre fluxo de trabalho. Ele te obriga a uma reflexão.

Acho que seu uso deveria ser obrigatório em alguns casos. (Entrevistado C)

Indo além, o entrevistado D enfatizou:

Nunca tinha visto um produto desse nas auditorias. Ele facilita bastante em função da hierarquização que ele possui. Seria o ponto alto desse quadro. A vantagem é você poder partir do maior para o menor de uma forma muito simples. Esse produto eu realmente não conhecia e permite visualizar a complexidade do sistema e lacunas normativas. (Entrevistado D) 
De forma similar, o entrevistado E informou que:

Eu nunca vi esse tipo de visualização para fins normativos. Eu acho que ficou muito interessante isso porque é uma das formas de conseguir apresentar de uma maneira bem visual e expressar um conhecimento que ele é necessário para as pessoas trabalharem e fazerem um julgamento objetivo baseado em critérios.

Especificamente em relação a normativos, eu não conheço e acho que foi uma inovação, fazendo uma analogia com outros produtos que existiam para outras áreas. Acho que foi uma adaptação interessante e que é uma boa ideia. Ela te permite ter uma visão sistêmica da situação normativa. (Entrevistado E)

Por fim, o entrevistado $\mathrm{F}$ afirmou:

Acho importante para organizar a informação, não somente para os auditores, como também para todos os usuários do trabalho, uma vez que a parte normativa é base de toda política. Ele também serve de base para identificar lacunas e sobreposições. Também facilita a hierarquização normativa. (Entrevistado F)

Nota-se, portanto, que a elaboração do Quadro de Normativos confere maior compreensão a respeito do arcabouço jurídico analisado, por meio da sistematização e hierarquização da informação legal e infralegal, caracterizando-se, ainda, como um documento para consultas futuras. Por fim, deve-se mencionar que o modelo do Quadro de Normativos pode ser utilizado para outros temas e órgãos e entidades jurisdicionados ao Tribunal de Contas da União.

\subsubsection{Replicabilidade do Indimapa}

Ao serem questionados a respeito da possibilidade de o Indimapa ser replicado em outras áreas do TCU, os entrevistados apontaram o mesmo caminho.

Eu acredito que sim. Pois isso é uma expertise. Foi chamado de Indimapa mas poderia ser chamado de qualquer outra coisa. Mas se a metodologia é aplicada sistematicamente e criteriosamente, vai gerar um produto importante para compreensão, comunicação, auxilia no processo decisório, ajuda no encaminhamento do próprio tribunal, o monitoramento, a avaliação. Acho que a forma de aplicar pode ser a mesma gerando produtos diferentes. Às vezes, para determinado trabalho, apenas o gráfico de radar já pode ser suficiente, já comunica bem. (Entrevistado A)

O entrevistado B respondeu que é possível "desde que se tenha orientação sobre como fazer e estejam disponíveis as ferramentas necessárias relativas à tecnologia da informação". Já o entrevistado $\mathrm{C}$ informou que: 
Não tenho dúvidas. Em alguns casos, deve. Quando se fala de políticas que são nacionais, regionais, se você dispõe de dados, eu não tenho dúvidas de que uma representação, não precisa ser exatamente essa, mas inspirada nessa, deve ser usada pois ela comunica rapidamente o estado da arte. (Entrevistado C)

Por sua vez, o entrevistado D destacou que "sem dúvida já que o campo de utilização é vastíssimo". Compartilhando da mesma visão, o entrevistado E salientou que:

Claro, não só ela pode como ela está sendo. Como você trata de um mesmo tema e tem o mesmo escopo, ela te permite fazer essas comparações e aferições em termos de desenvolvimento profissional. Portanto, além de trazer elementos de comparação de resultados dos objetos avaliados, ela te permite fazer comparações do desempenho das equipes. (Entrevistado D)

De modo complementar, o entrevistado F ressaltou que:

Acho que sim. É claro que por lidar com coisas muito diversificadas, o tribunal deve avaliar a viabilidade. Creio que certos aspectos são facilmente incorporados, como a árvore de problemas que já foi replicada no trabalho de crise hídrica. É uma ferramenta que ajuda a organizar e pode ser replicável. A questão dos indicadores é sempre importante.

Essa auditoria foi muito feliz ao pegar indicadores que fizessem sentido e permitissem dar uma ideia efetiva da situação analisada.

Já a parte de georreferenciamento deve ser avaliada caso a caso.

A ideia de estabelecer um ranking é importante porque dá uma comparação direta e isso para o gestor é altamente motivacional, pois para quem não está tão bem classificado fica incomodado e quer melhorar enquanto que quem está bem classificado fica estimulado a manter. Isso deve servir como estímulo para um aperfeiçoamento contínuo. (Entrevistado F)

O entrevistado D trouxe um ponto fundamental: a necessidade de formalização do Indimapa por meio de sua institucionalização no âmbito do TCU, pois, caso contrário, em sua percepção, há um risco de se perder o conhecimento e abordagem desenvolvidos durante a auditoria em áreas protegidas.

Eu acho que isso tudo que foi feito na auditoria de áreas protegidas precisava que a nossa área de metodologia, atualmente Semec, ex-Seaud, estar próxima participando disso, de modo a permitir a difusão desse conhecimento.

Portanto, um dos grandes desafios é ter uma base para essa inovação para evitar que as coisas fiquem só em espasmos. Acho que precisamos, cada vez mais, fortalecer esse papel da unidade responsável pelas metodologias. Como induzir isso aqui dentro? Esse é um grande desafio.

Uma outra questão é a institucionalização de forma a não deixar restrito a determinada pessoa, ou seja, a gestão do conhecimento. (Entrevistado D)

Das respostas coletadas, ficou evidente que, na visão dos entrevistados, o método ou abordagem de avaliação, no caso em questão denominado de Indimapa, pode ser aplicado pelas diferentes áreas técnicas do TCU quando da realização de futuras fiscalizações, em 
especial para os trabalhos conjuntos, a exemplo das auditorias coordenadas. Em função dos benefícios advindos do Indimapa, faz-se necessário que este método seja difundido e institucionalizado no tribunal.

\subsubsection{Classificação da inovação de serviços}

Os últimos itens do roteiro de entrevista buscavam avaliar se o Indimapa poderia ser considerado uma inovação no TCU e, em caso afirmativo, em qual ou quais tipos de classificação essa ferramenta poderia ser enquadrada, levando em consideração as definições do Manual de Copenhagen (MEPIN, 2011). A tabela seguir traz os resultados consolidados.

Quadro 7 - Consolidação das respostas dos entrevistados:

Indimapa segundo classificação de inovação

\begin{tabular}{|l|c|c|c|c|c|}
\hline & $\begin{array}{c}\text { Inovação no } \\
\text { TCU }\end{array}$ & $\begin{array}{c}\text { Inovação de } \\
\text { produto }\end{array}$ & $\begin{array}{c}\text { Inovação em } \\
\text { comunicação }\end{array}$ & $\begin{array}{c}\text { Inovação } \\
\text { organizacional }\end{array}$ & $\begin{array}{c}\text { Inovação de } \\
\text { processo }\end{array}$ \\
\hline Entrevistado A & Sim & Sim & Sim & Não & Não \\
\hline Entrevistado B & Sim & Não & Sim & Não & Não \\
\hline Entrevistado C & Sim & Sim & Sim & Sim & Sim \\
\hline Entrevistado D & Sim & Não & Sim & Não & Não \\
\hline Entrevistado E & Sim & Sim & Sim & Sim & Sim \\
\hline Entrevistado F & Sim & Sim & Sim & Não & Sim \\
\hline TOTAL & $100 \%$ & $66 \%$ & $100 \%$ & $33 \%$ & $50 \%$ \\
\hline
\end{tabular}

Fonte: elaborado pelo Autor

Do quadro 4 é possível verificar que houve uma unanimidade na visão dos entrevistados quanto à caracterização do Indimapa como uma inovação no TCU. Também houve consenso entre eles a respeito da classificação do Indimapa como uma inovação em comunicação. Já em relação ao enquadramento do aludido instrumento de avaliação como uma inovação de produto no TCU, quatro dos seis, ou seja, 66\% dos entrevistados chegaram à essa mesma conclusão. Quanto à inovação em processo, metade dos entrevistados afirmou que o Indimapa poderia ser encaixado nessa classificação. Por outro lado, apenas dois entrevistados $(33 \%)$ entenderam que a referida ferramenta poderia ser enquadrada como uma inovação organizacional.

Ao analisar os dados, ratifica-se o entendimento de que a ferramenta Indimapa deve ser considerada como uma inovação de serviços no TCU, uma vez que ela atende ao conceito proposto por Koch e Hauknes (2005) no qual inovação é a implementação ou desempenho de uma nova forma específica ou repertório de ação social, implementada deliberadamente por uma entidade no contexto dos objetivos e funcionalidades de suas atividades. Na mesma linha, a ferramenta também cumpre os requisitos estabelecidos pelo Manual de Copenhagen (MEPIN, 2011), o qual define inovação como a implementação de uma mudança significativa na forma como a organização opera ou nos produtos que fornece, implicando alterações novas ou significativas para serviços e bens, processos operacionais, métodos organizacionais, ou a 
forma como a organização se comunica com os usuários.

Além disso, deve ser classificada como uma inovação em comunicação já que a utilização de mapas georreferenciados promoveu uma melhor divulgação dos resultados da auditoria coordenada em áreas protegidas, diferenciando-se dos métodos tradicionais utilizados. Isso porque o Manual de Copenhagen define inovação em comunicação como a implementação de um novo método de promoção da organização ou dos seus serviços e produtos, ou novos métodos para influenciar o comportamento dos indivíduos. Estas práticas devem se diferenciar de forma significativa de métodos de comunicação já existentes na organização, como foi o caso do Indimapa.

Ademais, Koch e Hauknes (2005) ensinam que inovações devem ser novas para a própria organização, independentemente de já existirem em outras instituições. Assim, embora se utilizem ferramentas de georreferenciamento em organizações públicas e privadas, no contexto do TCU esse uso ainda não é sistemático, muito pelo contrário, ainda é bastante pontual e isolado, o que confere o caráter de inovação para aquela organização.

\subsection{Matriz de Análise}

Com o intuito de identificar os principais contrastes e semelhanças entre a auditoria em áreas protegidas e as demais auditorias coordenadas, elaborou-se uma matriz de análise com o objetivo de demonstrar as particularidades de cada fiscalização focando nas diferenças entre os trabalhos e, principalmente, nos ganhos obtidos com a nova abordagem de avaliação denominada Indimapa. Isso se deve ao fato de que a teoria da inovação prescreve que as práticas inovadoras, além do caráter do ineditismo, devem oferecer produtos ou serviços que agreguem valor e proporcionam a melhora no desempenho.

Nessa matriz de análise é apresentada a forma como foram abordados nas auditorias coordenadas e na auditoria em áreas protegidas os seguintes temas: Comunicação dos resultados; Informações georreferenciadas; Formas de monitoramento; Elementos visuais; Utilização de indicadores; Padronização e consolidação na avaliação; e Análise do arcabouço jurídico. Em seguida são elencados os produtos gerados e os benefícios para o TCU decorrentes do método Indimapa. Assim, será possível identificar a melhora no desempenho organizacional da Corte de Contas, conforme pode ser visto a seguir. 
Quadro 8 - Matriz de Análise -

Comparação entre auditorias coordenadas e a Auditoria em Áreas Protegidas

\begin{tabular}{|c|c|c|c|c|}
\hline & $\begin{array}{l}\text { Como foi feito } \\
\text { nas auditorias } \\
(2011 \text { a 2015) }\end{array}$ & $\begin{array}{l}\text { Como foi feito na } \\
\text { auditoria em áreas } \\
\text { protegidas }\end{array}$ & $\begin{array}{l}\text { Produtos } \\
\text { gerados }\end{array}$ & Benefícios esperados \\
\hline $\begin{array}{l}\text { Comunicação dos } \\
\text { resultados }\end{array}$ & $\begin{array}{l}\text { Relatório e } \\
\text { Sumário } \\
\text { Executivo }\end{array}$ & $\begin{array}{l}\text { Relatório, Sumário } \\
\text { Executivo e forma } \\
\text { alternativa de } \\
\text { divulgação }\end{array}$ & $\begin{array}{l}\text { Mapas } \\
\text { georreferenciados }\end{array}$ & $\begin{array}{l}\text { Desperta maior } \\
\text { interesse e curiosidade } \\
\text { dos leitores } \\
\text { Apresenta o resultado } \\
\text { de forma mais } \\
\text { acessível, sucinta e } \\
\text { rápida } \\
\text { Proporciona maior } \\
\text { transparência } \\
\text { administrativa e maior } \\
\text { controle social } \\
\text { (accountability) }\end{array}$ \\
\hline $\begin{array}{l}\text { Informações } \\
\text { georreferenciadas }\end{array}$ & $\begin{array}{l}\text { Não utilizada ou } \\
\text { usada de forma } \\
\text { pontual }\end{array}$ & $\begin{array}{l}\text { Georreferenciamento } \\
\text { de forma } \\
\text { sistematizada e em } \\
\text { grande volume }\end{array}$ & $\begin{array}{l}\text { Mapas } \\
\text { georreferenciados }\end{array}$ & $\begin{array}{l}\text { Facilita o processo de } \\
\text { tomada de decisão } \\
\text { estratégica por meio da } \\
\text { gestão territorial; } \\
\text { Auxilia na } \\
\text { identificação de } \\
\text { localidades } \\
\text { prioritárias; } \\
\text { Permite a } \\
\text { classificação, } \\
\text { hierarquização e } \\
\text { priorização de temas } \\
\text { (indicadores) e } \\
\text { unidades de } \\
\text { conservação; } \\
\text { Otimiza as visitas em } \\
\text { campo (áreas } \\
\text { prioritárias); e } \\
\text { Fortalece a governança } \\
\text { ambiental }\end{array}$ \\
\hline $\begin{array}{l}\text { Formas de } \\
\text { monitoramento }\end{array}$ & $\begin{array}{l}\text { Via ofício e sem } \\
\text { parâmetros claros } \\
\text { de comparação }\end{array}$ & $\begin{array}{l}\text { Via ofício com } \\
\text { comparação objetiva } \\
\text { dos Îndices e } \\
\text { indicadores; } \\
\text { Identificação de áreas } \\
\text { prioritárias }\end{array}$ & $\begin{array}{l}\text { Diagnóstico } \\
\text { comparativo }\end{array}$ & $\begin{array}{l}\text { Possibilita uma análise } \\
\text { longitudinal da } \\
\text { temática avaliada; } \\
\text { Torna o } \\
\text { monitoramento mais } \\
\text { sistemático sobre a } \\
\text { evolução dessas áreas; } \\
\text { Propicia maior } \\
\text { seletividade na escolha } \\
\text { de áreas visitadas in } \\
\text { loco }\end{array}$ \\
\hline Elementos visuais & Gráficos usuais & Gráfico de radar & $\begin{array}{l}\text { Análise } \\
\text { Multidimensional }\end{array}$ & $\begin{array}{l}\text { Permite a identificação } \\
\text { de pontos fortes e } \\
\text { fragilidades de uma } \\
\text { área protegida como de } \\
\text { todo o sistema; } \\
\text { Fornece uma } \\
\text { comparação entre } \\
\text { áreas protegidas por } \\
\text { meio da sobreposição } \\
\text { dos gráficos radar }\end{array}$ \\
\hline
\end{tabular}




\begin{tabular}{|c|c|c|c|c|}
\hline $\begin{array}{l}\text { Utilização de } \\
\text { indicadores }\end{array}$ & $\begin{array}{l}\text { Não utilizada; } \\
\text { Dificuldade de } \\
\text { acompanhar ao } \\
\text { longo do tempo e } \\
\text { medir o } \\
\text { desempenho da } \\
\text { política pública }\end{array}$ & $\begin{array}{l}\text { Estabelecimento de } \\
\text { indicadores e índices }\end{array}$ & $\begin{array}{l}\text { Critérios comuns, } \\
\text { objetivos, } \\
\text { mensuráveis e } \\
\text { comparáveis }\end{array}$ & $\begin{array}{l}\text { Propicia a } \\
\text { comparabilidade entre } \\
\text { áreas de categorias, } \\
\text { biomas, regiões e } \\
\text { países diferentes; } \\
\text { Auxilia na } \\
\text { identificação de pontos } \\
\text { comuns entre as áreas } \\
\text { melhor avaliadas; } \\
\text { Contribui para a } \\
\text { identificação de } \\
\text { aspectos comuns entre } \\
\text { as áreas pior avaliadas; } \\
\text { Permite o } \\
\text { acompanhamento do } \\
\text { desempenho da } \\
\text { política pública; } \\
\text { Possibilita a criação de } \\
\text { linha de base de } \\
\text { avaliação; } \\
\text { Permite verificar a } \\
\text { atuação do TCU (se as } \\
\text { recomendações foram } \\
\text { efetivas) }\end{array}$ \\
\hline $\begin{array}{l}\text { Padronização e } \\
\text { consolidação na } \\
\text { avaliação }\end{array}$ & $\begin{array}{l}\text { Visão parcial do } \\
\text { objeto: } \\
\text { Diagnósticos mais } \\
\text { focados e menos } \\
\text { abrangentes; } \\
\text { Somente um nível } \\
\text { de análise }\end{array}$ & $\begin{array}{l}\text { Visão sistêmica do } \\
\text { objeto e Análise } \\
\text { multinível }\end{array}$ & $\begin{array}{l}\text { Panorama } \\
\text { regional da } \\
\text { política pública }\end{array}$ & $\begin{array}{l}\text { Favorece a elaboração } \\
\text { de recomendações } \\
\text { estratégicas e } \\
\text { sistêmicas; } \\
\text { Facilita a identificação } \\
\text { de boas práticas; } \\
\text { Fornece um panorama } \\
\text { regional da política } \\
\text { pública; } \\
\text { Permite a elaboração } \\
\text { de diagnóstico em dois } \\
\text { níveis de governo } \\
\text { (estadual e federal) e } \\
\text { também internacional }\end{array}$ \\
\hline $\begin{array}{l}\text { Análise do } \\
\text { arcabouço } \\
\text { jurídico }\end{array}$ & $\begin{array}{l}\text { Análise realizada } \\
\text { de forma esparsa }\end{array}$ & $\begin{array}{l}\text { Hierarquia e } \\
\text { consolidação do } \\
\text { arcabouço-jurídico }\end{array}$ & $\begin{array}{l}\text { Quadro de } \\
\text { normativos: }\end{array}$ & $\begin{array}{l}\text { Facilita e agiliza o } \\
\text { entendimento do } \\
\text { arcabouço jurídico por } \\
\text { ser visualmente; } \\
\text { Permite a extrapolação } \\
\text { para outros normativos } \\
\text { ambientais; } \\
\text { Torna mais rápida e } \\
\text { efetiva a compreensão } \\
\text { já que, em uma única } \\
\text { visualização, permite } \\
\text { identificar lacunas, } \\
\text { usurpações, conflitos e } \\
\text { sobreposições } \\
\text { normativos }\end{array}$ \\
\hline
\end{tabular}

Fonte: elaborado pelo Autor

Após os resultados da matriz de análise, é necessário fazer algumas considerações. 
Conforme dito na seção Estudo de Caso dessa pesquisa, o Indimapa se originou de uma deliberação do Plenário do TCU para que fosse construído um instrumento de avaliação que permitisse medir, comunicar e monitorar o nível de gestão das unidades de conservação. Para atender a essa demanda, foi preciso desenvolver um método específico de avaliação que fosse apropriado à realidade do TCU e também a dos órgãos de controle estaduais e internacionais que o utilizariam posteriormente.

Nesse contexto, surgiu a necessidade de um produto customizado que possibilitasse a confecção de um diagnóstico isento e independente a respeito do patrimônio público ambiental representado pelas áreas protegidas. Esse fato vai ao encontro do que a literatura de inovação de serviços afirma, em especial a abordagem integradora, quanto às especificidades da demanda solicitada. O forte elemento de customização (GALLOUJ, 2002) é identificado em práticas inovadoras que requerem o desenvolvimento de competências específicas e que dependem das particularidades de cada produto.

Levando em conta o objetivo específico da presente pesquisa de identificar os indutores de inovação de serviços no Indimapa, pode-se afirmar que a referida ferramenta de avaliação deve ser caracterizada como uma inovação ad hoc, uma vez que a inovação adocrática, conforme Gallouj (2007), refere-se: (a) a uma solução ou a um conjunto de soluções originais de ordem organizacional, jurídica, estratégica, social etc., em resposta a um problema, ou (b) a produção de novos conhecimentos e de novas competências que se tornam reutilizáveis em outras circunstâncias. Por isso, o Indimapa deve ser visto como uma inovação ad hoc, já que nasceu da construção interativa de uma solução para um problema particular de um cliente (demanda do plenário do TCU) e decorreu de decisões da própria organização que optou, em função da relevância do tema, realizar uma avaliação dessa natureza.

Além disso, com base no esquema de vetores elaborado por Gallouj (2002, 2007), a implantação de um novo modelo de avaliação de política pública no TCU decorre do aperfeiçoamento das competências dos servidores (back-office) envolvidos com os métodos de prestação de serviços, o que impacta no serviço entregue pelo mesmo (front-office) ao seu cliente. Dadas essas características, pode-se afirmar que a implantação do Indimapa é do tipo inovação de melhoria, que consiste na "alteração, para melhor, de alguma das características do produto, sem alterar o sistema como um todo, ou seja, é o aumento da qualidade de um dos vetores e apoia-se nos efeitos da aprendizagem (individual e organizacional) presente em qualquer atividade de serviço" (GALLOUJ, 2007).

Portanto, a abordagem integradora da inovação de serviços se encaixa ao método de 
avaliação (Indimapa), já que caracteriza as especificidades tangíveis e intangíveis da inovação de serviços, sem, no entanto, desconsiderar as ideias schumpterianas. Nesse contexto, ao considerar o outro objetivo específico desta pesquisa de verificar se o Indimapa pode ser classificado como inovação de produto, inovação de comunicação, inovação organizacional e inovação de processo no âmbito do TCU, é preciso mencionar ainda que a aludida ferramenta de avaliação se apresenta como uma inovação, conforme definição da Organização para a Cooperação e Desenvolvimento Econômico.

A OCDE (2005) afirma que uma inovação é a implementação de um produto (bem ou serviço) novo ou significativamente melhorado, ou um processo, ou um novo método de marketing, ou um novo método organizacional nas práticas de negócios, na organização do local de trabalho ou nas relações externas. Além disso, o Indimapa atende a outro requisito, qual seja: para ser considerada como inovação, a medida já deve ter sido implementada, como foi o exemplo do método utilizado na auditoria de áreas protegidas. Ademais a prática inovadora deve ser nova para a instituição. Assim, a utilização de mapas georreferenciados é nova no TCU, apesar de já ser usada em outras instituições públicas e privadas.

Quanto ao último objetivo específico da presente pesquisa que buscava identificar de que forma a ferramenta de avaliação ambiental (Indimapa), caracterizada como uma inovação de serviços, melhora o desempenho organizacional do TCU, em especial quanto à comunicação dos resultados, à padronização na avaliação e ao monitoramento do objeto avaliado, faz-se necessário tecer alguns comentários. $O$ instrumento de avaliação, desenvolvido pelo TCU, vai ao encontro do esforço de modernização da administração pública e da melhoria no processo de avaliação de políticas públicas, uma vez que busca estabelecer critérios objetivos de análise por meio da utilização de indicadores. Nesse sentido, cabe destacar que se tornam ineficientes a avaliação e o acompanhamento de políticas públicas sem que sejam acompanhados dos mecanismos adequados para aferição dos resultados alcançados no âmbito do poder público.

Assim, os indicadores têm a função de estabelecer com maior clareza o que se pretende alcançar com um determinado programa de governo e o que as organizações públicas e os programas devem entregar ou produzir. Espera-se que os resultados dos indicadores reflitam o esforço dos agentes públicos, além de contemplar os requisitos de qualidade, e abranger integralmente o processo de trabalho que se busca avaliar e monitorar.

É imprescindível, portanto, para o aperfeiçoamento das ações governamentais, que o desempenho e a qualidade dos bens e serviços públicos sejam mensuráveis, o que pode ser 
feito por meio da instituição de indicadores que permitam a realização de avaliações e monitoramentos das políticas e programas de Governo.

Entretanto, essa não foi a realidade encontrada pela auditoria em áreas protegidas. $\mathrm{O}$ surgimento do Indimapa se deve também, em parte, à dificuldade de o Controle Externo medir e acompanhar sistematicamente, ao longo do tempo, o desempenho da política pública de conservação da biodiversidade (gestão de unidades de conservação), uma vez que não haviam sido estabelecidos indicadores nas auditorias anteriores. Esse quadro levava a uma outra dificuldade, qual seja: como saber se houve evolução na política pública? Daí a necessidade de definição de critérios objetivos para auxiliar a avaliação das Entidades de Fiscalização Superior (EFS).

Com a criação do Indimapa, é importante destacar que as EFS passaram a contar com um instrumento de avaliação, comunicação e monitoramento das áreas protegidas na América Latina, o qual estabeleceu uma linha de base cujos resultados poderão ser medidos e comparados futuramente quando se realizar uma nova aplicação do referido método de avaliação, propiciando uma avaliação longitudinal da referida política pública. Além disso, permite às EFS verificarem se as recomendações foram efetivas e atacaram os pontos mais relevantes.

Nesse cenário, vale dizer que o desempenho do setor público, ao ser medido e analisado de forma objetiva, possibilitará democratizar o acesso em todos os níveis da administração pública e também ao controle da sociedade (SIQUEIRA, 1990). Paralelamente, do ponto-de-vista institucional, proporcionará ferramentas que permitam gerenciar melhor os recursos disponíveis, ao mesmo tempo em que obrigará prestar contas ou informar a comunidade sobre o uso destes recursos. Além disso, sob a ótica do cidadão e de órgãos de controle, será possível exercer um melhor controle e avaliação do desempenho do gestor público (NETO, 2013).

Na mesma direção, chama-se a atenção para o fato de que as avaliações também sejam acessíveis e compreensíveis aos diferentes segmentos da sociedade, o que requer a utilização de meios alternativos e mais modernos de interação com a população, como foi o exemplo da auditoria em áreas protegidas ao utilizar mapas georreferenciados. Desse modo, a comunicação dos resultados da auditoria deve informar à sociedade acerca do desempenho da administração pública, contribuindo, dessa forma, para a responsabilização dos agentes públicos pelos resultados da ação de governo, mediante controle parlamentar e controle social (TCU, 2010). 
Portanto, a utilização de indicadores de desempenho para mensurar os resultados obtidos pelos gestores é uma técnica relacionada com o conceito de accountability (responsabilização). Nesse panorama, a accountability se apresenta como uma alternativa para a avaliação de desempenho do setor público por meio da prestação de contas. Isso porque tem-se buscado ir além da mera avaliação do desempenho financeiro, avançando em avaliações da eficiência da ação governamental, de modo que tais informações sejam úteis aos gestores públicos e os orientem a melhorar a qualidade dos serviços públicos e de seus resultados (PETERS; PIERRE, 2010).

Além disso, ao agrupar diferentes indicadores em uma mesma análise, o Indimapa contribui para a consolidação de um gama de informações que estavam dispersas, o que permite a sistematização de dados das unidades de conservação por categoria, por tema (indicador), por região geográfica, e ainda possibilita a comparação entre áreas de diferentes esferas de governo. Adicionalmente, o Indimapa auxilia na seleção de áreas a serem vistoriadas, já que é possível realizar a classificação, hierarquização e priorização das ações de controle, otimizando as visitas em campo uma vez que se sabe de antemão quais são as áreas prioritárias.

Cabe salientar que o Instituto Chico Mendes de Conservação da Biodiversidade (ICMBio), autarquia responsável pelas unidades de conservação federais, sinalizou a possibilidade de se apropriar do método criado pelo TCU para utilizar em sua própria gestão, realizando, caso entenda necessário, os ajustes, adaptações e melhorias pertinentes. Espera-se que a incorporação pelo ICMBio contribua para a melhoria da gestão do patrimônio ambiental representado pelas áreas protegidas (unidades de conservação) e para governança ambiental.

Outra vantagem é que essa ferramenta de avaliação permite um panorama regional da política pública avaliada. Têm-se dados consolidados da América Latina e para cada país, e por área protegida, o que pode ser considerado um benefício proporcionado pelas auditorias coordenadas. É preciso informar ainda que os trabalhos conjuntos, ao mesmo tempo em que favorecem o intercâmbio de experiências, a disseminação de melhores práticas de auditoria e o aperfeiçoamento de competências profissionais dos auditores, oferecem uma compreensão mais abrangente, em nível nacional e regional, da execução de políticas públicas territorialmente distribuídas e cujas atividades de formulação, planejamento e implementação estão substancialmente compartilhadas entre diferentes níveis de governo que integram os países federados.

Outro ponto que merece ser aprofundado diz respeito à comunicação dos resultados da 
auditoria. Sabe-se que as auditorias operacionais, voltadas à avaliação da eficiência, efetividade e eficácia, possuem características próprias que as diferenciam das auditorias tradicionais. Diferentemente das auditorias de regularidade, que utilizam padrões relativamente fixos, "as auditorias operacionais, devido à variedade e complexidade das questões tratadas, possuem maior flexibilidade na escolha de temas, objetos de auditoria, métodos de trabalho e forma de comunicar as conclusões de auditoria (TCU, 2010, p. 37).

Em função dessa maior discricionariedade, faz-se necessário buscar meios de divulgação adequados aos diferentes interessados, pois "de nada adianta realizar um excelente trabalho de planejamento ou de execução das auditorias, se o relatório não for capaz de comunicar sua mensagem de forma efetiva” (TCU, 2010, p. 38). Nessa linha, para que os relatórios sejam úteis e acessíveis se mostra relevante que essas publicações considerem o ponto de vista dos leitores (ISSAI 3000/5.3, 2004; BRASIL, 2001). Isso porque tais documentos visam comunicar a todos os players - academia, sociedade civil, formuladores de políticas, gestores dos três níveis de governo, outros órgãos de controle e de avaliação informações sobre desempenho no setor público.

O Manual de Anop do TCU abre a possibilidade para a utilização de novas formas de comunicação quando destaca que "documentos complementares ao relatório, como sumários executivos, notas para a imprensa e apresentação de slides, têm público mais amplo e obedecem a orientações específicas" (TCU, 2010, p. 38). Pelo que foi visto nas auditorias coordenadas, o uso de sumários executivos é uma prática bastante disseminada no âmbito do TCU. No entanto, apenas a auditoria em áreas protegidas fez uso de outras formas de divulgação, a exemplo da utilização de mapas georreferenciados.

Em função das características inovadoras identificadas na fiscalização de unidades de conservação, faz-se necessário que, a partir dos preceitos da gestão do conhecimento, a abordagem utilizada nessa auditoria seja documentada e sistematizada como forma de garantir sua institucionalização no TCU, evitando que a expertise desenvolvida nessa experiência fique restrita a determinado grupo de pessoas ou setor. Assim, entre outros pontos, será indicada no próximo capítulo do presente trabalho a institucionalização do Indimapa.

Além disso, a seguir, serão apresentadas a conclusão e as recomendações propostas, bem como será sugerida uma agenda para a realização de futuras pesquisas. 


\section{5 - CONCLUSÕES, RECOMENDAÇÕES E AGENDA DE PESQUISA}

O objetivo geral do trabalho foi analisar a relação entre inovação de serviços e desempenho organizacional no Tribunal de Contas da União (TCU) tendo como estudo de caso a ferramenta de avaliação denominada Indimapa. Trata-se de um instrumento criado para avaliar a política pública ambiental de áreas protegidas, o qual utiliza mapas georreferenciados para demonstrar o nível de gestão desses territórios protegidos.

Diante desse contexto, o Indimapa foi analisado na presente pesquisa como fenômeno da inovação de serviços, o que permitiu estudar a contribuição dessa ferramenta para o desempenho organizacional do TCU, em especial para a comunicação dos resultados, a padronização na avaliação e o monitoramento da política pública avaliada. Além disso, verificou-se se o método desenvolvido poderia ser definido como uma inovação no TCU e se encaixava-se na classificação de inovação de produto, inovação em comunicação, inovação organizacional ou inovação de processo, conforme definições do Manual de Copenhagen (OCDE, 2005).

Os resultados apontaram que, levando em consideração o referencial teórico utilizado neste trabalho, o Indimapa é uma inovação de serviços no âmbito do TCU. Isso porque o modelo apresentado se adapta ao sistema de vetores, criado por Gallouj $(2002$, 2007) para demonstrar a inovação de melhoria, espécie de inovação de serviços que, no caso do Indimapa, é o tipo que mais se adequa pela sua conceituação: "alteração, para melhor, de alguma das características do produto sem alterar o sistema como um todo", ou seja, é o aumento da qualidade de um dos vetores e apoia-se nos efeitos da aprendizagem (individual e organizacional) presente em qualquer atividade de serviço (GALLOUJ, 2007).

Ainda de acordo com a teoria, a ferramenta desenvolvida se caracteriza também por ser uma inovação ad hoc já que, conforme Gallouj e Weinstein (1997), ela deriva da construção interativa de uma solução para um problema particular de um cliente, como foi o caso do Indimapa para o TCU. Gallouj (2002) sublinha ainda a forte relação entre produtores e usuários para o desenvolvimento de produtos específicos, o que dá um caráter ainda mais relevante para a customização das soluções, aspecto também presente na construção do Indimapa.

Portanto, de acordo com Sundbo e Gallouj (1998), inovação é a mudança de um negócio através da adição de um novo elemento ou a nova combinação de antigos elementos, devendo ser um fenômeno que possa ser reproduzido. No caso do Indimapa, ainda não se havia utilizado no TCU, em um único instrumento, indicadores que demonstrassem, por meio 
de mapas georreferenciados, os resultados da avaliação do tribunal sobre determinada política pública, embora já se fizesse uso de indicadores em trabalhos anteriores. Além disso, a inovação em serviço deve ser replicável e foi possível verificar que a sistemática utilizada no Indimapa pode ser estendida para outras auditorias do TCU.

Adicionalmente, concluiu-se que o instrumento pode ser classificado como inovação em comunicação e inovação de produto, de acordo com as conceituações do Manual de Copenhagen (OCDE, 2005). Por outro lado, verificou-se, por meio das análises realizadas, que essa ferramenta não pode ser classificada como inovação organizacional, tampouco como inovação de processo.

Tão importante quanto ratificar o Indimapa como inovação é identificar os benefícios advindos dele para o desempenho organizacional do TCU. Assim, em relação à inovação em comunicação, chegou-se à conclusão de que a divulgação de resultados dos trabalhos do Tribunal, por meio de elementos visuais ou mapas georreferenciados, aumenta a compreensão dos leitores a respeito das avaliações do TCU, além de despertar o interesse dos atores envolvidos.

Nessa linha, em função da facilidade com que a informação é transmitida, fomenta-se a accountability, o que resulta na cobrança por ações governamentais com vistas a obter resultados mais positivos para a política pública de conservação da biodiversidade. Outro benefício identificado foi o estímulo à transparência administrativa do setor público, uma vez que, a partir do Indimapa, as informações sobre as áreas protegidas na América Latina foram organizadas, sistematizadas e tratadas para facilitar o entendimento do diagnóstico realizado.

Além disso, verificou-se que o Indimapa melhora o desempenho do TCU, ao tornar o monitoramento da Corte de Contas mais efetivo e com parâmetros objetivos de mensuração e de comparação, tendo em vista a utilização de índices e indicadores de gestão, o que permitirá um acompanhamento ao longo do tempo sobre a evolução do patrimônio público ambiental representado pelas áreas protegidas (APs).

Ao criar uma linha de base na avaliação da gestão de APs, é importante que se realize o monitoramento periódico e sistemático dessa política pública, por meio da atualização das informações necessárias para aplicação do Indimapa. Assim, não será preciso ir a campo a todas as áreas, por exemplo, já que haverá critérios objetivos que possibilitarão, por meio da classificação e hierarquização, definir as áreas prioritárias a serem fiscalizadas.

Isso fará com que o custo com a alocação de recursos humanos para fiscalização seja diminuído e também seja reduzido o tempo das auditorias, o que abrirá espaço para atuação 
em outras frentes e colaborará para o aumento da qualidade da atuação dos órgãos de controle. Também será possível identificar se as recomendações do TCU contribuíram para a evolução da política pública uma vez que o Indimapa permite a identificação dos pontos fortes e das fragilidades de gestão das APs, além de fornecer um panorama regional da política pública avaliada na América Latina.

Nesse sentido, concluiu-se que a implantação de modelos inovadores, a exemplo do Indimapa, segue uma vertente na administração pública que busca a eficiência e eficácia dos processos organizacionais e um incremento na comunicação dos resultados do setor público. Com efeito, no contexto do TCU, espera-se que a adoção e a replicação de práticas inovadoras sejam acompanhadas de ações visando o fortalecimento da imagem da instituição e o aperfeiçoamento de suas atividades.

Quanto às limitações do presente trabalho, pode-se mencionar a ausência de critérios objetivos que permitissem a comparação do desempenho institucional antes e após a implementação do Indimapa, o que impediu identificar quantitativamente a melhora no desempenho do TCU.

É preciso destacar ainda que, em função das características de um Curso de Mestrado Profissional em Administração, o estudo ora realizado deve buscar apontar também recomendações de interesse à instituição à qual o pesquisador está vinculado. Desse modo, a seguir são apresentadas sugestões ao TCU para que avalie a oportunidade e conveniência de adotar medidas no sentido de: a) expandir o modelo Indimapa para outras áreas, por meio de testes piloto; b) sistematizar e documentar o processo de auditoria coordenada em áreas protegidas; c) aprimorar os mecanismos de divulgação dos resultados das avaliações realizadas pelo TCU; d) institucionalizar o uso de ferramentas georreferenciadas para as atividades de controle externo, em especial, para as auditorias; e) estimular a incorporação, pelo setor responsável por metodologias no TCU, da sistemática adotada durante o processo de auditoria coordenada em áreas protegidas.

Já em relação à agenda de pesquisa para futuros trabalhos, sugere-se que a ferramenta desenvolvida pelo TCU (Indimapa) seja cotejada com outros modelos de avaliação existentes em outros órgãos de controle brasileiros ou de outros países, permitindo a realização de estudos comparados internacionais.

Também se propõe que seja feito estudo longitudinal no âmbito do TCU para avaliar o impacto da segunda rodada de aplicação do Indimapa, de forma a verificar a contribuição da ferramenta para o alcance da missão do tribunal já que um dos objetivos institucionais 
definidos no Mapa Estratégico do TCU para o período de 2015-2021 é contribuir com o aperfeiçoamento da administração pública.

Nessa linha, o Indimapa busca, portanto, aprimorar a governança e a gestão em organizações e políticas públicas, além de fomentar a transparência na administração pública. Isso porque ele permitiu a realização de um diagnóstico sistêmico na área ambiental, ademais de estimular o monitoramento e a avaliação do desempenho pela administração pública.

Afora isso, a ferramenta favoreceu o relacionamento institucional, na medida em que se intensificou o intercâmbio nacional e internacional para compartilhamento de melhores práticas de auditoria entre diferentes outros órgãos de controle, o que também culminou com o aperfeiçoamento da comunicação do TCU com as diversas partes interessadas.

Tudo isso foi possível levando em conta o binômio Gestão e Inovação, por meio do aprimoramento da gestão do conhecimento e o uso da TI como instrumento de inovação para o controle. Assim, espera-se que, a partir da identificação e análise das características do Indimapa, o presente trabalho contribua para os estudos em inovação de serviços no setor público e, consequentemente, para o aprimoramento do desempenho organizacional do TCU.

Portanto, o Indimapa vai ao encontro da moderna atribuição incumbida aos órgãos de controle que, por meio de mecanismos inovadores, devem atuar de forma a contribuir com o aperfeiçoamento da administração pública e, principalmente, com a melhoria da qualidade dos serviços prestados à sociedade. 


\section{6 - REFERÊNCIAS BIBLIOGRÁFICAS}

AMARAL, Cristiana Alves do. Gestão por competências no ministério da educação: Um estudo de caso à luz da inovação em serviços. Dissertação de Mestrado. Universidade de Brasília - UnB. Brasília, 2013.

BARDIN, Laurence. Análise de conteúdo. Lisboa: Edições 70, 1977.

BARRAS, R. Towards s theory of innovation in services. Research Policy, v.15, p. 161-174, 1986.

BIRKINSHAW, Julian; HAMEL, Gary; MOL, Michael J. Management innovation. Academy of Management Review, v. 33, n. 4, p. 825-845, 2008.

BILDERBEEK, R. et al. Innovation in Services. Oslo, Noruega, (SI4S - Syntehesis Paper, n. 3), 1998.

BLOCH, C. Copenhagen manual: towards a conceptual framework for measuring public sector innovation. Copenhagen: MEPIN, 2010a.

BLOCH, C. Measuring public innovation in the Nordic Countries: final report. Copenhagen: MEPIN, 2010b.

BLOCH, C.; BUGGE, M. Public sector innovation - From theory to measurement. Structural Change and Economic Dynamics, 27, 133-145, 2013.

BORINS, S. Encouraging innovation in the public sector. vol. 2, n. 3. 2001. p. 310319. Disponível em: $<$ http://www.emeraldinsight.com/journals.htm?articleid=883940 $>$.

BRANDÃO, Soraya Monteiro; FARIA, Maria de Fátima Bruno. Inovação no setor público: análise da produção científica em periódicos nacionais e internacionais da área de administração. Rev. Adm. Pública — Rio de Janeiro 47(1):227-248, jan./fev. 2013.

CARAYANNIS, Elias G.; GONZALEZ, Edgar; WETTER, John J. The nature and dynamics of discontinuous and disruptive innovations from a learning and knowledge management perspective. In: SHAVININA, Larisa V. (Org.). The international handbook on innovation. Oxford: Elsevier Science, 2003. p. 115-138.

CASTRO-LUCAS, Cristina de Souza. A Relação entre Inovação e o Desempenho Internacional de Atividades de Serviços em Empresas. Tese de Doutorado. Universidade de Brasília, 2011.

CHESBROUGH, Henry W. Toward a new science of services, Harvard Business Review, Breakthrough Ideas, Vol. 83 №. 2, pp. 43-44. 2005.

COELHO JR., F. A. Suporte à aprendizagem, satisfação no trabalho e desempenho: um estudo multinível. 2009. 283 f.; Tese (doutorado) - Universidade de 
Brasília, Instituto de Psicologia, Programa de Pós-Graduação em Psicologia Social, do Trabalho e das Organizações, 2009.

COSTA, Frederico Lustosa; CASTANHAR, José Cezar da. Avaliação de programas públicos: desafios conceituais e metodológicos. Rio de Janeiro 37(5):969-92, Set./Out. 2003.

CRESWELL, J. W. Projeto de pesquisa: métodos qualitativo, quantitativo e misto. 3.ed. Porto Alegre: Artmed/Bookman, 2010.

DANTAS, Aline Soares; QUEIROZ, Fernanda Cristina Barbosa Pereira; QUEIROZ, Jamerson Viegas. Gestão de processos e avaliação de desempenho no setor público brasileiro: um estudo de caso em uma instituição de ensino superior pública. $X$ Colóquio Internacional sobre Gestão Universitária na América do Sul, 2010.

FARIA, Carlos Aurélio Pimenta de. A Política da Avaliação de Políticas Públicas. 2005 RBCS Vol. 20 nº. 59 outubro/2005.

FARO, Eduardo Soares da Costa; AMORIM, Maria Cristina Sanches; TREVISAN, Leonardo; JUNQUEIRA, Luciano A. Prates. Âncoras de carreira e transformações no modelo de administração: estudo de caso do Tribunal de Contas da União (TCU). Cadernos EBAPE. BR, v. 8, n 4, artigo 9, Rio de Janeiro, Dez. 2010 p. 710-733.

FERRAREZI, Elisabete; AMORIM, Sonia. Concurso inovação na gestão pública federal: análise de uma trajetória (1996-2006). Cadernos Enap, Brasília, n. 32, p. 1-53, 2007.

FERNÁNDEZ, Sergio; WISE, Lois R. An exploration of why public organizations “ingest” innovations. Public Administration Journal, v. 88, n. 4, p. 979-998, 2010.

Gadrey, J., Gallouj, F. and Weinstein, O. (1995) New Modes of Innovation: How Services Benefit Industry, International Journal of Service Industry Management, Vol. 6 No. 3, pp. 4-16.

GALLOUJ, Faïz. Innovation in the service economy: the new wealth of nations. Cheltenham, UK: Edward Elgar Publishing Limited, 2002.

GALLOUJ, Faiz. Economia da inovação: um balanço dos debates recentes. In: BERNARDES, Roberto; ANDREASSI, Tales (Org). Inovação em serviços intensivos em conhecimento. São Paulo: Saraiva, 2007. cap 1.

GALLOUJ, F.; SAVONA, M. Innovation in services: a review of the debate and a research agenda. Journal of Evolutionary Economics, v. 19, n. 2, p. 149-172, 2009.

GALLOUJ, Faïz; WEINSTEIN, Olivier. Innovation in services. Research Policy, n. 
26, p. 537-556, 1997.

GESPUBLICA. Melhoria da gestão pública por meio da definição de um guia referencial para medição do desempenho da gestão, e controle para o gerenciamento dos indicadores de eficiência, eficácia e de resultados do programa nacional de gestão pública e desburocratização. Brasília, 2010.

GOMES, Adalmir de Oliveira; GUIMARAES, Tomás de Aquino. Desempenho no Judiciário: conceituação, estado da arte e agenda de pesquisa. Rev. Adm. Pública, Rio de Janeiro, v. 47, n. 2, p. 379-401, Apr. 2013 .

GRATERON, Ivan Ricardo Guevara. Auditoria de Gestão: Utilização de Indicadores de Gestão no Setor Público. Caderno de Estudos, São Paulo, FIPECAFI, n²1 - Maio a Agosto/1999.

GUZMÁN, Miguel D. A auditoria comprehensiva: un moderno concepto en la auditoría, México: 1991.

HAUKNES, J. Services in innovation - Innovation in services. Step report, n.13, 1998.

HALVERSEN, T. On innovation in the public sector. Oslo: Publin/NIFU/STEP. 2005 .

HEDLER, Helga Cristina e TORRES, Cláudio Vaz. Meta-avaliação de Auditorias de Natureza Operacional do Tribunal de Contas da União. RAC, Curitiba, v. 13, n. 3, art. 7, p. 468-486, Jul./Ago. 2009.

ISIDRO-FILHO, Antonio. Adoção de inovações apoiadas em tecnologias de informação e comunicação, formação de competências e estratégias de aprendizagem em hospitais. Tese de Doutorado. Universidade de Brasília, 2010.

ISIDRO-FILHO, Antonio; FERREIRA. Vicente da Rocha Soares; TETE, Marcelo Ferreira; SOUSA, Marcos de Moraes. Inovação no Setor Público Federal no Brasil na Perspectiva da Inovação em Serviços. Enanpad. Rio de Janeiro. XXXVIII Encontro Anpad, 2014.

JANUZZI, P. Indicadores para diagnóstico, monitoramento e avaliação de programas sociais no Brasil. Revista do Serviço Público. Brasília, 2005.

JUNIOR, Pedro Carlos Resende; GUIMARÃES, Tomás de Aquino. Inovação em Serviços: o estado da arte e uma proposta de agenda de pesquisa. Revista Brasileira de Gestão de Negócios, 2012.

KETTL, Donald F. (1996) A revolução global: reforma da administração do setor 
público. In: BRESSER-PEREIRA, Luiz Carlos; SPINK, Peter. Reforma do Estado e administração pública gerencial. Rio de Janeiro: FGV, 1998.

KLEMENT, Claudia Fernanda Franceschi. Inovação em Serviços: Análise Multicasos em uma Organização Hoteleira. Tese de Doutorado. Universidade de São Paulo, 2007.

KOCH, P.; CUNNINGHAM, P.; SCHWABSKY, N.; HAUKNES, J. Innovation in the public sector - summary and policy recommendations. NIFU STEP, Oslo, 2006.

LIMA, Luiz Henrique Moraes de. O Tribunal de Contas da União (TCU) e a gestão ambiental brasileira: experiência recente. Cad. EBAPE.BR, Rio de Janeiro, v. 3, n. 3, 2005.

LOUREIRO, M. R.; Rogério Arantes; Couto, Cláudio; TEIXEIRA, M. A. C. Controles democráticos sobre a administração pública no Brasil: Legislativo, Tribunais de Contas, Judiciário e Ministério Público. Burocracia e política no Brasil: desafios para a ordem democrática no século XXI. $1^{\text {a }}$ ed. Rio de Janeiro: FGV, 2010, v. 1, p. 1-32.

MEIRELLES, Durval Corrêa. A inovação e aprendizado coletivo: interação e cooperação de empresas de base tecnológica em incubadoras de empresas. Anpad, 2008.

MPOG, Secretaria de Planejamento e Investimentos Estratégicos. Indicadores de Programas: Guia Metodológico. 2010.

MOREIRA, Marina; GUIMARÃES, Tomas; CASTRO-LUCAS, Cristina de Souza; ALBUQUERQUE, Pedro. Service Innovation as a research theme: where 30 years of work have brought us? XXIV International RESER Conference, 2014.

MULGAN, Geoff; ALBURY, David. Innovation in the public sector. Londres, v. 1.9, 2003.

NATIONAL AUDIT OFFICE. Achieving innovation in central government organization. Londres, 2006.

NETO, José Arimathea Valente. Análise comparativa entre os modelos do Tribunal de Contas da União e do Ministério do Planejamento, Orçamento e Gestão para elaboração de indicadores de desempenho. Artigo apresentado ao Instituto Serzedello Corrêa, 2013.

OCDE. Manual de Oslo. Diretrizes para coleta e interpretação de dados sobre inovação. 3. ed. Brasília: Finep, 2005.

OLIVEIRA, Luiz Guilherme de. Inovação no Setor Público: uma reflexão. Centro de Estudos Avançados de Governo e de Administração Pública - CEAG. Série Textos de Discussão CEAG/UnB, 002/14. Brasília, 2014. 
PETERS, G. ; PIERRE, J. (orgs.) Como Avaliar o Desempenho e a Efetividade do Setor Público (Carolyn Heinrich). Administração Pública: coletânea. Enap. Brasilia/DF, 2010.

PHILIPPE, J; LÉO, P-Y. Innovation and Internationalization: a dynamic coupling for business-to-business services. In: Gallouj, F; Djellal, F. The Handbook Of Innovation And Services: A Multi-disciplinary Perspective, Edward Elgar Publishing, 2010.

RAMOS, Marília Patta; SCHABBACH, Letícia Maria. O estado da arte da avaliação de políticas públicas: conceituação e exemplos de avaliação no Brasil. Rev. Adm. Pública, Rio de Janeiro, v. 46, n. 5, Oct. 2012.

RICHARDSON, R. J. Pesquisa social: métodos e técnicas. 3 ed. São Paulo. Atlas, 2010 .

ROGERS, EVERETT M \& SHOEMAKER, FLOYD F. Communication of Innovations: A Cross-Cultural Approach (2nd ed.). New York: The Free Press, 1971.

SALGE, T. A Behavioral Model of Innovative Search: Evidence from Public Hospital Services. Journal of Public Administration Research and Theory. Apr. 2010, p. 181210.

SAlAZAR, M.; HOLBROOK, A. A Debate on Innovation Surveys. Science and Public Policy, v. 31, n. 4, England: Beech Tree Publishing, Aug. 2004, p. 254-266.

SARAVIA, Enrique. Políticas públicas Coletânea - Volume 1 Cadernos da Enap. Introdução à teoria da política pública, 2006.

SCHUMPETER, J. A. Teoria do Desenvolvimento Econômico: uma investigação sobre lucros, capital, crédito, juro e o ciclo econômico. São Paulo: Nova Cultura, 1987.

SCHUMPETER, Joseph. A teoria do desenvolvimento econômico. São Paulo: Abril Cultural, 1982.

SIQUEIRA, Moema Miranda de. Eficácia da administração pública: imposição democrática. Rev. adm. empres., São Paulo, v. 30, n. 1, Mar. 1990.

SUNDBO, Jon. Innovation and strategic reflexivity: an evolutionary approach applied to services. In: SHAVININA, Larisa V. (Org.). The International Handbook on Innovation. Oxford: Elsevier Science, 2003. p. 97-114.

SUNDBO, J. e GALLOUJ. F. (1998) Innovation in services. Services in innovation, innovation in services.

TCE-SP, Índice de efetividade da gestão municipal. São Paulo, 2014.

TCU, Manual de Auditoria Operacional. Portaria-SEGECEX 4/2010. 
Norma de Auditoria do Tribunal de Contas da União. Anexo da Portaria - TCU 280/2010, alterada pela Portaria - TCU 168/2011.

, Técnica de Auditoria - Indicadores de Desempenho e Mapa de Produtos, 2000.

TIROLE, J. The Theory of Industrial Organization, MIT Press, 1995.

TREVISAN, Andrei Pittol e BELLEN, Hans Michael Van. Avaliação de políticas públicas: uma revisão teórica de um campo em construção. RAP - Rio de Janeiro 42(3):529-50, maio/jun. 2008.

VALLE, André Guimarães Resende Martins do. Análise de fatores determinantes no desempenho de municípios brasileiros. Dissertação de mestrado. Universidade de Brasília UnB. Brasília, 2011.

VIGODA-GADOT, Eran; SHOHAM, Aviv; SCHWABSKY, Nitza e RUVIO, Ayalla. Public sector innovation for Europe: a multinational eight-country exploration of citizen's perspectives. Public Administration Journal, v. 86, n. 2, p. 307-329, 2008.

YIN, Robert K. Estudo de Caso, Planejamento e Métodos, Porto Alegre: $4^{\mathrm{a}}$. ed. Editora Bookman, 2010.

WALKER, Richard. M.; DAMANPOUR, Fariborz.; DEVECE, Carlos. A. Management Innovation and Organizational Performance: The Mediating Effect of Performance Management. Journal of Public Administration Research and Theory, Aug. 2010, p. 367-386.

WALKER, Richard M. An empirical evaluation of innovation types and organizational and environmental characteristics: towards a configuration framework. Journal of Public Administration Research and Theory, v. 18, n. 4, p. 591-615, 2007.

WARIN, P. (Dir.). Quelle modernisation des services publics: les usagers au coeur des réformes. Paris: La Découverte, 1997. 


\section{APÊNDICES \\ INSTRUMENTOS DE COLETA DE DADOS}




\section{ROTEIRO DE ENTREVISTA}




\section{BRIEFING}

Prezado(a) colega,

Sou aluno do mestrado em Administração Pública pela Universidade de Brasília - UnB e gostaria de contar com sua colaboração na pesquisa que estou desenvolvendo.

É muito simples. Basta responder o roteiro de entrevista, cujo objetivo é levantar informações sobre "Inovação nos Processos de Trabalho das Auditorias do TCU”.

O tempo estimado para aplicação do roteiro de entrevista é de, no máximo, 60 minutos.

Destaco que não existe resposta certa ou errada e que sua avaliação deve refletir, com honestidade, o que você pensa sobre cada pergunta.

Informo, por último, que os entrevistados não serão identificados.

Agradeço desde já a sua participação.

\section{Carlos Eduardo Lustosa da Costa}

Auditor Federal de Controle Externo

SecexAmbiental

carloslustosa@tcu.gov.br 
Universidade de Brasília - UnB

Faculdade de Economia, Administração e Contabilidade - FACE

Programa de Pós-Graduação em Administração - PPGA

Mestrado Profissional em Administração - MPA

Data da entrevista:

Horário:

Local:

Tempo no TCU?

\begin{tabular}{|l|l|l|}
\hline ( ) até 3 anos & $(\quad$ ) 3 a 6 anos & ( ) 6 a 10 anos \\
\hline$(\quad) 10$ a 15 anos & $(\quad$ ) 15 a 20 anos & ( ) Mais de 20 anos \\
\hline
\end{tabular}

Ao responder as próximas perguntas, leve em conta sua experiência profissional no TCU e também o seu conhecimento sobre a auditoria coordenada em áreas protegidas - unidades de conservação.

Considere os produtos elaborados nessa auditoria, em especial, o Indimapa (método de avaliação da gestão de áreas protegidas que utiliza mapas georreferenciados).

Vamos começar? 
Universidade de Brasília - UnB

Faculdade de Economia, Administração e Contabilidade - FACE

Programa de Pós-Graduação em Administração - PPGA

Mestrado Profissional em Administração - MPA

\footnotetext{
Na sua opinião, a inovação é uma característica importante para o Controle Externo?

1

Como a inovação pode contribuir para a melhoria das auditorias do TCU?
}

2 A utilização de mapas georreferenciados em auditorias do TCU é frequente?

Quais são as vantagens do georreferenciamento? 
\begin{tabular}{|l|l}
\hline 3 & A utilização de mapas georreferenciados ou instrumentos de georreferenciamento facilita o monitoramento pelo TCU?
\end{tabular}

$4 \quad$ A comunicação dos resultados da auditoria por meio de mapas é mais acessível para a sociedade? Por quê? 
5 O Indimapa contribui para a padronização dos resultados de trabalhos coordenados?

O fato de ter índices e indicadores contribui para a consolidação dos resultados?

\begin{tabular}{l|l}
6 & Quais são as principais características do Gráfico de Radar/Aranha?
\end{tabular} 
\begin{tabular}{|l|l}
\hline & Quais são as principais características do Quadro de Normativos? Já tinha vista um produto como esse?
\end{tabular}

8 A metodologia utilizada na auditoria em áreas protegidas (Indimapa) pode ser aplicada em outras auditorias TCU? Como? 
Universidade de Brasília - UnB

Faculdade de Economia, Administração e Contabilidade - FACE

Programa de Pós-Graduação em Administração - PPGA

Mestrado Profissional em Administração - MPA

\section{INOVAÇÃO - DEFINIÇÕES}

9 Inovação: implementação de uma mudança significativa na forma como a organização opera ou nos produtos que fornece.

O Indimapa (Avaliação da Implementação e da Gestão de Áreas Protegidas) é uma inovação no TCU?

( ) SIM

( ) NÃO

10

Inovação de produto: introdução de um serviço ou bem que é novo ou significativamente melhorado em comparação com os serviços existentes ou bens da organização.

O Indimapa é uma inovação de produto no TCU?

( ) SIM

( ) NÃO

11

Inovação em comunicação: implementação de um novo método de promoção da organização ou dos seus serviços e produtos, ou novos métodos para influenciar o comportamento dos indivíduos ou outros.

O Indimapa é uma inovação em comunicação no TCU?

( ) SIM

( ) NÃO

12

Inovação organizacional: implementação de um novo método para a organização ou gestão do trabalho que difere significativamente dos métodos existentes na organização.

O Indimapa é uma inovação organizacional no TCU? 
Universidade de Brasília - UnB

Faculdade de Economia, Administração e Contabilidade - FACE

Programa de Pós-Graduação em Administração - PPGA

Mestrado Profissional em Administração - MPA

\begin{tabular}{|l|l|}
\hline & $\begin{array}{l}\text { ( ) SIM } \\
\text { ( ) NÃO }\end{array}$ \\
\hline 13 & $\begin{array}{l}\text { Inovação de processo: implementação de um método para a produção e fornecimento de bens e serviços que é novo ou significativamente } \\
\text { melhorado em comparação com os processos existentes na organização. }\end{array}$ \\
\hline $\begin{array}{l}\text { O Indimapa é uma inovação de processo no TCU? } \\
\text { ( ) SIM } \\
\text { ( ) NÃO }\end{array}$ \\
\hline
\end{tabular}

Gostaria de fazer algum comentário?

Muito obrigado. 